\title{
Garwascy herbu Grzymała w XV-XVII wieku Przyczynek do dziejów i genealogii rodu
}

Garwascy herbu Grzymała (bez męża zbrojnego) to stara, zamożna i zasłużona rodzina mazowiecka, która apogeum swojego znaczenia osiagnęła w dobie panowania Zygmunta III Wazy, wydając w tym czasie dwóch kasztelanów płockich. Sprawowanie przez przedstawicieli tej rodziny jednego $z$ ważniejszych urzędów senatorskich na Mazowszu pozwala zaliczyć Garwaskich do ówczesnej elity politycznej tak w skali prowincji wielkopolskiej, jak i całej Korony. Warto w tym miejscu zwrócić również uwagę na to, że czterech najwybitniejszych członków tego rodu, żyjaccych w XVI i XVII w., doczekało się zwięzłych biogramów w Polskim słowniku biograficznym. Niemniej jednak wypada od razu zaznaczyć, że dzieje tej rodziny były dotad stosunkowo słabo rozpoznane ${ }^{1}$. Brakuje rzetelnego żytnej.

* Wydział Filozoficzno-Historyczny, Instytut Historii, Katedra Historii Nowo-

1 Por. T. Gi e m m a, Garwaski Hieronim, [w:] Polski słownik biograficzny [dalej: PSB], t. VII, Kraków 1948-1958, s. 290-291; A. P r zy b o ś, Garwaski Piotr, [w:] ibidem, s. 291; K. Le p szy, Garwaski Stanisław, [w:] ibidem, s. 291-292; H. B a ry cz, Garwaski Stanisław, [w:] ibidem, s. 292; K. N i e s i e c ki, Herbarz polski [dalej: Niesiecki, Herbarz], wyd. J.N. Bobrowicz, t. IV, Lipsk 1839, s. 76-77; A. B o n i e c k i, Herbarz polski [dalej: B o n i e c k i, Herbarz], t. V, Warszawa 1902, s. 378-379; S. U ru ski, A.A. Ko s iński, A. Włod ar ski, Rodzina. Herbarz szlachty polskiej [dalej: U r u s k i, Herbarz], t. IV, s. 103-104. Por. też E. O paliński, Rodziny wielkosenatorskie $w$ Wielkopolsce, na Kujawach i na Mazowszu za Zygmunta III. Podstawy karier, Warszawa 2007, passim; oraz K. P ełk a, Kariera braci Garwaskich, „Tygodnik Ciechanowski” 2007, wydanie internetowe z 17 III; ostatnio zaś P. G aw ro n, A. M o n i u s z k o, Paweł Garwaski a „przygotowanie zawodowe” sędziów niższych sadów szlacheckich u schyłku XVI wieku, „Krakowskie Studia z Historii Państwa i Prawa” 2015, t. VIII, nr 2, s. $133-157$. 
opracowania genealogii rodu, a stosunkowo liczne, choć bardzo rozproszone wzmianki o Garwaskich zawarte w dotychczasowej literaturze przedmiotu pełne są różnego rodzaju błędów, przeinaczeń i nieścisłości. Celem niniejszego opracowania jest więc przedstawienie uzupełnień do genealogii omawianego rodu, zbilansowanie jego dokonań w XV, XVI i XVII stuleciu oraz przypomnienie postaci najwybitniejszych przedstawicieli tej rodziny.

Protoplasta Garwaskich był żyjący na przełomie XIII i XIV w. kasztelan wyszogrodzki Mikołaj. W czerwcu 1319 r. otrzymał on od księcia płockiego Wacława (Wańka) nadanie na wieczność kilku wsi, które trzymać miał iure hereditario $z$ prawem przekazania ich swoim legalnym spadkobiercom. Książęca darowizna obejmowała Wkrę (cum omnis iure ducali), Białobrzegi ( $z$ uwolnieniem od jurysdykcji kasztelańskiej) oraz Gerważe (Garwarz), Wyszkowo, Dąbek i Modłę. Na mocy osobnego przywileju książę Wacław nadał też Mikołajowi w dziedziczne posiadanie wieś Miszewo nad rzeka Mołtawa, uwalniając przy tej okazji również te dobra od jurysdykcji swoich urzędników i zezwalając kasztelanowi na lokowanie $\mathrm{w}$ nich miasta lub wsi na prawie niemieckim. Dobra nadane kasztelanowi wyszogrodzkiemu w 1319 r. nie stanowiły zwartego kompleksu majątkowego. Co prawda wsie Wkra, Gerważe (Garwarz), Modła, Dąbek, a zapewne i Wyszkowo leżały na Zawkrzu, w granicach kasztelanii wyszogrodzkiej, ale dwie pierwsze usytuowane były w okolicach Glinojecka, a trzy pozostałe nieopodal Mławy. Wioski Białobrzegi i Miszewo leżały natomiast na terenie kasztelanii płockiej, w niezbyt dużej odległości na południowy wschód od stolicy księstwa - pierwsza nad Wisłą, a druga niedaleko Bodzanowa ${ }^{2}$.

2 Nazwy miejscowości wymienionych w przywilejach księcia Wacława z $1319 \mathrm{r}$. odczytywano pierwotnie jako: Wkra, Białobrzegi, Gerwazy (Gerważe), Wyszkowo (Wyskowo, Wiskowo), Dąbek i Modlany. Por. Kodeks dyplomatyczny Księstwa Mazowieckiego [dalej: KM], wyd. J.T. Lubomirski, Warszawa 1863, nr LIII, LIV; F. Pi e k o s iń s k i, O dynastycznem szlachty polskiej pochodzeniu, Kraków 1888, s. 133-134; J. P i ęt k a, Geneza mazowieckiej elity feudalnej $i$ jej stan $w$ pierwszym okresie udzielności księstwa (1138-1371), „Rocznik Mazowiecki” 1979, t. VII, s. 51-52 (tu informacja, że kasztelan wyszogrodzki Mikołaj był przodkiem Mniszewskich h. Grzymała. Brak natomiast stwierdzenia, że jego potomkami byli również Garwascy); Słownik geograficzny Królestwa Polskiego i innych krajów słowiańskich [dalej: SGKP], wyd. B. Chlebowski, F. Sulimierski i W. Walewski, t. XV, cz. 2, Warszawa 1902, s. 506, 693. Prawidłowa identyfikacja nazw wiosek wspomnianych w przywileju księcia Wacława z 1319 r. por. Słownik historyczno-geograficzny województwa płockiego $w$ średniowieczu [dalej: SHG-Płock], oprac. 
O synach i wnukach kasztelana wyszogrodzkiego Mikołaja nic nie wiadomo. Na początku XV w. pojawiają się natomiast w źródłach dwaj niewatpliwi potomkowie kasztelana, których zaliczyć wypada do pokolenia jego prawnuków ${ }^{3}$. Byli to rodzeni bracia: Mikołaj Sowa $z$ Miszewa i Krawięczyna (zm. 1442), kasztelan wyszogrodzki, oraz Filip z Małoszewa i Miszewa (zm. 1442), podczaszy płocki. Bezpośrednim przodkiem Garwaskich był młodszy $z$ nich Filip. Warto jednak słów kilka poświęcić również przedstawicielom starszej gałęzi Grzymalitów z Miszewa, gdyż to głównie ich kosztem piętnastowieczni przodkowie późniejszych Garwaskich powiększyli $z$ czasem swoje majętności. Na podstawie zachowanych wzmianek źródłowych możemy dokładnie określić stan posiadania kasztelana wyszogrodzkiego w chwili jego śmierci. W 1443 r. trzej synowie Mikołaja Sowy z Miszewa i Krawięczyna - Andrzej, Mikołaj i Zdziesław (notabene wszyscy oni pisali się już tylko z Krawięczyna) dokonali bowiem podziału dóbr po ojcu. Dwaj starsi - Andrzej i Mikołaj - wzięli Wkrę i Krawięczyn, a najmłodszy Zdziesław - Mchowo i Nową Wieś ${ }^{4}$.

Nieco skromniej prezentował się majątek podczaszego płockiego Filipa (zm. 1442), urodzonego najpewniej u schyłku XIV w. W jego posiadaniu znajdowały się bowiem początkowo jedynie wsie Garwarz i Małoszewo. W roku 1426 późniejszy podczaszy płocki (od 1435 r.) odnotowany został w źródłach właśnie jako Filip z Małoszewa, gdzie miał zapewne rezydencję. Około 1420 r. nabył on od spadkobierców Niemierzy ze Szczawina h. Prawdzic lesiste tereny koło Gąbina w ziemi gostynińskiej, gdzie kilka lat później osadził

A. Borkiewicz-Celińska, Wrocław-Warszawa 1980-2000, s. 9, 53, 193, 202 i 330. Szerokie omówienie nadań Wańka płockiego na rzecz kasztelana wyszogrodzkiego Mikołaja por. K. P a c u s k i, Możnowładztwo i rycerstwo ziemi gostynińskiej w XIV i XV wieku. Studium z dziejów osadnictwa i elity władzy na Mazowszu średniowiecznym, Warszawa 2009, s. 430-431 (tu także stwierdzenie, że na obszarze przynależnym do istniejącej już w 1319 r. osady Miszewo lokowano później 4 wsie - Miszewo Garwaskie, Miszewo Cztanowe, Małoszewo i Krawięczyn).

${ }^{3}$ Nie znamy oczywiście dokładnych dat życia interesujacych nas postaci. Zakładam jednak, że kasztelan wyszogrodzki Mikołaj urodził się nie później niż w 1290 r. Z kolei starszy z braci z Miszewa - Mikołaj Sowa - został odnotowany jako właściciel tej wioski w roku 1414. Urodził się więc zapewne w ostatniej dekadzie XIV stulecia. Różnica około 100 lat między narodzinami obu Mikołajów sugeruje, że drugi był raczej prawnukiem niż wnukiem pierwszego.

4 Por. SHG-Płock, s. 193, 330; oraz Słownik historyczno-geograficzny ziemi wyszogrodzkiej $w$ średniowieczu [dalej: SHG-Wyszogród], oprac. A. Wolff, A. Borkiewicz-Celińska, Wrocław 1971, s. 29. 
wieś Rybie (w 1436 r. jej mieszkańcy korzystali jeszcze $z$ wolnizny). W 1439 r. przejął natomiast od starszego brata, kasztelana wyszogrodzkiego Mikołaja Sowy wieś Miszewo, z której odtąd zaczął się pisać. Był człowiekiem stosunkowo zamożnym, skoro wkrótce po nabyciu Miszewa mógł dodać córce do wypłaconego wcześniej posagu 100 grzywien krakowskich. Warto w tym miejscu odnotować, że w rękach Mikołaja Sowy oraz Filipa $z$ Miszewa przez cały okres ich życia pozostawały trzy (Wkra, Garwarz i Miszewo) spośród siedmiu wiosek wymienionych w przywilejach księcia Wacława dla kasztelana wyszogrodzkiego Mikołaja z 1319 r. Zmarły przed 5 kwietnia 1442 r. podczaszy płocki Filip z Miszewa h. Grzymała pozostawił po sobie córkę Katarzynę, żonę Andrzeja z Koziebród, podczaszego dworu książąt płockich, która w 1439 r. skwitowała ojca $z$ zadośćuczynienia za ojcowiznę, oraz jedynego syna Jana ${ }^{5}$.

Jan $z$ Miszewa h. Grzymała (zm. 1471), syn Filipa, podczaszego płockiego, odnotowywany jest w źródłach w latach 1440-1471. Urodził się zapewne w drugim dziesięcioleciu XV w. Był już pełnoletni w 1440 r., kiedy w imieniu ojca przedstawiał przywilej księcia Wacława $z 1319$ r., na mocy którego potomkowie kasztelana wyszogrodzkiego Mikołaja uzyskali prawo dziedzicznego władania wymienionymi w tym dokumencie dobrami. W $1442 \mathrm{r}$. Jan odziedziczył wszystkie majątki należące wcześniej do jego ojca, więc wsie Miszewo (dziś Miszewko Garwackie) i Małoszewo w ziemi płockiej (parafia Bodzanów), Garwarz (dziś Garwarz Stary i Nowy) w ziemi zawkrzeńskiej (parafia Glinojeck) oraz Rybie w ziemi gostynińskiej (parafia Gąbin). W tym samym roku Jan $z$ Miszewa, syn zmarłego podczaszego Filipa, został odnotowany jako dworzanin księcia płockiego Włodzisława I, który obdarzył go wówczas przywilejem zwalniającym jego dom w Płocku od sądownictwa miejskiego, wszelkich czynszów i ciężarów oraz zezwalającym na prowadzenie tam wyszynku piwa i handlu towarami niewytworzonymi w mieście. Jan $z$ Miszewa konsekwentnie zabiegał o powiększenie swoich dóbr ziemskich, przeprowadzając szereg transakcji

5 Por. SHG-Płock, s. 144, 185, 193. Dodajmy tu również, że najpóźniej w ostatniej ćwierci XIV lub też $\mathrm{w}$ początkach następnego stulecia doszło do podziału włości miszewskiej, $z$ której odpadła wioska Miszewo Cztanowe (dziś Stanowo Dolne). Dziedzicami tej osady byli niewattpliwi potomkowie kasztelana wyszogrodzkiego Mikołaja i krewni przodków Garwaskich - Miszewscy (później nazwani Mniszewskimi) h. Grzymała, używający przydomka Cztan. Por. ibidem, s. 284285 (tu jednak błędne połączenie $z$ Miszewem Cztanowym postaci Mikołaja Sowy, kasztelana wyszogrodzkiego). Por. też K. P a c u s k i, op. cit., s. 133-134, 430. 
majątkowych. W 1444 r. dokonał wymiany dóbr ze swoimi braćmi stryjecznymi (synami kasztelana wyszogrodzkiego Mikołaja Sowy), Andrzejem i Mikołajem $z$ Wkry (dawniej z Krawięczyna). W zamian za dziedziczny Garwarz w ziemi zawkrzeńskiej (sąsiadujący z Wkra w parafii Glinojeck) przejął (za dopłata) Krawięczyn (dziś Krawieczyn), wieś położoną w najbliższym sąsiedztwie Miszewa i Małoszewa (w parafii Bodzentyn, ale już na terenie sąsiadującej $z$ ziemia płocką ziemi wyszogrodzkiej). W 1453 r. Andrzej z Wkry, w zamian za kmiecia osiadłego w Miszewie, odstapił Janowi części Wkry i Garwarza, które przypadły mu po śmierci brata - Mikołaja z Garwarza (dawniej z Krawięczyna i z Wkry). W 1454 r. Jan z Miszewa wymienił 2 morgi ziemi uprawnej w Rybiu na 5 niezagospodarowanych włók w Reszkowie, czyli Reszkach pod Gąbinem. Na ziemi nabytej od Kunata, Jana, Stanisława i Marcina $z$ Reszkowa lokował następnie osadę o nazwie Staw. W 1458 r. Jan, dziedzic z Miszewa, kupił z kolei od Domarata $z$ Przeciszewa za 330 kóp groszy połowę wsi Przeciszewo (w ziemi płockiej, w parafii Zagroba), dając mu w rozliczeniu 1 włókę we Wkrze i zabezpieczając spłatę całej należności na swojej części Garwarza. Dążąc zaś do scalenia w swoim ręku całości dóbr rodowych na Zawkrzu (Wkra i Garwarz), nabył w 1463 r. kolejne części obu wiosek od Elżbiety, jedynej córki zmarłego przed dziesięciu laty Mikołaja $z$ Garwarza. W tym samym czasie odkupił również prawo bliższości do części Garwarza i Wkry od bratanków tegoż Mikołaja: Jana i Mikołaja $z$ Mchowa, synów Zdziesława (dawniej $z$ Krawięczyna). W efekcie wszystkich tych działań, w połowie lat sześćdziesiątych XV stulecia Jan z Miszewa był już dziedzicznym właścicielem sześciu wsi całych (Miszewo, Małoszewo, Krawięczyn, Garwarz, Rybie i Staw) oraz dwóch części wsi (Przeciszewo i Wkra), skupionych w czterech niewielkich kluczach majatkowych. Jeden $z$ nich tworzyły Miszewo, Małoszewo i Krawięczyn, drugi część Przeciszewa, trzeci Garwarz i część Wkry, a czwarty Rybie ze Stawem. W bliżej nieokreślonym czasie Jan $z$ Miszewa wszedł również w zastawne posiadanie książęcej wsi Chełpowo, leżącej w najbliższym sąsiedztwie Płocka i stanowiącej uposażenie zamku (starosty) płockiego. Wieś tę trzymał do końca swojego życia. Zastaw na Chełpowie przejęli następnie jego spadkobiercy ${ }^{6}$.

6 Por. KM, nr CCVII; Matricularum Regni Poloniae summaria, excussis codicibus, qui in Chartophylacio Maximo Varsoviensi asservantur [dalej: MRPS], t. IV, cz. 3, wyd. T. Wierzbowski, Warszawa 1915, nr 736; SHG-Płock, s. 37, 76, 185, 
Dysponując stosunkowo dużym majątkiem i dążąc do podniesienia rangi swojego rodu, Jan $z$ Miszewa zdecydował się ufundować parafię w swojej rodzinnej wiosce. Pierwsze starania o erygowanie parafii w Miszewie podjął już w 1445 r. Napotkał jednak na opór kapituły płockiej, która zażądała od niego zwiększenia uposażenia przyszłych plebanów. W $1448 \mathrm{r}$. Jan $\mathrm{z}$ Miszewa wystawił więc dokument, w którym nadawał proboszczowi 2 włóki pola, 2 siedliska na osadzenie ogrodników oraz siedlisko $z$ ogrodem dla plebana. Stwierdzał ponadto, że sam wybuduje dom dla proboszcza i przyzna mu dodatkowe uposażenie $z$ własnych dochodów. Przyszły zarządca parafii otrzymać miał również łąkę, prawo łowienia ryb w stawie oraz po jednym korcu pszenicy $z$ każdej włóki osiadłej w Miszewie i Małoszewie. Sprawa ciągnęłaby się zapewne przez kolejne lata, gdyby nie wsparcie, jakie uzyskał Jan ze strony ówczesnego biskupa płockiego - Pawła Giżyckiego h. Gozdawa. Zasadniczy problem polegał bowiem na tym, że nowa parafia miała powstać kosztem parafii w Bodzanowie, do której należały dotąd wsie Miszewo i Małoszewo (obie miały wejść w skład parafii miszewskiej). Już w 1450 r. biskup Paweł Giżycki uzyskał zgodę Ścibora $z$ Belska, archidiakona płockiego, oraz jego bratanka Ścibora, kanonika płockiego i proboszcza w Bodzanowie (odbywajacego wówczas podróż do Rzymu), na erygowanie parafii w Miszewie i wystawił dokument potwierdzajacy jej ustanowienie. Biskup płocki wsparł przy tej okazji starania Jana $z$ Miszewa również materialnie, gdyż rekompensując proboszczowi bodzanowskiemu utratę dochodów $z$ obu wiosek (dziesięciny $z$ włók chłopskich), które weszły w skład nowej parafii, zrezygnował na jego rzecz z przysługujących mu dotąd dziesięcin $z$ Małoszewa i Krawięczyna. W tym

193 (tu jednak błędna informacja, że Jan z Miszewa h. Grzymała zmarł w 1475 r.), 245, 330; SHG-Wyszogród, s. 29; J. Łe m p icki, Herbarz mazowiecki, t. I-II, Poznań 1997, s. 48 (z licznymi błędami); K. Pacuski, op. cit., s. 132-134; E. O palińs ki, op. cit., s. 86. Dodajmy w tym miejscu, że w 1455 r. Jan z Miszewa był właścicielem części wsi Pepłowo Nagórne w parafii Święcieniec. Wydaje się jednak, że w późniejszym okresie wyzbył się tej posiadłości. W 1468 r. Jan z Miszewa kupił jeszcze za 25 kóp groszy od Domarata z Dziedzic i Mikołaja z Przeciszewa ich części we wsi Susk w parafii Golemin. Transakcja ta została jednak anulowana w wyniku protestu złożonego ( $z$ tytułu prawa bliższości) przez Stanisława $z$ Witosławic oraz jego synów i bratanków. Por. SHG-Płock, s. 226, 245, 246. Nie do końca zgodne ze stanem faktycznym jest więc twierdzenie E. Opalińskiego, że Jan $z$ Miszewa był właścicielem 5 wsi. Por. i d e m, op. cit., s. 128. W rzeczywistości pozostawił on bowiem swoim spadkobiercom 6 wsi całych, 2 części wsi oraz zastaw na 1 wsi książęcej. 
samym roku, jak również dwa lata później (w 1452 r.), biskup Paweł Giżycki potwierdził podjęte przez siebie decyzje, oddalając roszczenia plebana bodzanowskiego do zwierzchnictwa nad kościołem w Miszewie ${ }^{7}$.

Jan $\mathrm{z}$ Miszewa pozostawał $\mathrm{w}$ bliskich stosunkach $\mathrm{z}$ dworem książąt płockich, początkowo Włodzisława I (zm. 1455) oraz jego młodocianych synów: Siemowita VI (zm. 1462) i Władysława II (zm. 1462), następnie zaś Konrada III Rudego (zm. 1503). Z rak pierwszego $z$ nich otrzymał nie tylko wspomniany przywilej z 1442 r., lecz także nominację na godność kasztelana raciąskiego, który to urząd obją w roku 1450 i sprawował przez następnych 18 lat. W 1468 r. ksiażę Konrad III Rudy, który po śmierci zmarłych $\mathrm{w}$ młodym wieku synów Włodzisława I objął rządy w dzielnicy płockiej, zdecydował się przesunąc Jana $z$ Miszewa $z$ kasztelanii raciąskiej na kasztelanię wiska, wakująca po śmierci Wincentego Giżyckiego h. Gozdawa (brata biskupa płockiego Pawła), jednego $z$ najpotężniejszych w owym czasie panów mazowieckich. Na nowej kasztelanii Jan Miszewski zasiadał jednak niezbyt długo, gdyż zmarł krótko po 16 grudnia 1471 r. ${ }^{8}$

Kasztelan wiski Jan $z$ Miszewa h. Grzymała pozostawił po sobie pięcioro dzieci: dwie córki oraz trzech synów. Jego starszą córka była Anna (być może najstarsza $z$ całego rodzeństwa), żona Jana Garbarza $z$ Kamienicy, która w 1471 r. skwitowała braci z zadośćuczynienia za dobra dziedziczne. Najmłodszym dzieckiem kasztelana była natomiast córka Katarzyna (zm. 1523), która pojawia się w źródłach stosunkowo późno, już jako wdowa po Stanisławie Targoni z Pniewnika (w ziemi liwskiej) i Kobyłki (w ziemi warszawskiej) h. Ślepowron (zm. 1490). W 1518 r. dokonała ona zapisu sumy na dobrach Pniewnik, Zakrzewo i Radomino w ziemi liwskiej, gdzie miała swoja oprawę wdowią, $z$ przeznaczeniem na ufundowanie ołtarza w kościele parafialnym w Liwie. Uczestniczyła té̇ w procesach o dziesięciny $z$ Miszewa i Małoszewa, które pod koniec

7 Por. SHG-Płock, s. 185, 194; SHG-Wyszogród, s. 6; E. O p a li ń s k i, op. cit., s. 128; SGKP, t. VI, Warszawa 1885, s. 506. Por. też T. Sł o wi k o w s k i, Giżycki Pawet, [w:] PSB, t. VIII, Wrocław-Warszawa-Kraków 1959-1960, s. 23-25.

8 Por. SHG-Płock, s. 193-194, 226; E. O p alińn ski, op. cit., s. 128; K. P a cuski, op. cit., s. 134. Por. też T. Słowikowski, Giżycki Pawet, [w:] PSB, t. VIII, s. 26-27; B. S o bo1, Konrad Rudy III, [w:] ibidem, t. XIII, WrocławWarszawa-Kraków 1967-1968, s. 595-597; K. Pacuski, A. Świeżawski, Siemowit VI, [w:] ibidem, t. XXXVII, Warszawa-Kraków 1996-1997, s. 85-85. 
drugiego dziesięciolecia XVI w. toczył jej bratanek - Jan z Miszewa Garwaski ${ }^{9}$.

Synami kasztelana wiskiego byli Filip, Mikołaj i Jan. Wszyscy oni zostali odnotowani $\mathrm{w}$ dokumencie $z$ roku 1471 , kiedy zostali skwitowani $z$ zadośćuczynienia za dobra po rodzicach przez siostre Annę. Najstarszy z braci - Filip - został wspomniany w 1473 r. jako syn nieżyjącego już Jana $z$ Miszewa, kasztelana wiskiego. W 1475 r. Filip, Mikołaj i Jan, synowie zmarłego kasztelana Jana, na własna prośbę uzyskali potwierdzenie transakcji kupna połowy Przeciszewa, nabytego przez ich ojca od Domarata $z$ Przeciszewa w 1458 r. W tym samym roku książę płocki Kazimierz III sprzedał Janowi z Radzanowa, stolnikowi płockiemu, wieś książęca Chełpowo, zezwalając mu jednocześnie na wykupienie jej $z$ rak spadkobierców nieżyjącego Jana $z$ Miszewa, kasztelana wiskiego. Nie zachował się niestety akt podziału dóbr po kasztelanie wiskim. Nie znamy również nawet przybliżonych dat śmierci jego synów. Wiemy natomiast, że nie piastowali oni żadnych urzędów. Jest także sprawa oczywista, że po podziale majątku ojcowskiego każdy $z$ nich dysponował zdecydowanie mniejszymi dobrami ziemskimi niż kasztelan wiski. Jeden $z$ kasztelaniców był też $z$ całą pewnościa bezpośrednim przodkiem Garwaskich. Opierając się na ustaleniach Kazimierza Pacuskiego, zawartych w jego niedrukowanej rozprawie doktorskiej, Edward Opaliński napisał, że najstarszy $z$ braci - Filip - zmarł bezpotomnie, a jego majątkiem podzielili się Mikołaj i Jan, który był ojcem występującego w pierwszej połowie XVI w. Jana Garwaskiego. W opublikowanej w 2009 r. ksiażce K. Pacuskiego, która jest udoskonaloną wersja jego doktoratu, nie odnajdujemy jednak najmniejszego nawet śladu tego stwierdzenia. Zamiast tego pojawia się informacja, że kasztelanic wiski Filip (zm. p. 1523) otrzymał $w$ dziale $z$ braćmi Małoszewo w ziemi płockiej oraz Rybie i Staw w ziemi gostynińskiej i pozostawił po sobie syna Jana $z$ Małoszewa Rybskiego (zm. p. 1547), protoplastę rodziny Rybskich h. Grzymała. Jego synem był też zapewne Stanisław Dubiel ze Stawu, przodek Stawowskich. Nieco światła na genealogię

9 Por. Słownik historyczno-geograficzny ziemi warszawskiej $w$ średniowieczu, oprac. A. Wolff, K. Pacuski, do druku podały M. Piber-Zbieranowska i A. Salina, red. T. Jurek, Warszawa 2013, s. 108; Słownik-Płock, s. 193-194. Dodajmy również, że młodsza córka kasztelana wiskiego - Katarzyna $z$ Miszewa - była zapewne druga żoną Stanisława Targoni. W żadnym dokumencie nie została bowiem wspomniana jako matka jego dzieci - syna Bernarda i córek: Heleny, żony Jana z Grodziska, oraz Anny, żony Jana z Klembowa. 
Grzymalitów z Miszewa rzuca też przywołana przez K. Pacuskiego informacja, że w marcu 1518 r. oba dokumenty nadań księcia Wacława płockiego dla kasztelana wyszogrodzkiego Mikołaja z $1319 \mathrm{r}$. zostały wpisane do metryki koronnej na prośbę Jana Miszewskiego z Garwarza (Jana Garwaskiego) oraz jego braci stryjecznych Jana Rybskiego z Małoszewa i Andrzeja Wkrzeńskiego. Wnioskując na podstawie faktu, że Jan Garwaski odziedziczył po Mikołaju wieś Miszewo, K. Pacuski uznał go za syna średniego kasztelanica wiskiego, a ojcostwo Andrzeja Wkrzeńskiego przypisał najmłodszemu z synów zmarłego w 1471 r. kasztelana - Janowi10.

W moim przekonaniu cały ten wywód oparty został jednak na zbyt wątłych, a częśsiowo również błędnych przesłankach. Skądinąd wiemy bowiem, że średni syn Jana $z$ Miszewa - Mikołaj, nazywany w źródłach Miszewskim lub też Wiskim z Krawięczyna był właścicielem Miszewa, Krawięczyna i zapewne części Małoszewa. Tenże Mikołaj, stwierdzając, że nie jest w stanie uiszczać dziesięciny ze swoich dóbr, wystapił w 1500 r. z żądaniem zwrotu 2 włók darowanych niegdyś przez jego ojca parafii w Miszewie (nazywanym wtedy Miszewem Wiskim). Przy okazji toczącego się wówczas procesu ustalono, że proboszcz miszewski ma prawo do połowy dziesięcin $z$ włók chłopskich w Miszewie, jak również do dziesięcin $z$ folwarku oraz z 2 włók stanowiących uposażenie parafii. Druga połowa dziesięcin $z$ włók chłopskich w Miszewie przypadać miała natomiast klasztorowi norbertanek pw. św. Marii Magdaleny w Płocku. Mikołaj Wiski z Krawięczyna odnotowany został jeszcze w dokumencie $z 1501$ r. Zmarł najprawdopodobniej wkrótce potem. Niemal nic nie można natomiast powiedzieć o najmłodszym kasztelanicu wiskim - Janie. Wnioskując na podstawie danych pośrednich, możemy przypuszczać, że po śmierci ojca przypadł mu dział majątkowy obejmujący Garwarz, część Wkry i połowę Przeciszewa. Nie znamy niestety daty jego śmierci. Nie możemy też jednoznacznie stwierdzić, czy dożył chwili, kiedy Mazowsze Płockie zostało włączone do Korony, co nastapiło w roku 1495. Nie wydaje się natomiast, by przeżył on brata Mikołaja. Na podstawie zachowanych wzmianek źródłowych nie możemy też z pełnym przekonaniem odpowiedzieć na pytanie, który $z$ młodszych synów kasztelana wiskiego był ojcem Jana Garwaskiego. W posiadaniu tego ostat-

10 Por. SHG-Płock, s. 37, 193-194; SHG-Wyszogród, s. 29; E. O p a 1 iń s ki, op. cit., s. 128; K. Pacuski, op. cit., s. 134-135; MRPS, t. IV, cz. 2, wyd. T. Wierzbowski, Warszawa 1912, nr 11489. 
niego znalazły się bowiem dobra należące wcześniej zarówno do Mikołaja Miszewskiego $z$ Krawięczyna, jak i do Jana $z$ Garwarza, Wkry i Przeciszewa. W każdym bądź razie jeden $z$ nich $z$ cała pewnościa był ojcem Jana Miszewskiego $z$ Garwarza sive Jana Garwaskiego $z$ Miszewa, drugi natomiast zmarł bezpotomnie. Wspomniany w roku 1518 Andrzej Wkrzeński nie był natomiast wnukiem kasztelana wiskiego Jana $z$ Miszewa (zm. 1471), tylko potomkiem (najpewniej praprawnukiem) jego stryja, kasztelana wyszogrodzkiego Mikołaja Sowy (zm. 1442) ${ }^{11}$.

Nie znamy niestety żadnej $z$ żon przedstawicieli pierwszych pokoleń rodu Garwaskich, więc podczaszego płockiego Filipa, kasztelana wiskiego Jana ani też jego synów: Filipa, Mikołaja i Jana. Wiemy natomiast, że siostra kasztelana wiskiego poślubiła Andrzeja $z$ Koziebród, podczaszego dworu ksiażąt płockich, a jego córki wyszły za maż za Jana Garbarza $z$ Kamienicy oraz za Stanisława Targonię z Pniewnika i Kobyłki. Edward Opaliński, wnioskując jedynie na podstawie pierwszego $z$ wymienionych tu mariaży, wyraził przypuszczenie, że małżeństwa tej rodziny zamykały się $\mathrm{w}$ kręgu familii związanych $\mathrm{z}$ dworem książąt mazowieckich ${ }^{12}$. Jest

11 Dodajmy w tym miejscu, że K. Pacuski, opierajac się na ustaleniach J. Łempickiego, stwierdza, że Rybscy h. Grzymała byli właścicielami Małoszewa przynajmniej do roku 1559. Por. K. P a c u s ki, op. cit., s. 134; J. Łe m p i cki, op. cit., t. I-II, s. 49 (tu stwierdzenie, że Rybscy byli właścicielami Małoszewa w latach 1538-1590). W rzeczywistości w rękach tej rodziny pozostawać mogła co najwyżej część tej wioski. Swój dział w Małoszewie miał bowiem $z$ pewnością również Jan Garwaski. Jeśli założymy, że dziedziczył on część Małoszewa po Mikołaju (co wydaje się najbardziej prawdopodobne) i potraktujemy dosłownie zawarte w przywołanym niżej dokumencie (por. przypis 13) sformułowanie o jego „ojcowiźnie” w tej osadzie, to możemy chyba uznać, że Jan Garwaski z Miszewa rzeczywiście był synem Mikołaja Miszewskiego $z$ Krawięczyna. Nie jest to jednak w żadnym razie stwierdzenie kategoryczne i niepodważalne. Por. SHG-Płock, s. 37, 193-194; SHG-Wyszogród, s. 29. Jeśli chodzi natomiast o pochodzenie Andrzeja Wkrzeńskiego, to na pewno możemy wykluczyć jego bliskie pokrewieństwo z Garwaskimi. W moim przekonaniu był on praprawnukiem kasztelana wyszogrodzkiego Mikołaja Sowy (zm. 1442), prawnukiem Andrzeja (zm. po 1468), który przeprowadzał wspomniane transakcje majątkowe $z$ kasztelanem wiskim Janem $z$ Miszewa $(\mathrm{zm}$. 1471), wnukiem zaś Andrzeja, któremu w 1497 r. król Jan Olbracht skonfiskował dobra za niestawiennictwo na wyprawie wojennej. Ojcem Andrzeja Wkrzeńskiego był zapewne wspomniany przy tej samej okazji żonaty syn Andrzeja - Mikołaj, którego dobra również uległy wówczas konfiskacie. Co warte podkreślenia, pradziad, dziad i ojciec Andrzeja Wkrzeńskiego byli posiadaczami części Wkry i stamtąd właśnie się pisali. Por. SHG-Płock, s. 330.

12 Por. E. O palińs ki, op. cit., s. 42. Dodajmy także, że młodszy brat Andrzeja $z$ Koziebród - Jan - osiagnął z czasem godność kasztelana sierpskiego, 
to stwierdzenie na tyle ogólne, że $z$ pewnościa możliwe do zaakceptowania. Sadząc po małżeństwach siostry i córek Jana $z$ Miszewa, trudno byłoby bowiem wyobrazić sobie, że piętnastowieczni panowie na Miszewie i Garwarzu mogliby wchodzić w koligacje, które nie prowadziłyby do utrwalenia ich statusu materialnego i osiagniętej pozycji.

Po śmierci ostatniego $z$ synów kasztelana wiskiego jedynym męskim przedstawicielem rodu dziedziczacym na Miszewie i Garwarzu był jego wnuk - Jan $z$ Miszewa Garwaski (zm. 1540). Jest on jednocześnie pierwszym reprezentantem rodziny odnotowanym przez herbarze. Po śmierci ojca i stryja Jan Garwaski z Miszewa, który używał również nazwiska Miszewski $z$ Garwarza, skupił w swoim ręku (dzięki wykupieniu pretensji do połowy spadku po bezpotomnym stryju od braci stryjecznych dziedziczacych na Rybiu i Stawie) wszystkie wsie rodowe położone w województwie płockim oraz w ziemi wyszogrodzkiej. W 1520 r., kontynuując spór rozpoczęty przez Mikołaja Miszewskiego z Krawięczyna, procesował się z klasztorem św. Marii Magdaleny w Płocku oraz z plebanem $\mathrm{w}$ Miszewie o nieuiszczanie dziesięciny snopowej $z 7$ włók osiadłych. Po niekorzystnym dla siebie wyroku musiał zapłacić klasztorowi 15 kóp groszy w półgroszkach, a plebanowi miszewskiemu oddać część ojcowizny we wsi Małoszewo (folwark o nazwie Okrąglica). W tym samym czasie Jan Garwaski ufundował ołtarz w kościele parafialnym w Miszewie, przeznaczając na utrzymanie altarysty 1 włókę roli w Małoszewie oraz dziesięcinę z 4 włók osiadłych w siedzibie parafii. Jan Garwaski był również pierwszym przedstawicielem rodu, który sprawował mazowieckie urzędy ziemskie w XVI stuleciu. Przed 1529 r. otrzymał bowiem nominacje na urząd stolnika wyszogrodzkiego, a w roku 1531 został cześnikiem płockim. Był właścicielem lub współwłaścicielem wszystkich wiosek na prawym brzegu Wisły, które należały wcześniej do jego dziadka Miszewa (7 włók osiadłych), Małoszewa (5 włók osiadłych - część tej wsi była własnością Rybskich h. Grzymała), Krawięczyna (6 włók osiadłych), Garwarza (5 włók osiadłych), części Wkry (bez podania liczby łanów) i połowy Przeciszewa (5 włók osiadłych). Przed $1531 \mathrm{r}$. kupił też wieś Brochocin (5 włók osiadłych) w powiecie płockim, $\mathrm{w}$ parafii Trzepowo. Możemy też przypuszczać, że w ostatnich latach życia nabył także Wolę Młocką (8 włók osiadłych) w ziemi

a następnie raciąskiego. Por. SHG-Płock, s. 144. Zięciowie kasztelana wiskiego Jana $z$ Miszewa nie sprawowali natomiast żadnych urzędów. 
zawkrzeńskiej, w parafii Malużyn. Majątek Jana z Miszewa Garwaskiego składał się więc z 5 wsi całych oraz 3 części wsi, w których w 1531 r. odnotowano około 41 włók osiadłych. Jak na stosunki mazowieckie, była to całkiem spora fortuna ${ }^{13}$.

Jan Garwaski zawarł małżeństwo, którego znaczenia dla przyszłości rodu nie sposób przecenić. Poślubił mianowicie Zofię Dzierzgowska h. Jastrzębiec, córkę Pomścibora, kasztelana ciechanowskiego, i Katarzyny Wilkanowskiej h. Lis. Żona Garwaskiego pochodziła $z$ rodziny, która od kilku pokoleń piastowała mazowieckie urzędy ziemskie. Jej dziad Mikołaj był kasztelanem warszawskim, a pradziad Nadbor - cześnikiem ciechanowskim. W chwili zawierania tego związku, więc około 1510 r., nic nie wskazywało jednak na to, że będzie to mariaż tak korzystny dla Garwaskich. Teść Jana - Pomścibór Dzierzgowski - był co prawda kasztelanem ciechanowskim i dzierżawca bogatego starostwa łomżyńskiego, ale nie dysponował zbyt dużymi dobrami alodialnymi. Nie względy materialne decydowały jednak tak naprawdę o wartości tej koligacji. Zofia Garwaska była bowiem rodzona siostra Anny oraz Jana i Mikołaja Dzierzgowskich. Anna Dzierzgowska poślubiła Pawła Kiernoskiego h. Junosza (zm. 1546), kasztelana gostynińskiego, a po jego śmierci wyszła ponownie za mąż za Marcina Śleszyńskiego h. Wieniawa (zm. 1578), wojskiego gostynińskiego. O ile jednak mężowie Anny pochodzili $z$ urzędniczych rodzin średnioszlacheckich, to już obaj jej bracia zrobili zawrotna wręcz karierę. Jan (zm. 1554) był początkowo skromnym stolnikiem ciechanowskim. W $1532 \mathrm{r}$. otrzymał jednak nominację na kasztelanię ciechanowską, w roku 1542 został kasztelanem czerskim, by w 1544 r. awansować na urząd wojewody i wicesgerensa (namiestnika) księstwa mazowieckiego. Urzędy senatorskie łączył $z$ dzierżawą starostw - warszawskiego (od 1533 r.), nurskiego (od 1550 r.) i łomżyńskiego (od 1551 r.). Ożeniony z Dorotą Sobocką h. Doliwa (zm. 1548), siostra

13 Por. B o n i e cki, Herbarz, t. IV, s. 378 (tu błędna informacja, że Garwarz, z którego pisali się Garwascy, leżał w ziemi ciechanowskiej); U ru s ki, Herbarz, t. V, s. 103; N i e s i e c ki, Herbarz, t. IV, s. 76; MRPS, t. IV, cz. 2, nr 12955; SHGPłock, s. 25, 75-76, 185, 194, 245, 330, 332; SHG-Wyszogród, s. 29; SGKP, t. XIII, Warszawa 1898, s. 792; J. Łe m picki, op. cit., t. I-II, s. 14, 285 (tu informacja, że Jan Garwaski kupił Wolę Młocką od Stanisława i Zygmunta Młockich w roku 1542. Zważywszy jednak na liczne błędy w tym opracowaniu, datowanie tej transakcji na rok 1542 jest mało wiarygodne. Autor ten stwierdza bowiem dalej, że Jan Garwaski, cześnik płocki jeszcze w 1559 r., udzielił pożyczki Janowi Rybskiemu i zmarł bezdzietnie!). 
kanclerza wielkiego koronnego Tomasza (zm. 1547), pozostawił po sobie córkę Dorotę i syna Feliksa Zbożnego (Auctusa). Awanse Jana Dzierzgowskiego pozostawały w bezpośrednim zwiąku $z$ kariera kościelna jego brata Mikołaja (zm. 1559). Ten ostatni, protegowany Andrzeja Krzyckiego, Piotra Gamrata i królowej Bony, dość długo czekał na sakrę biskupią. Dopiero w marcu 1541 r., mając około 50 lat, został bowiem biskupem kamienieckim. Zanim jednak otrzymał potwierdzenie papieskie, w drugiej połowie tego samego roku otrzymał nominację na biskupstwo chełmskie. W styczniu 1543 r. Zygmunt I Stary przeniósł z kolei Mikołaja Dzierzgowskiego na bogate biskupstwo kujawskie. Awans ten pozostaje w niewątpliwym związku $z$ wyniesieniem Jana Dzierzgowskiego do godności wojewody mazowieckiego w roku następnym. W 1545 r., po śmierci swojego protektora i przyjaciela Piotra Gamrata, Mikołaj Dzierzgowski obją wreszcie wakująca po nim godność arcybiskupa gnieźnieńskiego ${ }^{14}$.

Jest sprawą oczywista, że $z$ wyniesienia braci Dzierzgowskich korzystali również ich krewni i powinowaci. Awanse szwagrów nie wywarły jednak żadnego wpływu na karierę Jana Garwaskiego, gdyż zmarł on najprawdopodobniej już pod koniec 1539 lub też w pierwszych miesiącach 1540 r., więc w czasie, kiedy Mikołaj Dzierzgowski był jedynie dziekanem płockim, a jego brat kasztelanem ciechanowskim. Zwiazki rodzinne $z$ Dzierzgowskimi okazały się jednak bardzo korzystne dla dzieci cześnika płockiego. $Z$ małżeństwa $z$ Zofią Dzierzgowska pozostawił córki Zofię i Annę oraz synów Pawła, Piotra i Hieronima. Starsza córka Jana Garwaskiego - Zofia - poślubiła Pawła Młockiego h. Prawdzic. Nic więcej o niej nie wiadomo. Młodsza - Anna - umarła prawdopodobnie jako panna. Młodo i bezpotomnie, najpewniej wkrótce po śmierci ojca, zmarł także średni syn cześnika - Piotr - wspomniany w płockich aktach

14 Por. B o n i e cki, Herbarz, t. V, s. 191-192; Ni e s i e c ki, Herbarz, t. IV, s. 76 ; t. V, Lipsk 1840, s. 82 ; t. VIII, Lipsk 1841, s. 400; B. P a p r o c k i, Herby rycerstwa polskiego, wyd. K.J. Turowski, Kraków 1858, s. 172; K. P a c u s ki, op. cit., s. 142; J. P i ę t k a, Mazowiecka elita feudalna późnego średniowiecza, Warszawa 1975, s. 60-63 (tu informacje o przodkach braci Dzierzgowskich); W. P o ci e ch a, Dzierzgowski Mikołaj, [w:] PSB, t. VI, Kraków 1948, s. 145-150; P. Gaw ron, A. Moniuszko, op. cit., s. 135; H. Kow a $1 \mathrm{~s} \mathrm{k} \mathrm{a,} \mathrm{Sobocki} \mathrm{Tomasz,}$ [w:] PSB, t. XXXIX, Warszawa-Kraków 1999-2000, s. 557-560. Warto w tym miejscu dodać, że przychylność potężnego Piotra Gamrata dla braci Dzierzgowskich wynikała też $z$ tego, że jego długoletnią przyjaciółką (współcześni podejrzewali, że również kochanka) była żona Jana, Dorota $z$ Sobockich, zaufana powiernica królowej Bony. Por. K. H a r t1 e b, Gamrat Piotr, [w:] PSB, t. VII, s. 266. 
grodzkich w 1539 r. W tej sytuacji dziedzicami fortuny i nazwiska Garwaskich zostali dwaj synowie Jana: Paweł i Hieronim. Zarówno jeden, jak i drugi w pełni potrafili wykorzystać bliskie pokrewieństwo łaczace ich $z$ prymasem oraz $z$ wojewoda mazowieckim ${ }^{15}$.

Najmłodszy $z$ synów cześnika płockiego Jana Garwaskiego i Zofii Dzierzgowskiej - Hieronim (zm. 1583) - wybrał karierę kościelną. Jeszcze jako student teologii został w 1547 r. kanonikiem gnieźnieńskim za prowizją swego wuja, arcybiskupa Mikołaja Dzierzgowskiego. W 1551 r., zabiegajacc o wejście do kapituły krakowskiej, wdał się w gorszacy spór o kanonię $z$ Janem Korzbokiem Witkowskim, który otrzymał nominacje $z$ rak nowego biskupa krakowskiego - Andrzeja Zebrzydowskiego. Po dłuższych przepychankach, mimo osobistej interwencji Mikołaja Dzierzgowskiego, ostatecznie na kanonii utrzymał się jednak przeciwnik Garwaskiego. Co prawda, pod naciskiem prymasa, 10 lutego 1553 r. kapituła krakowska ekskludowała Witkowskiego ze swego składu, ale po kilku tygodniach przywrócono go na sporną kanonię. Czyniąc ukłon w stronę arcybiskupa i jego siostrzeńca, członkowie kapituły podjęli równocześnie decyzję, że Hieronim Garwaski będzie mógł objąć sporne beneficjum po ewentualnym ustapieniu $z$ niego Jana Korzboka Witkowskiego. Dzięki protekcji prymasa Garwaski został w 1553 r. kanonikiem łowickim. Nie zadowoliło to jednak jego protektora. Sązić bowiem wypada, że prymas Dzierzgowski za punkt honoru uznał umieszczenie siostrzeńca w składzie kapituły krakowskiej. Dnia 8 lipca 1554 r. Hieronim Garwaski został więc instalowany na kanonię krakowska fundi Chmielniki. Co jednak ciekawe, już w roku następnym, zapewne zgodnie $z$ życzeniem wuja, zrezygnował $z$ tej kanonii na rzecz Franciszka Krasińskiego. Decyzję tę wiązać chyba należy $z$ powierzeniem Garwaskiemu urzędu kanclerza kapituły gnieźnieńskiej, co nastapiło w roku 1554. Objęcie tej prałatury wymagało bowiem bez watpienia jego częstszej obecności w Gnieźnie. Sądzić wypada, że nowy kanclerz gnieźnieński spędzał też sporo czasu na dworze arcybiskupim. Był

15 Por. B o n i e cki, Herbarz, t. V, s. 378; Słownik-Płock, s. 194; U r u s ki, Herbarz, t. IV, s. 103 (tu informacja, że Jan Garwaski pozostawił z Zofii Dzierzgowskiej jedynie dwóch synów: Pawła i Hieronima); P. Gawron, A. Moniuszko, op. cit., s. 135 (tu także informacja, że Jan Garwaski z małżeństwa z Zofią Dzierzgowska miał tylko dwóch synów); J. Łe mpicki, op. cit., t. I-II, s. 49 (tu informacja, że w 1548 r. dziedzicem Miszewa Garwaskiego był Piotr Garwaski. Ponieważ jednak tytułowany jest on cześnikiem płockim, nie ulega wątpliwości, że chodzi o jego brata Pawła). 
bowiem zaufanym prałatem domowym wuja prymasa, który uczynił go też wykonawca swojego testamentu. Po śmierci Mikołaja Dzierzgowskiego, który zmarł w Łowiczu 18 stycznia 1559 r., Hieronim Garwaski nie utracił dotychczasowego znaczenia. $Z$ duża zręcznościa pozyskiwał nowe beneficja. Do posiadanych prałatur dodał kanonie łęczycka, uniejowska i płocka (w 1563 r.) oraz dziekanię łowicką. Został też sekretarzem Zygmunta Augusta. Jako sekretarz królewski i kanclerz gnieźnieński na sejmie lubelskim z 1569 r. został powołany do grona lustratorów dóbr królewskich w Wielkopolsce. Po śmierci Jana Korzboka Witkowskiego, przez dokonana w dniu 17 sierpnia 1572 r. instalację na kanonię fundi Dojazdów, wszedł ponownie w skład kapituły krakowskiej. Od tej pory najczęściej przebywał w Krakowie, biorac czynny udział w pracach miejscowej kapituły. Utrzymywał też rozliczne kontakty $z$ kapituła gnieźnieńska. Przez całe życie zabiegał o pomnożenie swojego majątku. Skumulował w swym ręku osiem dochodowych prałatur: kanclerstwo gnieźnieńskie, dziekanię łowicką oraz kanonie: gnieźnieńska, łowicką, łęczycką, płocką, uniejowska i krakowską. Pożyczał też pieniądze różnego rodzaju kontrahentom, m.in. Andrzejowi Gosławskiemu (szwagrowi swojego brata Pawła). W 1572 r. uzyskał intromisję do należącego do Gosławskiego miasta Licheń w powiecie konińskim za niespłacony dług w wysokości 1000 złotych. Przed 1579 r. wykupił też od klasztoru norbertanek w Płocku wójtostwo w miasteczku Bodzanów, które zostało następnie włączone do dóbr miszewskich. Po śmierci starszego brata Pawła opiekował się jego nieletnimi synami. Wspierał ich materialnie i zadbał o ich staranne wykształcenie. Przyczynił się też zapewne w decydującym stopniu do zaaranżowania małżeństw swoich dwóch bratanków - Pawła i Jerzego. Hieronim Garwaski zmarł w połowie lutego 1583 r., najpewniej w Krakowie ${ }^{16}$.

16 Por. Biblioteka Kórnicka Polskiej Akademii Nauk [dalej: BKPAN], Teki Dworzaczka [dalej: TD], Grodzkie i ziemskie, Konin, 3966 (Nr. 16 I. i Rel. Kon. 16), 1572, f. 229v; MRPS, t. V, cz. 2, oprac. J. Płocha, A. Rybarski, I. Sułkowska, red. J. Sawicki, Warszawa 1961, nr 6167, 6207; Volumina legum [dalej: Vol. leg.], wyd. J. Ohryzko, t. II, Petersburg 1859, s. 97; Posłowie ziemscy koronni 1493-1600 [dalej: Posłowie koronni], red. I. Kaniewska, Warszawa 2013, s. 90, 114; B. P a p r o c k i, op. cit., s. 615; i d e m, Gniazdo cnoty, Kraków 1578, s. 1049; B o n i e ck i, Herbarz, t. V, s. 378; U r u s k i, Herbarz, t. IV, s. 103; N i e s i e c ki, Herbarz, t. IV, s. 76; L. Łę to w s ki, Katalog biskupów, prałatów i kanoników diecezji krakowskiej, t. II, Kraków 1852, s. 240; J. K o r y t k o w s k i, Prałaci $i$ kanonicy katedry metropolitarnej gnieźnieńskiej, t. IV, Gniezno 1883, s. 312 i n.; i d e m, Arcybiskupi gnieźnieńscy, prymasowie i metropolici polscy od roku 1000 aż do 1821 , 
Najstarszy syn Jana, cześnika płockiego, i Zofii Dzierzgowskiej - Paweł Garwaski (zm. 1560) - nie był postacia tak znaczaca, jak jego młodszy brat Hieronim. Być może wynikało to $z$ tego, że zmarł stosunkowo wcześnie, niemal ćwierć wieku przed kanclerzem gnieźnieńskim. Jak można przypuszczać, urodził się na początku drugiego dziesięciolecia XVI w. W listopadzie 1538 r. uzyskał mandat poselski na sejmiku szlachty płockiej w Raciążu i posłował na sejm obradujący w Krakowie na przełomie 1538 i 1539 r. W roku następnym, po śmierci ojca, uzyskał nominację na opróżniony przez niego urząd cześnika płockiego. Dopiero po 13 kolejnych latach doczekał się awansu senatorskiego. Wybrany ponownie posłem na sejmiku w Raciążu, wzią udział w obradach sejmu 1553 r. W trakcie jego trwania, 9 marca 1553 r., został mianowany przez Zygmunta Augusta kasztelanem sierpskim. Można przypuszczać, że istotny wpływ na tę nominację wywarła protekcja ze strony arcybiskupa gnieźnieńskiego Mikołaja Dzierzgowskiego. Prymas wsparł również swojego siostrzeńca materialnie, powierzając mu (przed 1552 r.) zarząd klucza uniejowskiego dóbr arcybiskupich. Jak można przypuszczać, „starosta” uniejowskim pozostał Garwaski aż do śmierci swego protektora, czyli do roku 1559. Nie wiemy, czy Paweł i Hieronim Garwascy dokonali formalnego podziału dóbr po ojcu (wiadomo tylko, że każdy $z$ nich posiadał własną część wsi Wola Młocka w ziemi zawkrzeńskiej). W każdym razie kasztelan sierpski nie powiększył majątku rodowego. Jego synowie, dziedzicząc po ojcu i stryju, dysponowali bowiem tymi samymi dobrami, które pozostawały już w rękach ich dziadka - cześnika płockiego Jana Garwaskiego (zm. 1540). Paweł Garwaski zmarł w pierwszych miesiącach (przed 12 kwietnia) 1560 r. ${ }^{17}$ Pozostawił po sobie sześcioro dzieci.

t. III, Poznań 1889, s. 143, 216, 224; J. W i e te s k a, Katalog prałatów $i$ kanoników prymasowskiej kapituły łowickiej od 1433 do 1970, Warszawa 1971, s. 42; T. G i e m m a, op. cit., s. 290-291; W. U r b a n, Korzbok Witkowski Jan, [w:] PSB, t. XIV, Wrocław-Warszawa-Kraków 1968-1969, s. 160-161; E. O p a 1 iń ski, op. cit., s. 57, 112 (tu stwierdzenie, że Hieronim Garwaski skupił w swoim ręku 7 kanonii. Pomyłka ta wynika $z$ tego, że $w$ dokonanych tu obliczeniach nie uwzględniono kanonii łęczyckiej); J. Łe m picki, op. cit., t. I-II, s. 72 (tu informacja, że wójtostwo w Bodzanowie kupił od norbertanek płockich Hieronim Garwaski, po którym w 1579 r. odziedziczył je jego bratanek Piotr!); K. P e łk a, op. cit. (z błędami).

17 Por. B on i e cki, Herbarz, t. V, s. 378; U r u s k i, Herbarz, t. IV, s. 103 (tu błędna informacja, że Paweł Garwaski był dziedzicem Kutna); MRPS, t. V, cz. 2, nr 1639; T. Ż e b r o w s k i, Kasztelania sierpecka i jej kasztelani, [w:] Dzieje Sierp- 
Kasztelan sierpski Paweł Garwaski zawarł bardzo prestiżowe i korzystne małżeństwo. Jego żona została bowiem Elżbieta $z$ Kutna Kucieńska h. Ogończyk, córka Stanisława (zm. 1542), wojewody rawskiego, i Jadwigi $z$ Łaska h. Korab ${ }^{18}$. W chwili ślubu, do którego doszło najpewniej w 1548 lub 1549 r., Garwaski był jeszcze tylko skromnym cześnikiem płockim. Wydaje się więc, że również w kwestii zaaranżowania swojego mariażu skorzystał ze wsparcia i protekcji ogromnie wpływowego wuja, prymasa Mikołaja Dzierzgowskiego. Żona wniosła późniejszemu kasztelanowi sierpskiemu posag w wysokości 1000 florenów, który Kucieńscy wypłacili w dwóch ratach. W 1552 r. Paweł Garwaski, cześnik płocki i „starosta" uniejowski, skwitował bowiem wojewodzinę rawską Jadwigę $z$ Łaska Kucieńską i jej synów Jerzego, Mikołaja i Jana z przekazania mu kwoty 500 florenów, czyli drugiej i ostatniej zarazem raty należnego mu posagu. W roku następnym Garwaski został kasztelanem sierpskim. Zmarł, jak wspomniano, po około 10 latach małżeństwa, w początkach 1560 r. Elżbieta z Kutna Garwaska przeżyła swojego małżonka. Odnotowano bowiem jej wystąpienie w aktach urzędowych w dniu 23 stycznia 1561 r. ${ }^{19}$

ca i ziemi sierpeckiej, red. M. Chudzyński, Sierpc 2003, s. 109; E. O p a li ń s ki, op. cit., s. 57, 115; T. N o w a k, Kutno i Łakoszyn do schyłku XVI wieku, [w:] Kutno poprzez wieki, red. J. Szymczak, t. I (Do 1939 roku), Kutno-Łódź 2011, s. 145; Słownik-Płock, s. 76; SGKP, t. XIII, s. 792.

18 Warto zwrócić w tym miejscu uwagę na to, że w literaturze heraldyczno-genealogicznej brakuje jakiejkolwiek wzmianki o żonie kasztelana sierpskiego. Por. N i e s i e c ki, Herbarz, t. IV, s. 76-77 (tu pominięto nawet osobę Pawła Garwaskiego); t. V, Lipsk 1840, s. 430; B on i e cki, Herbarz, t. V, s. 378; t. XIII, Warszawa 1909, s. 91 (tu wspomniano jedynie o żonie i synach wojewody rawskiego Stanisława Kucieńskiego); Uruski, Herbarz, t. IV, s. 103. Dopiero K. Lepszy w biogramie Stanisława Garwaskiego opublikowanym w PSB stwierdził, że rodzicami jego bohatera byli Pawel, kasztelan sierpski, i nieznana $z$ imienia Kucieńska. Por. id e m, op. cit., s. 291. Informację tę powtórzyli następnie E. Opaliński, por. id e m, op. cit., s. 79 oraz P. Gawron i A. Moniuszko, por. e o r u n d e m, op. cit., s. 136. Szczegółowa genealogię dziedziczącej na Kutnie młodszej linii rodu Kucieńskich ( $\mathrm{z}$ nowymi ustaleniami dotyczącymi małżeństwa Pawła Garwaskiego z Elżbietą Kucieńską) opracował natomiast T. Nowak. Por. i d e m, op. cit., s. 143-147. Dodajmy także, że w genealogii znanego rodu Łaskich h. Korab w ogóle nie odnotowano Jadwigi z Łaska, żony Stanisława Kucieńskiego i matki wszystkich jego dzieci. Być może pochodziła więc ona ze znanej i zamożnej rodziny Russockich, którzy konsekwentnie pisali się $z$ Łaska i tak samo jak Łascy używali herbu Korab.

19 Por. MRPS, t. V, cz. 2, nr 6207, 8869, 8938; T. N ow a k, op. cit., s. 145. 
Wkrótce po śmierci Pawła Garwaskiego miało się okazać, że jego żona i dzieci wejda w najbliższym czasie w posiadanie bardzo znacznego majątku. Aby sprawę wyjaśnić, musimy słów kilka poświęcić omówieniu sytuacji w najbliższej rodzinie Elżbiety z Kutna Garwaskiej. Pochodziła ona $z$ rodu o długich tradycjach wielkosenatorskich. Już jej pradziad - Andrzej Kucieński (zm. 1503) - pełnił urząd wojewody rawskiego. Na tym samym krześle senatorskim zasiadał również jej dziadek, także Andrzej (zm. 1530), młodszy syn poprzedniego, protoplasta linii Kucieńskich dziedziczącej na Kutnie. Ożeniony z Elżbietą Kretkowską h. Dołęga, córką Andrzeja (zm. 1480), wojewody brzeskiego-kujawskiego (właśnie po tej babce otrzymała swoje imię późniejsza kasztelanowa sierpska), pozostawił jedynego syna - Stanisława. Ten ostatni, ojciec Elżbiety Garwaskiej, podobnie jak jego przodkowie, urząd wojewody rawskiego objął po rezygnacji ojca w kwietniu 1530 r. Zmarł przed 20 grudnia 1542 r. $Z$ małżeństwa $z$ Jadwiga $z$ Łaska pozostawił, oprócz wspomnianej najstarszej córki Elżbiety, czterech synów i dwie młodsze córki. Synami Stanisława Kucieńskiego byli Jerzy, Mikołaj, Jan i Stanisław, a córkami Jadwiga i Urszula. Synowie wojewody rawskiego umierali $\mathrm{w}$ młodym wieku. Najmłodszy $z$ nich Stanisław - zmarł zapewne już w 1545 r. Zgon Mikołaja nastapił krótko po 1552, a Jana po 1558 r. Najdłużej żył najstarszy z braci - Jerzy. Początkowo sekretarz i dworzanin królewski, 12 kwietnia 1560 r. otrzymał on nominację na urząd kasztelana sierpskiego wakujacy po śmierci Pawła Garwaskiego. Kasztelania sierpska cieszył się jednak zaledwie przez kilka miesięcy, gdyż zmarł przed 18 lipca tego samego roku. Jerzy był ostatnim męskim przedstawicielem młodszej linii Kucieńskich. Jadwiga $z$ Łaska przeżyła wszystkich swoich synów. Żyła bowiem jeszcze w 1561 r. Po śmierci synów i żony wojewody rawskiego Stanisława Kucieńskiego Kutno z przyległymi dobrami przeszło w ręce jego córek: Elżbiety, Jadwigi i Anny20.

Dzieciom Pawła Garwaskiego i Elżbiety Kucieńskiej przypadła więc trzecia część dóbr kutnowskich. Nie znamy niestety ani ów-

20 Por. B on i e cki, Herbarz, t. V, s. 90-91; T. N ow a k, op. cit., s. 142-145; T. Sławiński, Kretkowscy $i$ ich dzieje od połowy XIV wieku, WarszawaSkrzeszew 2011, s. 77, 134. W uzupełnieniu dodajmy, że nie jest pewne, czy Elżbieta $z$ Kucieńskich Garwaska przeżyła swoja matkę - Jadwigę $z$ Łaska. Można więc przypuszczać, że w późniejszych układach o podział dóbr kutnowskich uczestniczyły raczej jej nieletnie dzieci reprezentowane przez stryja, kanclerza gnieźnieńskiego Hieronima Garwaskiego. 
czesnego składu tego klucza, ani też sposobu, w jaki został on podzielony między spadkobierców młodszej linii rodu Kucieńskich. Zanim jednak spróbujemy oszacować wielkość schedy, którą przejęli wówczas Garwascy, musimy dokonać kilku istotnych korekt $\mathrm{w}$ genealogii tej rodziny. $\mathrm{W}$ dotychczasowej literaturze przedmiotu przyjmowano bowiem, że kasztelan sierpski Paweł Garwaski miał tylko dwóch synów: Stanisława i Pawła. Obaj odnotowani zostali zreszta jako właściciele działów w Kutnie, co tylko potwierdza znany nam fakt, że byli synami Elżbiety Kucieńskiej. Jako właściciel części Kutna występował jednak również Jerzy Garwaski, co pozwala przypuszczać, że również on był synem Pawła i Elżbiety. Dodatkowym argumentem przemawiajacym za takim rozwiązaniem zagadki jego pochodzenia jest sformułowanie zawarte $\mathrm{w}$ napisanym w 1611 r. testamencie Stanisława Garwaskiego, jednego z synów kasztelana sierpskiego: „Pogrzeb mój [...] żeby bez wszelkich zgiełków, cicho i uczciwie odprawion być mógł. Za czym i gości wiele, żeby nie zapraszali, tylko Ich Moś[ciów] Pany Bracię moję rodzonych, synowców i synowic, siestrzeńców i siestrzenic rodzonych. A miasto orszaków gości, proszę, aby było ubogich co najwięcej...". Na tej podstawie możemy bowiem $z$ cała pewnościa stwierdzić, że Stanisław Garwaski miał co najmniej dwóch rodzonych braci, obu żyjących w chwili sporządzania przywołanego tu testamentu, i przynajmniej jedną zamężną siostrę, która zmarła przed $1611 \mathrm{r}$. Wszelkie watpliwości dotyczące pokrewieństwa Jerzego Garwaskiego ze Stanisławem i Pawłem Garwaskimi rozwiewa natomiast pochodzacy z $1622 \mathrm{r}$. wpis do akt kapituły katedralnej płockiej. Starszy syn Jerzego Garwaskiego $z$ jego drugiego małżeństwa - Jan, który objął właśnie kanonię w tej kapitule, przedstawił bowiem wymagany przez prawo wywód swoich przodków, w którym jako babkę ojczysta wskazał Elżbietę Kucieńską h. Ogończyk. To $z$ kolei pozwala nam sformułować jednoznaczne i niepodlegajace dyskusji stwierdzenie, że Jerzy Garwaski był synem kasztelana sierpskiego Pawła $z$ jego małżeństwa $z$ Elżbietą $z$ Kutna oraz rodzonym bratem późniejszych kasztelanów płockich - Stanisława i Pawła. Dodatkowym argumentem potwierdzajacym taka filiację jest wniesiony do ksiag grodu płockiego w 1577 r. pozew przeciwko Stanisławowi, Pawłowi i Jerzemu Garwaskim, synom kasztelana sierpskiego Pawła i braciom „między soba rodzonym”, o wypłatę oprawy wdowie po ich zmarłym bracie Janie. Okazuje się zatem, że Paweł i Elżbieta Garwascy mieli nie dwóch, a czterech synów. Córkami tej pary były natomiast Jadwiga, która wyszła za Adama Ro- 
ściszewskiego h. Junosza (zm. 1612), kasztelana raciąskiego, oraz Anna, norbertanka w Łęczycy, która zmarła przed 23 listopada $1611 \mathrm{r}$. Według autorów opracowań heraldyczno-genealogicznych zamężna córka kasztelana sierpskiego - Jadwiga $z$ Garwaskich Rościszewska - pozostawiła po sobie dwie córki: Jadwigę, która poślubiła Michała Olszyńskiego h. Pniejnia, sędziego grodzkiego i skarbnika wiskiego, oraz Urszulę, która wyszła za mąż za Jana Borkowskiego h. Junosza ${ }^{21}$. Informacje te pozostaja w sprzeczności ze sformułowaniem $z$ testamentu Stanisława Garwaskiego, który wyraźnie wspominał przecież nie tylko o swoich siostrzenicach, lecz także siostrzeńcach. Albo więc Adam i Jadwiga Rościszewscy, oprócz dwóch córek, mieli również co najmniej dwóch synów, którzy żyli jeszcze w 1611 r., ale zmarli wkrótce potem bezżennie i bezpotomnie, albo też (co wydaje się równie prawdopodobne) mowa tu o znanych heraldykom synach obu siostrzenic: Olszyńskiej i Borkowskiej, których określono mianem „siostrzeńców” kasztelana płockiego.

${ }^{21}$ Por. B o n i e cki, Herbarz, t. V, s. 378; U ruski, Herbarz, t. IV, s. 103; N i e s i e cki, Herbarz, t. IV, s. 76-77 (tu brak informacji o pokrewieństwie łączącym Stanisława i Pawła Garwaskich); t. VII, Lipsk 1841, s. 99 (tu o małżeństwie Michała Olszyńskiego z Jadwigą Rościszewska); t. X (dodatek), Lipsk 1842, s. 43 (tu o małżeństwie Jana Borkowskiego $z$ Urszulą Rościszewska); T. Nowak, op. cit., s. 145; Topographia coenobii Skapensis (Opis klasztoru w Skepem z XVII w.), Archiwum Diecezjalne w Płocku, rkps 115, s. 102, cyt. za: P.G. Ga s i orow s ki, Sanktuarium i klasztor $w$ Skeppem jako nekropolia, „Materiały do Dziejów Kultury i Sztuki Bydgoszczy i Regionu" 2003, t. VIII, s. 182; Wywody kanoników katedralnych płockich wypisane przez Adama Pszczółkowskiego z Akt kapituły katedralnej płockiej (sygn. 8-25), publikacja internetowa [dalej: Wywody kanoników płockich], kanonik Jan Garwaski, poz. 6, sygn. 9, k. 365; P. Gaw ron, A. Moniuszko, op. cit., s. 136 (tu o pozwie przeciwko braciom Stanisławowi, Pawłowi i Jerzemu Garwaskim wniesionym do ksiag grodu płockiego. Ustalenia autorów na podstawie: Archiwum Główne Akt Dawnych w Warszawie [dalej: AGAD], Płockie grodzkie, wieczyste [dalej: PGW], ks. 66, k. 25-26). Nowe światło na genealogię Garwaskich rzuca też bałamutny wpis do ksiąg grodzkich łęczyckich dokonany w 1610 r., gdzie wspomniano o Jerzym Garwaskim, mieczniku gostynińskim, oraz o jego dzieciach: Stefanie, kasztelanie płockim, Pawle, staroście wyszogrodzkim, i Annie, norbertance łęczyckiej. W rzeczywistości chodzi tu o cześnika gostynińskiego Jerzego Garwaskiego oraz jego braci: Stanisława, kasztelana płockiego, i Pawła, starostę wyszogrodzkiego, oraz siostrę Annę, zakonnicę. Por. AGAD, Łęczyckie grodzkie, inskrypcje [dalej: ŁGI], ks. 119, k. 62v-63. Informację tę, podobnie jak szereg innych wypisów źródłowych dotyczacych rodziny Garwaskich, przekazała mi Pani dr Hanka Żerek-Kleszcz, której składam w tym miejscu serdeczne podziękowanie. 
Najstarszym synem kasztelana sierpskiego, urodzonym pewnie krótko przed 1550 r., był wspomniany Jan (zm. 1576), który otrzymał imię po dziadku ojczystym, cześniku płockim Janie. Nie wiemy o nim nic więcej poza tym, że ożenił się około roku $1575 \mathrm{r}$. i zmarł bezpotomnie już $\mathrm{w}$ roku następnym. Nie znamy również niestety ani imienia, ani też nazwiska jego owdowiałej małżonki22.

Stanisław Garwaski (zm. 1613), który otrzymał imię po dziadku macierzystym, wojewodzie rawskim Stanisławie Kucieńskim, był drugim synem kasztelana Pawła, urodzonym zapewne około $1551 \mathrm{r}$. Nie wiemy niestety nic o jego młodości. Możemy jednak śmiało założyć, że opiekujący się Stanisławem oraz jego młodszym rodzeństwem stryj Hieronim, kanclerz gnieźnieński, zadbał o staranne wykształcenie swoich bratanków. Być może zaraz po powrocie ze studiów zagranicznych w 1573 r. Stanisław Garwaski zaciagnał się do wojska jako rotmistrz jazdy koronnej. Ze służby wojskowej zrezygnowal jednak $\mathrm{w}$ roku następnym. Wcześnie też najstarszy $z$ trzech pozostałych przy życiu synów kasztelana sierpskiego związał swoje losy $z$ Janem Zamoyskim. Już 15 października 1574 r. pisał $z$ Kutna do przyszłego kanclerza, którego nie znał jeszcze osobiście, informujac go o zamordowaniu pozostającego w służbie Zamoyskiego Piotra Kucieńskiego $z$ Łąkoszyna. Swoje związki $z$ panem na Zamościu zacieśnił w dobie panowania Stefana Batorego. Był uczestnikiem zjazdu elekcyjnego w 1575 r., a po elekcji króla Stefana (15 grudnia) został powołany w skład poselstwa wysłanego przez stany Rzeczypospolitej do elekta $z$ powiadomieniem o wyborze. $Z$ rąk Stefana Batorego otrzymał nominację na godność sekretarza królewskiego. W 1584 r. został wybrany deputatem do Trybunału Koronnego. W roku następnym posłował na sejm $z$ województwa łęczyckiego. Wielka karierę polityczna zrobił jednak Garwaski dopiero za panowania Zygmunta III Wazy. W czasie elekcji 1587 r. należał do grona najbardziej oddanych stronników kanclerza wielkiego koronnego Jana Zamoyskiego. Podobnie jak jego patron, opowiedział się za wyborem królewicza szwedzkiego. Wyrażane wówczas sympatie polityczne ściagnęły na niego poważne kłopoty, gdyż 13 sierpnia 1587 r. w Warszawie „kilku tych nowotnych cudzoziemców na przedmieściu strzeliło [do niego], dlatego podobno, że w czarnej sukni był" (czarne szaty przybrali manifestacyjnie na znak żałoby po Batorym członkowie stronnictwa

22 Por. P. Gawron, A. Moniuszko, op. cit., s. 136 (na podstawie: AGAD, PGW, ks. 66, k. 25-26). 
kanclerskiego). Po wyborze Zygmunta na króla polskiego (19 sierpnia 1587 r.) Stanisław Garwaski wszedł w skład poselstwa kasztelana podlaskiego Marcina Leśniowolskiego, wysłanego do Szwecji z zawiadomieniem o elekcji nowego władcy. Po przybyciu orszaku młodego Wazy do Gdańska $z$ sędzią ziemskim kaliskim Świętosławem Orzelskim został wysłany przez króla-elekta do Krakowa, gdzie przywiózł tekst jego przysięgi, potwierdzenie praw Rzeczypospolitej oraz zaprzysiężone zobowiązania nowego władcy (pacta conventa). Brał następnie udział, jako poseł województwa płockiego, w sejmie koronacyjnym. W dniu koronacji Zygmunta III, 27 grudnia 1587 r., z dwoma innymi posłami płockimi - Szczęsnym (Feliksem) Kryskim i Pawłem Kossobudzkim - oraz trzema posłami mazowieckimi - Janem Iłowskim, Janem Podoskim i Mikołajem Żochowskim - złożył w grodzie krakowskim protest przeciwko konfederacji warszawskiej o pokoju religijnym, przeciwko podejmowanym przez stronę protestancką próbom uzyskania gwarancji prawnych, przewidujących podjęcie stosownych działań przeciwko osobom gwałcącym jej postanowienia oraz przeciwko zaprzysiężeniu przez króla aktu tej konfederacji (23 stycznia 1588 r. protestacja ta została wpisana do ksiag kancelarii koronnej, a 26 lutego 1588 r. Garwaski, występując w imieniu składających protest w dniu 27 grudnia 1587 r. katolickich senatorów i szlachty, działając wespół $z$ referendarzem koronnym Janem Tarnowskim, występującym w imieniu duchowieństwa, otrzymał dodatkowo królewskie potwierdzenie oblatowania aktu tej protestacji w księgach kancelarii koronnej). W czasie obrad sejmowych został powołany do deputacji do sądzenia maksymilianistów winnych rozerwania elekcji i wojny domowej. Wkrótce po zakończeniu sejmu koronacyjnego 24 lutego 1588 r. Stanisław Garwaski, dworzanin i sekretarz królewski, otrzymał od Zygmunta III pierwszą nagrodę - pensję w wysokości 700 złotych $z$ dochodów starostwa człuchowskiego (trzymał je wówczas Stanisław Latalski), która miał odbierać każdego roku w maju, w dniu św. Stanisława. Przy tej okazji wspomniano, że zasłużył się on podczas elekcji, towarzyszył królowi w podróży do Gdańska, a później do Krakowa (co nie do końca odpowiadało stanowi faktycznemu) oraz pracował w archiwum Królestwa przy wystawianych przez Zygmunta III potwierdzeniach praw. W tym samym roku został wysłany, $z$ Eliaszem Pielgrzymowskim, jako komisarz królewski do Inflant $\mathrm{w}$ celu odebrania przysięgi 
wierności od tej prowincji. Za pomyślne wywiązanie się $z$ tego zadania w 1589 r. otrzymał starostwo gostynińskie ${ }^{23}$.

Na sejm jesienny 1590 r. przybył Stanisław z młodszym bratem Pawłem. Obaj zostali wybrani posłami $z$ województwa płockiego przez dwa zwalczajace się stronnictwa - zwolenników i przeciwników kanclerza Jana Zamoyskiego. Stanisław był elektem obozu kanclerian. W czasie rugów poselskich obaj bracia zostali jednak pozbawieni swoich mandatów i musieli wrócić do domu. Na sejmie inkwizycyjnym 1592 r. Garwaski potwierdził swoje przywiąanie do wiary katolickiej i wrogość wobec innowierców. Kiedy bowiem protestanccy senatorowie i posłowie zażądali podjęcia prac nad uchwaleniem aktów wykonawczych do konfederacji warszawskiej i stanęli w obronie prześladowanych współwyznawców (w 1591 r. doszło do zburzenia zborów protestanckich w Wilnie i w Krakowie), to starosta gostyniński $z$ Lwem Sapiehą przypuścił gwałtowny atak na rzeczników sprawy innowierczej. Był bez watpienia jednym $z$ tych posłów ziemskich, którzy przyczynili się do tego, że sejm $1592 \mathrm{r}$. rozszedł się bez uchwalenia konstytucji. Garwaski posłował też na sejm 1593 r. i 15 czerwca jako poseł gostyniński podpisał zgodę na

23 Por. B on i e cki, Herbarz, t. V, s. 378; U ruski, Herbarz, t. IV, s. 103; Ni e s i e cki, Herbarz, t. IV, s. 76; M. Ple w c zyńs ki, Wojny i wojskowość polska $w$ XVI wieku, t. II (Lata 1548-1575), Zabrze-Tarnowskie Góry 2012, s. 327; P. Gaw ron, A. Moniuszko, op. cit., s. 136, 138; S. Garwaski do J. Zamoyskiego, Kutno 15 X 1574, Archiwum Jana Zamoyskiego, kanclerza $i$ hetmana wielkiego koronnego [dalej: AJZ], t. I (1553-1579), wyd. W. Sobieski, Kraków 1904, nr 62, s. 79-81; T. Now a k, op. cit., s. 145; Posłowie koronni, s. 283 (tu błędna data śmierci Stanisława Garwaskiego), 301; Vol. leg., t. II, s. 260; Świętosława Orzelskiego bezkrólewia ksiag ośmioro 1572-1576, wyd. E. Kuntze, Scriptores rerum polonicarum [dalej: SRP], t. XXII, Kraków 1917, s. 479; A. B a t o w s k i, Przeglad rzeczy opisanych $w$ VIII księgach rekopismu S. Orzelskiego: Dzieje pierwszych dwóch bezkrólewiów, „Biblioteka Naukowego Zakładu imienia Ossolińskich, pismo poświęcone dziejom, bibliografii, rozprawom i wiadomościom naukowym" 1843, t. VIII, s. 202; F. S i a r c zyń s k i, Obraz wieku panowania Zygmunta III króla polskiego i szwedzkiego zawierajacy spis osób żyjacych pod jego panowaniem, cz. 1, Lwów 1828, s. 132; E. O palińs ki, op. cit., s. 57; AGAD, Metryka Koronna [dalej: MK] nr 134, k. 62-64v, 207-207v, 217v-219v; H. W i s n e r, Zygmunt III Waza, Wrocław-Warszawa-Kraków 1991, s. 27; M. K o r o 1 k o, Klejnot swobodnego sumienia. Polemika wokót konfederacji warszawskiej $w$ latach 1573-1658, Warszawa 1974, s. 94; K. Le p s zy, op. cit., s. 291; K. P e łk a, op. cit. (z błędami, m.in. zdaniem autorki S. Garwaski został nagrodzony starostwem gostynińskim za bliżej nieokreśloną wyprawę, której celem było przyjęcie przysięgi wierności od króla); e a d e m, Senatorowie płoccy $w$ latach panowania Zygmunta III Wazy 1587-1632, „Rocznik Mazowiecki” 2009, R. XXI, s. 37-38 (z powieleniem tych samych błędów). 
wyjazd króla do Szwecji. Uczestnicząc w obradach sejmu 1595 r. (ponownie jako reprezentant ziemi gostynińskiej), 17 marca odpowiadał w imieniu katolików posłom protestanckim w sprawie złożonych przez nich dezyderatów. Został też deputatem izby poselskiej do spraw obrony. W 1596 r. Stanisław Garwaski wszedł w skład komisji do rokowań z posłami cesarskimi w sprawie przymierza przeciw Turkom. W początkach stycznia 1597 r. uczestniczył w sejmiku przedsejmowym w Raciążu, gdzie został powołany do deputacji układającej instrukcje dla wybranych tu posłów województwa płockiego (jednym $z$ nich był jego młodszy brat Paweł). W 1598 r. posłował na sejm $z$ ziemi wyszogrodzkiej. W roku następnym został wybrany deputatem na Trybunał Koronny. W 1600 r. uzyskał natomiast mandat poselski $z$ ziemi gostynińskiej. W tym samym roku, najpewniej w czasie obrad sejmu, wynagradzając go za rozliczne posługi dla Rzeczypospolitej, Zygmunt III obdarzył go urzędem kasztelana płockiego. W 1601 r., już jako senator, wszedł do sejmowej deputacji do korektury praw. Będąc zdecydowanym regalista, w okresie otwartej wrogości między królem a kanclerzem Zamoyskim, utrzymywał $z$ tym ostatnim bardzo poprawne stosunki. W 1602 r. zabiegał o protekcję kanclerza dla brata Pawła, dla którego starał się zdobyć nadanie jakiejś królewszczyzny lub lenna w Inflantach. Po śmierci Zamoyskiego zacieśnił swoje zwiąki $z$ obozem regalistycznym. W dobie rokoszu sandomierskiego odegrał pewna rolę, pośrednicząc jako regalista między Mikołajem Zebrzydowskim, $z$ którym łączyła go dawna znajomość $z$ okresu przynależności do obozu kanclerskiego, a stronnikami króla. Był obecny na zjeździe stężyckim w kwietniu 1606 r. W czerwcu tego roku towarzyszył Zygmuntowi III w jego podróży $z$ Warszawy do Krakowa. $Z$ innymi senatorami płockimi - biskupem Wojciechem Baranowskim i wojewoda Stanisławem Krasińskim - działał na rzecz utrzymania szlachty tego województwa w posłuszeństwie dla króla. Uczestniczył jeszcze w obradach sejmu 1609 r. Później podupadł na zdrowiu i znacznie ograniczył swoją działalność publiczną. W 1610 r. zrezygnowal ze starostwa gostynińskiego na rzecz brata Jerzego. W roku 1611 sporządził wspomniany testament. Zmarł w 1613 r. i został pochowany w podziemiach klasztoru bernardynów w Skępem²4.

${ }^{24}$ Por. B o nie cki, Herbarz, t. V, s. 378; U ruski, Herbarz, t. IV, s. 103; Nie si e cki, Herbarz, t. IV, s. 76; K. Le pszy, op. cit., s. 291-292; id e m, Rzeczpospolita Polska $w$ dobie sejmu inkwizycyjnego (1589-1592), Kraków 1939, 
Stanisław Garwaski zgromadził w swoim ręku znaczny majatek. Na początku ósmej dekady XVI w., więc $z$ całą pewnościa jeszcze przed dokonaniem ostatecznego podziału dóbr ziemskich po rodzicach, odnotowano jego własność w części Kutna oraz w przyległych wioskach: Gnojenku i Podczachach. $Z$ dawnych majętności ojcowskich wzią zapewne Miszewo (Miszewko Garwaskie), wójtostwo w Bodzanowie i część Małoszewa (w powiecie płockim) oraz Krawięczyn (w ziemi wyszogrodzkiej). Po śmierci stryja Hieronima w 1583 r. objął też przypuszczalnie połowę Woli Młockiej (w powiecie niedzborskim na Zawkrzu). W rejestrach poborowych województwa płockiego $z 1578 \mathrm{r}$. oraz województwa mazowieckiego $\mathrm{z}$ roku $1576 \mathrm{w}$ starych posiadłościach rodowych usytuowanych w pobliżu Bodzanowa wykazano odpowiednio: 6, 4, 10 (część włók należała jednak zapewne do Rybskich) i 12,5 łana. W Woli Młockiej było w tym czasie około 15 łanów kmiecych, z czego na część Stanisława przypadło około 7,5 łana. Razem więc dział późniejszego kasz-

s. 408; K. Ty s z kow s k i, Poselstwo Lwa Sapiehy do Moskwy, Lwów 1927, s. 46; F. Siarczyński, op. cit., s. 132; P. Gawron, A. Moniuszko, op. cit., s. 139-140; Posłowie koronni, s. 332, 342, 354, 363, 369, 392, 404; Diariusze sejmowe R. 1597. W dodatkach akta sejmikowe $i$ inne odnoszace sie do tego sejmu [dalej: Diariusz 1597], wyd. E. Barwiński, SRP, t. XX, Kraków 1907, s. 241, 359; J. W i e le w i cki, Dziennik spraw domu zakonnego OO. Jezuitów u ś. Barbary w Krakowie od r. 1579 do r. 1599 (włącznie), ibidem, t. VII, Kraków 1881, s. 157; W. Ty g i e $1 \mathrm{~s} \mathrm{k} \mathrm{i,} \mathrm{W} \mathrm{poszukiwaniu} \mathrm{patrona,} \mathrm{„Przegląd} \mathrm{Historyczny”} \mathrm{1987,} \mathrm{t.} \mathrm{LXXVIII,}$ z. 2, s. 202; J. Choiń s ka-M ika, Sejmiki mazowieckie $w$ dobie Wazów, Warszawa 1998, s. 122, 156, 180; K. P ełk a, Senatorowie płoccy..., s. 37-38; e a d e m, Kariera braci... (z błędami - zdaniem autorki sejm inkwizycyjny obradował w latach 1589-1592; nie podaje ona także nawet przybliżonej daty śmierci Stanisława Garwaskiego); P.B. G a s i o row ski, op. cit., s. 182 (z poprawna data śmierci Stanisława Garwaskiego); J. M a c is ze w s ki, Wojna domowa $w$ Polsce (1606-1609). Studium $z$ dziejów walki przeciw kontrreformacji, cz. 1 (Od Stężycy do Janowca), Wrocław 1960, s. 113, 304. Jako ciekawostkę warto w tym miejscu przytoczyć absurdalne wręcz informacje na temat Stanisława Garwaskiego zawarte $\mathrm{w}$ opracowaniu cieszącym się ogromnym, acz niezasłużonym powodzeniem wśród genealogów-amatorów, czyli w Wielkiej Genealogii Minakowskiego. Powołujac się na herbarz A. Bonieckiego oraz biogram Garwaskiego zamieszczony w PSB, autor ten stwierdza, że Stanisław Garwaski, syn Pawła, kasztelana sierpskiego, oraz N. Kucieńskiej, starosta gostyniński i kasztelan płocki, urodził się około 1550 r., ale zmarł już w 1560 r. (data taka rzeczywiście widnieje na początku jego biogramu w $P S B$, ale jest to data zgonu jego ojca!). Śmierć w wieku 10 lat nie przeszkodziła mu jednak rzecz jasna w zrobieniu kariery politycznej i w sięgnięciu w późniejszym okresie po wspomniane urzędy. Por. Stanisław Garwaski z Garwarza h. Grzymała (odm.) (ID: 5.959.12), [w:] M.J. M i n a k o w s k i, Wielka Genealogia Minakowskiego (Wielcy.pl) [dalej: WGM], dostęp: 23 X 2015 r. 
telana płockiego obejmował 2 wsie całe, wójtostwo oraz 2 części wsi $z$ około 35 łanami kmiecymi. W 1590 r. wykupił on jednak drugą część Małoszewa od Rybskich, co sprawiło, że obszar ról chłopskich w jego dobrach obejmował wówczas nie mniej niż 40 łanów. Miał też początkowo zapewne jakieś niewielkie udziały $\mathrm{w}$ dobrach kutnowskich, $\mathrm{z}$ których zrezygnował jednak $\mathrm{z}$ czasem na rzecz brata Jerzego. Na przełomie XVI i XVII stulecia nabył natomiast dawna majętność Kościeleckich, a następnie Mieleckich, czyli miasto Skępe z wsiami Wioska Skępska, Czermno, Wólka i Rzuchowo w powiecie lipnowskim w ziemi dobrzyńskiej. W latach 1589-1610 użytkował też dobra starostwa gostynińskiego (zamek, miasto, 5 wsi). Ze swoich dóbr spławiał zboże do Gdańska. Miał spichlerz w Brwilnie nad Wisła darowany mu w 1592 r. przez szwagra jego najmłodszego brata, kasztelana brzezińskiego Mikołaja Szczawińskiego. W związku ze spławem zboża oskarżano go także o nadużycia celne na komorze włocławskiej. Zgromadzony przez siebie majątek łożył na działalność dobroczynną oraz na pobożne fundacje. We wrześniu 1592 r., w czasie obrad sejmu inkwizycyjnego, współuczestniczył w założeniu, powstałego $z$ inicjatywy Piotra Skargi, Bractwa Miłosierdzia w Warszawie. W decydujacym stopniu przyczynił się do utworzenia podobnego bractwa w Lublinie. W latach 1599-1603 ufundował dla niego drewniany kościół i zespół szpitalny św. Łazarza na Podwalu koło bramy Grodzkiej. Po pożarze kościoła, który spłonał $\mathrm{w}$ czasie rokoszu sandomierskiego, był jednym $z$ fundatorów nowej, murowanej świątyni pod wezwaniem św. Wojciecha. Pod koniec życia ufundował też nowy kościół parafialny w Skępem (budowę kontynuowali jego spadkobiercy). Utrzymywał bliskie stosunki $z$ zakonem jezuitów. Był dobrodziejem ich kolegium we Lwowie oraz zapewne w Krakowie. Świadczył też łaski bernardynom w Skępem, którym zapisał m.in. swoją bibliotekę licząca ponad 50 woluminów. Spore sumy wyłożył także na przeprowadzona w początkach XVII w. restauracje zrujnowanego zamku w Gostyninie. Stanisław Garwaski był zręcznym politykiem. Przechodząc do obozu królewskiego, potrafił zachować poprawne relacje $z$ Janem Zamoyskim. Zdeklarowany katolik i wróg różnowierców, współpracował $z$ najwybitniejszymi przedstawicielami episkopatu: Janem Tarnowskim, Wojciechem Baranowskim, Wawrzyńcem Gembickim, Piotrem Tylickim, Marcinem Szyszkowskim i Filipem Wołuckim. Był bez watpienia tym przedstawicielem swojego rodu, który odegrał największą rolę na krajowej scenie 
politycznej. Stanisław Garwaski nie założył rodziny. Zmarł bezpotomnie, a jego dobra ziemskie odziedziczyli bracia ${ }^{25}$.

Paweł Garwaski (zm. 1618) był trzecim synem Pawła, kasztelana sierpskiego, i wojewodzianki rawskiej Elżbiety Kucieńskiej. Urodził się prawdopodobnie około 1553 r. Przez całe życie był blisko związany ze starszym bratem Stanisławem. O jego młodości brakuje informacji. Musiał jednak odebrać staranne wykształcenie. W 1576 r. został wspomniany jako dziedzic części Kutna. Na jego przyszła karierę największy wpływ wywarło bardzo korzystne małżeństwo, zawarte zapewne nie bez udziału stryja Hieronima. W 1579 r. Paweł Garwaski poślubił bowiem Dorotę Zielińska h. Świnka, najstarszą córkę Grzegorza, kasztelana płockiego, i Ewy Mdzewskiej h. Dołęga. $Z$ jej ręką otrzymał ogromny, jak na sto-

$25 \mathrm{~W}$ tym miejscu należy wyjaśnić, że nie znamy postanowień aktu, na mocy którego kasztelanice sierpscy dokonali podziału majątku po rodzicach. Wiemy jednak na pewno, że Jerzy wzią tylko majątki macierzyste w województwach rawskim i łęczyckim, a Paweł został właścicielem wsi Garwarz i Brochocin w województwie płockim, na których zabezpieczył w przyszłości posag swojej żony. Na dział Stanisława musiała zatem przypaść połowa dóbr rodowych w województwie płockim oraz w ziemi wyszogrodzkiej. Być może część tych majątków trzymał do swojej śmierci w 1583 r. stryj braci Garwaskich - Hieronim (w 1579 r. odnotowano np. jego własność w Woli Młockiej). Dopiero po zgonie kanclerza gnieźnieńskiego doszło też zapewne do ostatecznego uregulowania spraw majatkowych jego bratanków, $z$ których Stanisław objął dobra koło Bodzanowa, a Paweł pozostałe posiadłości rodowe. Obaj bracia podzielili też $z$ pewnością po połowie Wolę Młocka, która odziedziczyli po stryju. Por. T. N o w a k, op. cit., s. 145; Źródła dziejowe, t. XVI (Polska XVI wieku pod względem geograficzno-statystycznym t. V, Mazowsze), wyd. A. Pawiński, Warszawa 1895, s. 8, 116, 128, 301; J. Łe m picki, op. cit., t. I-II, s. 49 (tu informacja, że nabywca części Małoszewa od Rybskich był Paweł Garwaski); AGAD, ŁGI, ks. 85, k. 90-91 (tu o spichlerzu w Brwilnie - informacja przekazana mi przez dr H. Żerek-Kleszcz); P.B. G ą s i o r ow s ki, op. cit., s. 180 (tu informacja, że dobra skępskie nabył Garwaski dopiero około 1610 r.); G. Zi eliński, J. Z i elińs ki, Wiadomość historyczna o rodzie Świnków oraz rodowód pochodzacej od nich rodziny Zielinskich herbu Świnka, cz. 2 (Od roku 1600 do czasów obecnych), Torun 1881, s. 51 (tu skład dóbr skępskich w roku 1620), 362 (tu o zapisach na rzecz klasztoru bernardynów w Skępem); J. M a c i szew ski, op. cit., s. 323; M. B a li ńs ki, T. Li pińs ki, Starożytna Polska pod względem historycznym, jeograficznym $i$ statystycznym opisana, t. I, Warszawa 1843, s. 422; J. W i el e wi c ki, Dziennik spraw domu zakonnego OO. Jezuitów $u$ ś. Barbary $w$ Krakowie od roku 1600 do 1608 (włacznie), SRP, t. X, Kraków 1886, s. 166; Nie s i e cki, Herbarz, t. IV, s. 77; U ru s ki, Herbarz, t. V, s. 103 (tu błędna data śmierci - 1609 r. oraz bałamutna informacja, że Stanisław Garwaski pozostawił po sobie synów Jerzego i Mikołaja); K. P e łka, Kariera braci... (tu m.in. powtórzona za herbarzem Uruskiego błędna informacja o Jerzym i Mikołaju, którzy mieli być synami Stanisława Garwaskiego). 
sunki mazowieckie, posag wynoszący 10000 złotych, który oprawił (zwyczajowo w podwójnej wysokości, czyli w kwocie 20000 złotych) na dobrach Garwarz i Brochocin. Pozycja Garwaskiego wzmocniła się w roku 1582, kiedy jego teść otrzymał nominację na urząd wojewody płockiego. Od tej pory Grzegorz Zieliński nie ustawał $\mathrm{w}$ zabiegach o uzyskanie jakiegoś urzędu ziemskiego dla swojego zięcia. Przedmiotem jego starań było pisarstwo ziemskie płockie. Wojewoda pisał $\mathrm{w}$ tej sprawie do Jana Zamoyskiego. W marcu 1585 r. starania te zostały wsparte przez wojewodę mazowieckiego Stanisława Kryskiego (ciotecznego brata Grzegorza Zielińskiego), który gorąco zalecał kanclerzowi wielkiemu koronnemu służby Pawła Garwaskiego. Starania te zakończyły się jednak na razie niepowodzeniem, gdyż nominacja królewska przypadła Sebastianowi Kobiernickiemu. W 1585 r. Paweł Garwaski po raz pierwszy został wybrany na sejmiku województwa płockiego w Raciażu posłem na sejm. W czasie bezkrólewia po Stefanie Batorym włączył się aktywnie do działań podejmowanych przez szlachtę płocką. W czasie elekcji 1587 r. Garwaski, podobnie jak jego starszy brat, poparł kandydaturę Zygmunta III. We wrześniu tego roku został wyznaczony przez sejmik raciąski jako jeden $z$ przedstawicieli szlachty płockiej na zjazd wiślicki. Powołano go też wówczas do trzyosobowej deputacji (obok jego szwagra, kasztelana raciąskiego Adama Rościszewskiego i Mateusza Dobrskiego), która miała uwierzytelnić podjęta na sejmiku uchwałe poborowa przez zebranie podpisów obecnej w Raciążu szlachty. Dnia 26 kwietnia 1588 r. nowy król obdarzył go urzędem pisarza ziemskiego płockiego, wakujacym po śmierci Sebastiana Kobiernickiego. W 1589 r. Garwaski ponownie uzyskał mandat poselski na sejmiku w Raciążu. Jako poseł znalazł się w gronie sygnatariuszy podpisanego w dniu 9 marca traktatu bytomsko-będzińskiego $z$ Habsburgami. Na sejmie tym został wybrany na szafarza poborów w ziemi wyszogrodzkiej. We wrześniu 1589 r. staną na czele roty husarskiej wystawionej przez szlachtę płocka na wojnę przeciwko Turcji. Rota Garwaskiego weszła do służby 20 września 1589 r. i pozostała w niej przez dwa kwartały. Po tym okresie jej rotmistrz opuścił szeregi armii, odbierając należny żołd w wysokości 4300 złotych. Na sejm 1590 r. przybył ze starszym bratem Stanisławem, wybrany posłem na rozdwojonym sejmiku raciąskim. W czasie rugów poselskich nie uznano jednak wyników elekcji przeprowadzonej w Raciążu i obu Garwaskich nie dopuszczono do udziału w obradach. W 1593 r. dzięki zabiegom teścia, wojewody płockiego Grzegorza Zielińskiego, który 
doprowadził do rozdwojenia sejmiku deputackiego, Garwaski został deputatem na Trybunał Koronny. W tym samym roku ponownie został wybrany posłem na sejm $z$ województwa płockiego. Był bez wątpienia człowiekiem popularnym i cieszącym się zaufaniem współziomków. Mimo tego, że uwikłał się w aferę zwiąaną $z$ rozdwojeniem sejmiku deputackiego w 1593 r., we wrześniu 1594 r., na kolejnym sejmiku dokonującym wyboru deputatów na Trybunał Koronny (ponownie opanowanym przez zwolenników wojewody płockiego), złożył swój podpis pod tekstem uchwały „imieniem rycerstwa, proszony od tych, co pisać nie umieli" 26.

$\mathrm{W}$ latach następnych kontynuował $\mathrm{z}$ powodzeniem karierę parlamentarna. W 1596 r. został wybrany marszałkiem sejmiku raciąskiego. Posłował też $z$ województwa płockiego na sejmy w 1596, 1597 (na tym sejmie wszedł w skład komisji konstytucyjnej), 1598 (został wówczas deputatem prowincji wielkopolskiej do odbierania kwarty) i w 1600 r. W roku następnym został wybrany posłem z ziemi wyszogrodzkiej. W tym samym czasie rozpoczą zabiegi o powrót do służby wojskowej. W dniu 26 marca 1601 r. otrzymał list przypowiedni na 100 koni husarii oraz żołd za pierwszy kwartał służby. Po zakończeniu obrad sejmowych na czele sformowanej już roty ruszył do Inflant, gdzie dotarł pod koniec sierpnia $1601 \mathrm{r}$. Spędził tu następne półtora roku, walcząc w ramach pułku pozostającego pod bezpośrednią komenda hetmana wielkiego koronnego Jana Zamoyskiego. Brał udział w oblężeniach Wolmaru, Felina i Białego Kamienia. Po zakończeniu działań wojennych w Inflantach rota Garwaskiego, przystapiwszy do konfederacji wojskowej,

26 Por. AGAD, MK nr 134, k. 374-374v; B on i e cki, Herbarz, t. V, s. 378; T. Nowak, op. cit., s. 145; G. Zielińs ki, J. Zieliński, op. cit., cz. 1 (Od najdawniejszych czasów do roku 1600), Toruń 1880, s. 107, 109; K. L e p szy, Garwaski Stanisław, s. 292 (tu błędna informacja, że urząd pisarza ziemskiego płockiego otrzymał Garwaski już w 1585 r.); E. O paliń s ki, op. cit., s. 164 (tu błędna informacja, że żona Garwaskiego otrzymała 20000 złotych posagu); Stanisław Kryski do Jana Zamoyskiego, Płock 31 III 1585, AJZ, t. IV (1585-1588), wyd. K. Lepszy, Kraków 1948, s. 12-13; Posłowie koronni, s. 284, 314 (tu błędna informacja, że posłem na sejm 1589 r. był Stanisław, a nie Paweł Garwaski), 333, 351; W. Ty gi els k i, op. cit., s. 202; J. C h o ińs k a - M i k a, op. cit., s. 49, 63, 178 (tu błędna informacja, że P. Garwaski posłował na sejm koronacyjny w 1588 r.); Posłowie koronni, s. 284; Vol. leg., t. II, s. 303 (na sejmie 1589 r. Garwaski powołany do wybierania poborów w ziemi wyszogrodzkiej $-z$ błędnym imieniem Jan zamiast Paweł); K. P ełk a, Senatorowie płoccy..., s. 35, 38, 39 (tu błędnie o dacie nominacji Garwaskiego na pisarstwo płockie); e a d e m, Kariera braci... (z licznymi błędami); P. G aw ro n, A. M on iu s z k o, op. cit., s. 137-139. 
znalazła się na Rusi. Nie wydaje się jednak, by rotmistrz towarzyszył swoim podkomendnym. Najpewniej wrócił do domu i rozpoczął starania o przedłużenie służby. Początkowo myślał chyba o jej kontynuowaniu w Inflantach, gdyż w listopadzie 1602 r. jego starszy brat - kasztelan płocki Stanisław - zabiegał u Zamoyskiego o wynagrodzenie dotychczasowych służb Pawła i nadanie mu jakiejś królewszczyzny lub lenna w tej prowincji. W marcu 1603 r. Garwaski odebrał w Krakowie 1500 złotych zaległego żołdu. Pod koniec tego miesiąca, na prośbę Stanisława Garwaskiego, hetman polny koronny Stanisław Żółkiewski napisał list do Jana Zamoyskiego, proszac go o rotę kwarciana dla pisarza ziemskiego płockiego. Sądzić więc można, że Paweł Garwaski, zniechęcony do trudów wojny w Inflantach, postanowił kontynuować swoją służbę na kresach południowo-wschodnich. Odmowna odpowiedź Jana Zamoyskiego na listy obu protektorów Pawła Garwaskiego sprawiła jednak, że ten ostatni definitywnie zrezygnował $z$ kariery wojskowej. W 1605 r. Garwaski ponownie został wybrany posłem na sejm z ziemi wyszogrodzkiej. W tym samym roku marszałkował sejmikowi województwa mazowieckiego w Warszawie, a następnie wziął udział w obradach sejmowych. W czasie rokoszu Zebrzydowskiego, podobnie jak jego starszy brat, opowiedział się zdecydowanie po stronie Zygmunta III. W lutym 1606 r. został wybrany posłem na opanowanym przez regalistów sejmiku w Raciażu. Jego postawa została dostrzeżona i doceniona na dworze. W tym samym roku otrzymał bowiem nominację na urzą starosty grodowego wyszogrodzkiego. W 1607 r. ponownie reprezentował ziemię wyszogrodzka na sejmie w Warszawie. Po raz ostatni uzyskał mandat poselski na rozdwojonym sejmiku płockim w 1611 r. Na sejmie obradujacym $\mathrm{w}$ tym samym roku został jednym $z$ komisarzy wyznaczonych do rokowań $z$ państwem moskiewskim oraz do rozliczeń $z$ żołnierzami. W roku następnym towarzyszył królowi w jego nieudanej wyprawie na Moskwę. W 1613 r. został kasztelanem sierpskim. W 1616 r., po śmierci Wojciecha Kryskiego, otrzymał nominację na kasztelanię płocka. W tym samym roku zrezygnował ze starostwa wyszogrodzkiego na rzecz podkomorzego płockiego Jana Stanisława Karnkowskiego. Zmarł w 1618 r. i został pochowany w podziemiach klasztoru bernardynów w Skępem²7.

27 Por. K. Le p s zy, Garwaski Stanisław, s. 292 (tu m.in. błędna informacja, że Paweł Garwaski posłował na sejm w 1608 r. W rzeczywistości w roku 1608 sejm nie obradował); W. Ko n o p c zyńs ki, Chronologia sejmów polskich 1493- 
Paweł Garwaski był człowiekiem zamożnym. W dziale majątku po rodzicach wziął Garwarz i Brochocin oraz połowę Przeciszewa. Po stryju Hieronimie dostał przypuszczalnie połowę Woli Młockiej. Miał też zapewne jakieś udziały w dobrach kutnowskich, $z$ których jednak zrezygnował $z$ czasem na rzecz brata Jerzego. W pochodzacym $z 1578$ r. rejestrze poborowym województwa płockiego wykazano w Garwarzu 11, w Brochocinie 11, w połowie Przeciszewa 5, a w połowie Woli Młockiej około 7,5 łana kmiecego. W podzielonej na pięć części Wkrze nie odnotowano już natomiast $\mathrm{w}$ tym czasie własności Garwaskich. Swoja część tej wioski musieli oni zatem sprzedać w okresie, kiedy kuratelę nad bratankami sprawował ksiądz Hieronim. W dobrach, które przypadły Pawłowi, znajdowało się więc około 34,5 łana kmiecego i była to wielkość zbliżona do areału ziemi chłopskiej $\mathrm{w}$ dobrach należących $\mathrm{w}$ tym czasie do Stanisława Garwaskiego (35 łanów). Zadłużywszy swoje dobra, w 1597 r. zmuszony był jednak sprzedać Brochocin biskupowi (ówcześnie przemyskiemu, następnie zaś poznańskiemu) Wawrzyńcowi Goślickiemu. Po śmierci starszego brata Stanisława w roku 1613 Paweł Garwaski odziedziczył połowę jego majątku. W wyniku

1793, Kraków 1948, s. 20; B o n i e c ki, Herbarz, t. V, s. 378; N ie s i e c ki, Herbarz, t. IV, s. 77; J. Choińs ka-Mika, op. cit., s. 69, 156, 158, 178; Posłowie koronni, s. 369, 379 (tu błędna informacja, że na sejmie 1597 r. Paweł Garwaski został deputatem do odbierania kwarty z Wielkopolski), 392, 401; Diariusz 1597, s. 355; J. R z oń c a, Sejmy z lat 1597-1598, cz. 1 (Bezowocny sejm z 1597 roku), Warszawa-Wrocław 1989, s. 107-108; Vol. leg., t. II, s. 379; S. H e r b s t, Wojna inflancka 1600-1602, wyd. 2, Zabrze 2006, s. 117, 138, 141; H. W is n e r, Kircholm 1605, Warszawa 2011, s. 80, 87-88; P. Gaw ron, A. M onius zko, op. cit., s. 137-140; P. G a w r o n, Proces tworzenia kadry oficerskiej armii koronnej $w$ czasach Zygmunta III Wazy (1587-1632), [w:] Organizacja armii $w$ nowożytnej Europie. Struktura - urzędy - prawo - finanse, red. K. Łopatecki, Zabrze 2011, s. 253; W. Ty gi e $1 \mathrm{~s} \mathrm{k} \mathrm{i,} \mathrm{op.} \mathrm{cit.,} \mathrm{s.} \mathrm{202;} \mathrm{K.} \mathrm{P} \mathrm{ełk} \mathrm{a,} \mathrm{Senatorowie} \mathrm{płoccy...,} \mathrm{s.} \mathrm{38-39}$ (z licznymi błędami - m.in. Garwaski miał posłować na sejm 1608 r., a w roku 1609 został mianowany [sic!] marszałkiem sejmiku generalnego); e a d e m, Kariera braci... (z kuriozalnymi błędami - m.in. Garwaski posłował na sejm 1608 r.; został mianowany [sic!] marszałkiem sejmiku generalnego w 1609 r.; cytat $z$ listu S. Kryskiego do J. Zamoyskiego z 1585 r. włączony do streszczenia listu S. Garwaskiego do J. Zamoyskiego z 1602 r. itp.); V. U r b a n i a k, Zamoyszczycy bez Zamoyskiego. Studium dekompozycji ugrupowania politycznego, Warszawa 1995, s. 49; H. W is n e r, Dyplomacja polska w latach 1572-1648, [w:] Historia dyplomacji polskiej, t. II (1572-1795), red. Z. Wójcik, Warszawa 1982, s. 64; Vol. leg., t. III, Petersburg 1859, s. 5; A. Przy b o ś, Karnkowski Jan Stanisław, [w:] PSB, t. XII, Wrocław-Warszawa-Kraków 1966-1967, s. 76; AGAD, MK nr 151, k. 7273; nr 160, k. 99v-100; P.B. G ą s i o r ow s ki, op. cit., s. 188. 
rozliczeń $z$ najmłodszym bratem Jerzym stał się właścicielem wszystkich dóbr rodowych położonych na prawym brzegu Wisły, więc własnych: Garwarza, połowy Przeciszewa i połowy Woli Młockiej, jak również przejętych po zgonie brata: Miszewa, Małoszewa, wójtostwa w Bodzanowie i drugiej połowy Woli Młockiej w województwie płockim, Krawięczyna w ziemi wyszogrodzkiej oraz miasta Skępego z wsiami Wioska Skępska, Czermno, Wólka i Rzuchowo w ziemi dobrzyńskiej. Jego majątek obejmował więc wówczas 1 miasto, 1 wójtostwo, 9 wsi całych i 1 część wsi. Dodajmy do tego, że w latach 1606-1616 Garwaski użytkował też dobra starostwa wyszogrodzkiego (zamek, miasto, 7 wsi, 4781 florenów rocznego przychodu według lustracji z 1617 r.). Mimo posiadania znacznej fortuny kasztelan płocki niemal przez całe życie borykał się $z$ różnego rodzaju trudnościami finansowymi. $Z$ tego powodu zmuszony był odprzedać starostwo wyszogrodzkie Janowi Stanisławowi Karnkowskiemu. Zaciągał też znaczne pożyczki (m.in. na kontynuowanie budowy ufundowanego przez Stanisława Garwaskiego kościoła parafialnego w Skępem), którymi obciążał swoje dobra. Pod względem wpływów politycznych i znaczenia nigdy nie zdołał dorównać najstarszemu bratu. $Z$ małżeństwa $Z$ wojewodzianka płocką Dorotą Zielińska pozostawił czworo dzieci: córki Katarzynę i Dorotę oraz synów Hieronima i Jana 28 .

28 Wychodząc $z$ założenia, że Stanisław i Paweł Garwascy otrzymali równe działy $z$ dóbr po ojcu, wydaje się niemal pewne, że scheda Pawła, oprócz Garwarza i Brochocina, obejmowała również połowę Przeciszewa w powiecie bielskim. Po śmierci stryja Hieronima w 1583 r. objął on też zapewne połowę położonej nieopodal Garwarza Woli Młockiej. W rejestrze poborowym z $1578 \mathrm{r}$. wykazano tu 12 łanów będących własnościa Hieronima Garwaskiego oraz 2 5/8 łana należącego do innego właściciela (być może mowa tu o części będącej niegdyś własnościa Pawła Garwaskiego, kasztelana sierpskiego). Por. Źródła dziejowe, t. XVI, s. 6, 23, 116; SGKP, t. XIII, s. 792; P. G a w r o n, A. M o n i u s z k o, op. cit., s. 136. Wspomniani tu autorzy, określajac wielkość majątku Pawła Garwaskiego, popełnili jednak szereg istotnych błędów. Najpoważniejszym $z$ nich było uznanie, że wszystkie dobra Garwaskich w województwie płockim i w ziemi wyszogrodzkiej były własnościa Pawła Garwaskiego. Błędnie określono także rozmiary własności Garwaskich w Przeciszewie - cała wieś (zamiast połowa wsi). Niesłusznie przypisano też Garwaskim własność części Glinojecka (nie mieli tu nigdy żadnej osiadłości) oraz części Bodzanowa (w rejestrze poborowym województwa mazowieckiego z 1576 r. wyraźnie zaznaczono, że miasteczko i jego przedmieście stanowią własność klasztoru norbertanek pw. św. Marii Magdaleny w Płocku - Źródła dziejowe, t. XVI, s. 128-129). Brakuje natomiast informacji o tym, że Garwascy byli właścicielami wójtostwa w Bodzanowie, gdzie odnotowano 4 łany. Nieprawdziwe jest również stwierdzenie, że w rejestrze poborowym województwa płockiego nie 
Hieronim Garwaski (zm. 1620) - starszy syn kasztelana płockiego Pawła - niewiele przeżył ojca. Nie piastował żadnych urzędów. Nie założył też rodziny. Zmarł już w 1620 r. (przed 10 sierpnia) i został pochowany, podobnie jak stryj i ojciec, w podziemiach klasztoru bernardynów w Skępem. Po śmierci Hieronima cała fortuna kasztelana płockiego przeszła w ręce jego młodszego syna Jana (zm. 1624). Szybko miało się jednak okazać, że dobra po Pawle Garwaskim obciaż̇one były pokaźnymi długami, z których spłata Jan nie potrafił sobie poradzić. W tej sytuacji wkrótce po śmierci brata, 10 sierpnia 1620 r., zdecydował się sprzedać dobra skępskie swojemu wujowi, kasztelanowi płockiemu Walentemu Zielińskiemu. Jako powód zbycia Skępego z przyległościami podano, „iż Jmść Pan Garwaski, mając na majętnościach swych wszystkich, tak w Województwie Płockim, jako i w Ziemi Dobrzyńskiej leżących, niemałe długi, onera, trudności i przewody prawne $z$ fundamentów przodków swych Wielmożnych P.P. Stanisława stryja, Pawła ojca Garwaskich Kasztelanów Płockich i Pana Hieronima Garwaskiego, teraz niedawno zeszłego brata swego i prywatnych też nieco swoich zawiedzione, których żadna miara podźwignać, znieść i ułacnić sam przez się nie mogąc (gdyż pewne osoby chciwościa majętności jego ułapić, uwiedzenie prawa i przezyski na nim kupowali) Wgo Jmść Pana Płockiego, wuja swego rodzonego, wielokroć ustnemi i przez powinne prośbami swemi częstemi używał i suplikował, aby go w tak wielkich trudnościach i zawodach przez niego niepodźwignionych ratować i majętność Skępska, na eliberatia tych ciężarów od niego wiecznościa przyją..." Za miasto Skępe oraz wchodzace w skład klucza wsie Wioska Skępska, Czermno, Wólka i Rzuchowo kasztelan płocki zapłacić miał formalnie 28000 złotych. Dodatkowa umowa zawarta między stronami przewidywała jednak, że Garwaski otrzyma ex nunc w gotówce

uwzględniono Miszewa Garwaskiego - w rzeczywistości wieś ta została odnotowana na s. 8 cytowanego wcześniej tomu Źródeł dziejowych; J. Łe m p i c ki, op. cit., t. I-II, s. 14. W innych kwestiach por. G. Zieliński, J. Zieliński, op. cit., cz. 2, s. 51. B o n i e cki, Herbarz, t. V, s. 378; U ru s k i, Herbarz, t. IV, s. 103; K. Le p s zy, Garwaski Stanisław, s. 292; A. Przy b o ś, Karnkowski Jan Stanisław, s. 76; Lustracje województwa mazowieckiego XVII wieku, cz. 1 (16171620), wyd. A. Wawrzyńczyk, Wrocław-Warszawa-Kraków 1968, s. 3-17. Por. też Paweł Garwaski z Garwarza h. Grzymała (odm.) (ID: 5.959.13), [w:] WGM, dostęp: 23 X 2015 r. (tu błędna informacja, że Paweł Garwaski był przyrodnim bratem kasztelana płockiego Stanisława, a imię i nazwisko jego matki - domniemanej drugiej żony kasztelana sierpskiego Pawła - jest nieznane). 
jedynie 5000 złotych (w rzeczywistości suma ta musiała być znacznie mniejsza, gdyż potrącono $z$ niej pożyczki zaciagnięte u wuja przez Hieronima i Jana Garwaskich), a pozostałe 23000 złotych Walenty Zieliński wypłacać miał w ratach, w miarę zgłaszania się wierzycieli kasztelanica płockiego, przy czym w pierwszej kolejności miały być regulowane długi ciążące na majętności skępskiej, a dopiero później te, które były zabezpieczone na mazowieckich dobrach Jana Garwaskiego. Ten ostatni zobowiązał się również do niezaciagania nowych długów, nieobciążania nimi swoich posiadłości oraz niezbywania żadnych majętności bez wiedzy i zgody Walentego Zielińskiego. O młodszym kasztelanicu płockim wiemy ponadto, że ożenił się z Izabelą Karnkowską h. Junosza, córką wojewody płockiego Jana Stanisława i Zofii $z$ Rokszyckich h. Pobóg. Małżeństwo to było bezdzietne. Jan Garwaski zmarł przed 4 czerwca 1624 r. Był ostatnim męskim potomkiem mazowieckiej linii swojego rodu. Wdowa po nim wychodziła jeszcze dwukrotnie za mąż, najpierw za Krzysztofa Kiełczewskiego h. Pomian (zm. 1628), cześnika łęczyckiego, a następnie za Samuela Konarskiego h. Ossoria (zm. 1641), wojewodę malborskiego 29 .

Po bezpotomnej śmierci Jana Garwaskiego jego majątki odziedziczyły dzieci siostry Katarzyny, żony Piotra Okunia z Grodziska h. Belina, oraz siostra Dorota, która wyszła za nieznanego $z$ imienia przedstawiciela rodu Bykowskich h. Gryf (zapewne jednego $z$ synów wojewody sieradzkiego Stanisława Jana lub też kasztelana konarskiego sieradzkiego Piotra). W rzetelnym na ogół opracowaniu pióra Gustawa i Jana Zielińskich podano, że już w 1624 r. spadkobiercy kasztelanica płockiego sprzedali wszystkie pozostałe po nim dobra kasztelanowi płockiemu Walentemu Zielińskiemu. Wydaje się to jednak mało prawdopodobne. Po pierwsze dlatego, że przynajmniej na części pozostałych po nim posiadłości zabezpieczony był posag wdowy - Izabeli $z$ Karnkowskich, której pretensje

29 Por. B oniecki, Herbarz, t. V, s. 378; P.B. Ga siorowski, op. cit., s. 188; G. Z i elín s ki, J. Z i elińs ki, op. cit., cz. 2, s. 51-52, 301-311; E. O p a liński, op. cit., s. 165 (warto w tym miejscu zwrócić jednak uwage na to, że wspomnianego tu kasztelanica płockiego Jana Garwaskiego w indeksie na s. 364 błędnie utożsamiono $z$ jego bratem stryjecznym - Janem Garwaskim, kustoszem łowickim); Urzędnicy województw łęczyckiego i sieradzkiego XVI-XVIII wieku. Spisy [dalej: Urzędnicy łęczyccy], oprac. E. Opaliński i H. Żerek-Kleszcz, red. A. Gąsiorowski, Kórnik 1993, s. 57, 261; W. D w o r z a c z e k, Konarski Samuel, [w:] PSB, t. XIII, s. 470; A. P r zy b o ś, Karnkowski Jan Stanisław, s. 76 (tu błędne imię pierwszego męża Izabeli Karnkowskiej - Krzysztof zamiast Jan). 
należało zaspokoić w pierwszej kolejności. Po drugie dlatego, że Zielińscy na potwierdzenie swoich wywodów przywołuja akt oblatowany w grodzie ciechanowskim 12 lipca 1624 r. przez Piotra Okunia. Nie jest to jednak bynajmniej akt rezygnacji $z$ dóbr pozostałych po Janie Garwaskim na rzecz kasztelana płockiego, ale potwierdzenie przez Okunia, działającego w imieniu swoich nieletnich dzieci: Adama, Krzysztofa, Stanisława, Ewy, Anny i Zofii, jako spadkobierców nieżyjącej już matki - Katarzyny $z$ Garwaskich, dokonanej w sierpniu 1620 r. sprzedaży dóbr skępskich. Sądzić więc wypada, że bliższa prawdy jest informacja zawarta w herbarzu Adama Bonieckiego, w którym podano, że dobra po Janie Garwaskim nabył Walenty Zieliński od Doroty Bykowskiej (i sukcesorów Katarzyny Okuniowej) w roku 1635. Jak można przypuszczać, do tego czasu nastapiły ostateczne rozliczenia między Bykowskimi i Okuniami $z$ jednej, a Izabela Karnkowska $z$ drugiej strony. Nie istniały więc żadne przeszkody prawne, aby Walenty Zieliński wszedł w posiadanie dóbr Garwarz, Miszewo, Małoszewo i Krawięczyn oraz wójtostwa w Bodzanowie. Najpóźniej w 1635 r. wszystkie majątki należące niegdyś do mazowieckiej linii rodu Garwaskich (bez sprzedanego wcześniej Brochocina oraz Przeciszewa) przeszły w posiadanie Zielińskich h. Świnka ${ }^{30}$.

Po wygaśnięciu Garwaskich $z$ linii płockiej jedynymi kontynuatorami tradycji tego rodu byli przedstawiciele gałęzi dziedziczacej na Kutnie. Jej protoplastą, jak wspomniano, był Jerzy Garwaski (zm. 1615/1616) czwarty, najmłodszy syn Pawła, kasztelana sierpskiego, i Elżbiety Kucieńskiej, brat Stanisława i Pawła, kasztelanów płockich. Urodzony około 1555/1556 r., w przeciwieństwie do obu braci, nie wykazywał większej aktywności na scenie politycznej. Podczas elekcji 1587 r. opowiedział się jednak za Zygmuntem III, który 19 stycznia 1588 r. wynagrodził go nominacja na urząd cześnika gostynińskiego, wakujacy po awansie Pawła Czernieckiego na chorastwo gostynińskie. W następnych latach Garwaski skoncentrował się głównie na działalności gospodarczej

30 Por. Boniecki, Herbarz, t. V, s. 378; G. Zieliński, J. Zieliński, op. cit., cz. 2, s. 51, 311-314; E. O paliński, op. cit., s. 165; R. Le szczyńs ki, Okuń Krzysztof, [w:] PSB, t. XXIII, Wrocław 1978, s. 717; J. Łe m p i cki, op. cit., t. I-II, s. 49 (tu informacja, że po śmierci Jana Garwaskiego Miszewo Garwaskie przeszło w posiadanie wdowy po nim Izabeli z Karnkowskich oraz jej trzeciego męża Samuela Konarskiego. Dopiero w 1667 r. syn tej pary - ksiądz Adam Konarski - sprzedać miał tę wioskę Ludwikowi Zielińskiemu, synowi kasztelana płockiego Walentego). 
i pomnażaniu własnego majątku. W wyniku podziału dóbr po rodzicach obją dział obejmujący dobra macierzyste, więc część Kutna z przyległościami. Niestety, nie znamy składu klucza kutnowskiego w 1560 r. Nie wiemy także, które wioski, należące wcześniej do Kucieńskich, przeszły w posiadanie Garwaskich. Wiemy natomiast, że w poczatkach XVI stulecia Kucieńscy z linii dziedziczacej na Kutnie byli właścicielami wsi Sieciechów, Raszewo, Gnojenko, Solec, Wrząca, Meszne i Łężek w powiecie gostynińskim oraz Podczachy Małe, Rusinki, Sławęcin, Besk i Golbice w powiecie łęczyckim. W 1510 r. z działu tego ubyły Sławęcin, Besk i Golbice sprzedane za 500 grzywien przez kasztelana gostynińskiego Andrzeja Kucieńskiego Mikołajowi z Drzewców Drzewieckiemu. W 1519 r. tenże Kucieński, wówczas już wojewoda rawski, odbudował jednak z nawiazka wcześniejszy stan posiadania, nabywając za 1200 grzywien dobra Łanięta $z$ przyległościami (w powiecie gostynińskim) od Stanisława $z$ Mirowa Myszkowskiego ${ }^{31}$. Wydaje się jednak, że nie wszystkie wioski posiadane przez wojewodę rawskiego w 1519 r. pozostały w rękach Kucieńskich aż do roku 1560. Uwaga ta w pierwszym rzędzie dotyczy wsi Solec, Wrząca, Meszne i Łężek, w których nie odnotowano później własności spadkobierców wygasłej linii tego rodu. Warto jednak zaznaczyć, że w chwili śmierci ostatniego $\mathrm{z}$ wnuków wojewody rawskiego Andrzeja Kucieńskiego - Jerzego, kasztelana sierpskiego - w skład majątku rodowego wchodziło kilka innych, niewymienionych tu osad ${ }^{32}$.

Aby przedstawić stan dóbr kutnowskich w chwili objęcia ich przez spadkobierców młodszej linii rodu Kucieńskich, musimy poświęcić nieco uwagi młodszym siostrom kasztelanowej sierpskiej Elżbiety z Kutna Garwaskiej, czyli ciotkom jej synów: Jana, Stanisława, Pawła i Jerzego. Starsza $z$ nich - Jadwiga Kucieńska (zm. p. 1578) - około 1552 r. wyszła za mąż za późniejszego kasztelana kamieńskiego Andrzeja Gosławskiego h. Nałęcz (zm. 1580). Miała

31 Por. AGAD, MK nr 134, k. 42v; B o n i e cki, Herbarz, t. V, s. 379; T. N ow a k, op. cit., s. 142-144.

32 Wnioskując na podstawie późniejszego stanu posiadania spadkobierców młodszej linii rodu Kucieńskich oraz rejestrów poborowych województwa rawskiego $\mathrm{z}$ roku 1579 i województwa łęczyckiego z 1576 r., możemy założyć, że w skład dóbr kutnowskich w 1560 r. wchodziły miasto Kutno oraz wsie Raszewo, Gnojenko, Gołębiewek, Ryków, Łanięta, Lipie i Suchodębie oraz części Sieciechowa, Jukowa i Pomarzan w powiecie gostynińskim, jak również wsie Rusinki, Podczachy Małe i część wsi Sklęczki w województwie łęczyckim - razem 1 miasto, 9 wsi całych i 4 części wsi. 
z nim dwóch synów - Stanisława i Jana. $Z$ majątku rodowego przypadł jej dział obejmujący połowę miasta Kutna, części wsi Gołębiewek, Ryków i Sieciechów w ziemi gostynińskiej oraz części wsi Sklęczki i Podczachy Małe (druga część tej wsi należała do męża Jadwigi - Andrzeja Gosławskiego) w województwie łęczyckim. Po śmierci obojga rodziców dobra te przeszły w ręce Stanisława i Jana Gosławskich. Pierwszy z nich, ożeniony z Barbara Grodziecką h. Dryja, córka Piotra, zmarł bezpotomnie przed 1609 r. Drugi z braci Jan - ożenił się z Zofią Zakrzewską h. Ogończyk, córką Jerzego Zbożego, kasztelana kruszwickiego, i miał $z$ nią dwóch synów Łukasza i Jana. Gosławscy stopniowo wyzbywali się swoich udziałów w dobrach kutnowskich. Swoją połowę Kutna (z wyłączeniem niewielkiej części miasta, którą Stanisław Gosławski trzymał do śmierci) sprzedali podkomorzemu gostynińskiemu Stanisławowi Kucieńskiemu $z$ linii na Łakoszynie. Zrezygnowali też - na rzecz różnych nabywców - ze swoich udziałów w należących do klucza kutnowskiego wioskach. Kiedy w 1602 r. Łukasz i Jan Gosławscy dokonywali podziału dóbr po ojcu, nie posiadali już żadnej osiadłości w dobrach należacych niegdyś do młodszej linii rodu Kucieńskich. Najmłodsza siostra Elżbiety Garwaskiej - Urszula - między 1561 a 1566 r. poślubiła Mikołaja Przerembskiego h. Nowina (zm. 1575), dworzanina królewskiego i stolnika sieradzkiego, rodzonego brata arcybiskupa gnieźnieńskiego Jana. Miała $z$ nim syna Jana, męża wojewodzianki płockiej Zofii Zielińskiej, młodszej siostry Doroty, żony kasztelana płockiego Pawła Garwaskiego. W dziale dóbr po rodzicach Urszula $z$ Kutna Przerembska wzięła Łanięta, Lipie i część Suchodębia w parafii Łanięta oraz części wsi Juków i Pomarzany w parafii Sokołów. W rejestrze poborowym województwa rawskiego $z 1579 \mathrm{r}$. odnotowano tu odpowiednio: 19, 2, 18,5, 1,5 i 3 łany kmiece (razem 44 łany). Były to majętności na tyle zamożne i rozległe, że Przerembska nie otrzymała już żadnego udziału w mieście Kutnie. Zmarła w drugiej połowie $1587 \mathrm{r}$. Dnia 4 stycznia 1588 r. Zygmunt III nadał bowiem Janowi i Zofii z Zielińskich Przerembskim w dożywotnie posiadanie wsie Konary, Rudniki i Zawada w województwie sieradzkim, które wróciły do jego dyspozycji po śmierci Urszuli z Kutna, wdowy po Mikołaju Przerembskim, stolniku sieradzkim ${ }^{33}$.

33 Por. T. N ow a k, op. cit., s. 145-147; AGAD, ŁGI, ks. 71, k. 518v-519v; ks. 95, k. 15; BKPAN, TD, Grodzkie i ziemskie, Kalisz, Rezygnacje XVI wiek, 680 (Nr. 5), 1578, f. 10; Grodzkie i ziemskie, Konin, 3658 (Nr. 6 gr. I. i Rel. Kon. 6), 1553, 
Z dużą doza prawdopodobieństwa możemy zatem powiedzieć, że na dział dzieci kasztelana sierpskiego Pawła Garwaskiego i wojewodzianki rawskiej Elżbiety Kucieńskiej przypadła połowa miasta Kutna, wsie Raszewo i Gnojenko, części wsi Gołębiewek, Ryków i Suchodębie w ziemi gostynińskiej oraz wieś Rusinki w województwie łęczyckim - razem pół miasta, 3 wsie całe i 3 części wsi. Nie znamy niestety areału ziemi uprawnej w tych dobrach, ale możemy przypuszczać, że łączna liczba łanów kmiecych była tu znacznie mniejsza niż w majętnościach, które przypadły w dziale starszym braciom Jerzego Garwaskiego. Na sytuacje materialna tego ostatniego w korzystny sposób oddziaływało jednak to, że w skład odziedziczonych przez niego posiadłości wchodziła połowa Kutna. Czerpiąc znaczne korzyści $z$ osiadłości $\mathrm{w}$ mieście, mógł on więc liczyć na dochody $z$ dóbr porównywalne $z$ dochodami jego braci. Nie wydaje się jednak, aby Jerzy Garwaski objął od razu cały spadek po matce. Prawa do dóbr macierzystych miały bowiem również jego siostry: Jadwiga i Anna (w częściach równych działom przypadającym każdemu $z$ braci), które musiały zostać spłacone. Być może $z$ tego powodu część wiosek klucza kutnowskiego została przez Garwaskich sprzedana lub też zastawiona. Możemy również założyć, że przynajmniej do roku 1583, a więc do śmierci stryja Hieronima, który trzymał część dóbr rodowych w województwie płockim (Wola Młocka), Stanisław i Paweł Garwascy użytkowali jakieś (przypuszczalnie niewielkie) części klucza kutnowskiego. $Z$ biegiem czasu niemal wszystkie wsie przejęte przez Garwaskich w spadku po Kucieńskich (za wyjątkiem Suchodębia) znalazły się jednak w rękach Jerzego, który konsekwentnie dążył do przejęcia wszystkich dóbr macierzystych i powiększenia swoich posiadłości $\mathrm{w}$ ziemi gostynińskiej oraz $\mathrm{w}$ województwie łęczyckim. $Z$ pewnością $\mathrm{w}$ realizacji tego celu pomogło mu korzystne małżeństwo. Około 1580 r. poślubił on bowiem Agnieszkę Szczawińską h. Prawdzic, córkę Stanisława Szczawińskiego (Szubskiego) i Jadwigi Trębskiej h. Prawdzic. Szczawińscy byli zamożna i dobrze skoligaconą rodziną senatorską. Co prawda teść Jerzego Garwaskiego nie piastował żadnych urzędów, ale jego brat Szymon (zm. 1590) był kasztela-

f. 150; 2193 (Nr. 6 zs. I. i Rel. Z. Kon. 6), 1560, f. 223v; 4599 (Nr. 21 I. i Rel. Kon. 21) 1584, f. 266; 5729 (Nr. 30 I. i Rez. Kon. 30), 1602, f. 319; Źródła dziejowe, t. XIII (Polska XVI wieku pod względem geograficzno-statystycznym, Wielkopolska, t. II), wyd. A. Pawiński, Warszawa 1883, s. 84; Źródła dziejowe, t. XVI, s. 195; H. K o w a $1 \mathrm{~s} \mathrm{k} \mathrm{a,} \mathrm{Przerębski} \mathrm{(Przerembski)} \mathrm{Jan,} \mathrm{[w:]} \mathrm{PSB,} \mathrm{t.} \mathrm{XXVIII,} \mathrm{Wrocław} \mathrm{1984-}$ 1985, s. 756; Urzędnicy łęczyccy, nr 1274, s. 173; AGAD, MK nr 134, k. 5-5v. 
nem inowłodzkim, a dalszy kuzyn Paweł (zm. 1594/1595) kasztelanem łęczyckim. Braćmi Agnieszki Garwaskiej byli Piotr (zm. 1598) oraz Mikołaj (ok. 1548-1620), najpierw kasztelan brzeziński, a następnie (od 1612 r.) łęczycki. Obaj szwagrowie Jerzego Garwaskiego zmarli bezpotomnie. Otworzyło to jego dzieciom perspektywy na przejęcie części majątku po kasztelanie łęczyckim³ ${ }^{34}$

${ }^{34} \mathrm{Na}$ podstawie rejestrów poborowych województwa rawskiego z 1579 r. i łęczyckiego z roku 1576 możemy stwierdzić jedynie, że na przedmieściach Kutna Garwascy mieli 6 łanów (5 łanów należało do Gosławskich), w będącej ich własnością części Suchodębia odnotowano 8 łanów, a wsie Gołębiewek i Ryków (należące w części do Garwaskich, w części do Gosławskich) liczyły odpowiednio 4 i 3 łany. W przywołanych tu rejestrach nie podano natomiast liczby łanów we wsi Gnojenko, a wsie Raszewo i Rusinki w ogóle nie zostały odnotowane. Dodajmy także, że w 1579 r. z miasta Kutna wybrano następujące podatki: 12 florenów 24 grosze szosu, 28 florenów 15 groszy od rzemieślników, 9 florenów od kotłów gorzałczanych, 110 florenów 12 groszy czopowego oraz 21 florenów od zamieszkujących tu Żydów. Por. Źródła dziejowe, t. XVI, s. 194, 195, 211; SGKP, t. XV, cz. 2, s. 204. W województwie łęczyckim jako własność Garwaskich odnotowano jedynie część wsi Krzeszynko (Krzesin), która została zamieniona na folwark i w zwiazku $z$ tym nie wniesiono $z$ niej poboru. Por. Źródła dziejowe, t. XIII, s. 84. Dodajmy także, że dobra należące do kasztelana łęczyckiego Mikołaja Szczawińskiego zostały znacznie uszczuplone w wyniku tego, że w $1604 \mathrm{r}$. ufundował on $z$ krewnymi klasztor norbertanek pw. Wniebowzięcia NMP w Łęczycy. Klasztorowi temu zapisał wszystkie swoje dobra w województwie łęczyckim, czyli wsie Szubsk Duży i Mały, Mikołajki, Wójciki i Grzymkowska Wolę. Dla swoich krewnych przeznaczył natomiast najpewniej dobra w województwie rawskim, więc Szczawin Borowy, Zabłocie i Gnojno. Spadkiem po kasztelanie łęczyckim Garwascy musieli się jednak podzielić ze spadkobiercami sióstr swojej matki - Jadwigi, zamężnej najpierw za nieznanym $z$ imienia Borzewskim, a następnie żony Piotra Lasockiego, cześnika dobrzyńskiego, oraz Anny, żony Erazma Zieleńskiego. Por. D. K a r c z e w s k i, T. N ow a k, Szczawiński (Szubski) Mikołaj, [w:] PSB, t. XLVII, Warszawa-Kraków 2010, s. 202-203; Urzędnicy kujawscy i dobrzyńscy XVI-XVIII wieku. Spisy [dalej: Urzędnicy kujawscy], oprac. K. Mikulski, W. Stanek, przy współudziale Z. Górskiego i R. Kabacińskiego, red. A. Gąsiorowski, Kórnik 1999, s. 170 (dotyczy Piotra Lasockiego). Autorzy biogramu Mikołaja Szczawińskiego stwierdzają, że przed rokiem 1577 ożenił się on z Agnieszką (ur. 15 I 1553), córka podkomorzego dobrzyńskiego Jana Lasockiego $z$ Glewa h. Dołęga, a według Adama Bonieckiego, córką Stanisława (1512-1564) i Anny Radzimińskiej. Por. D. Ka rczewski, T. N ow a k, op. cit., s. 202. W rzeczywistości kasztelan łęczycki miał zapewne dwie żony pochodzace $z$ domu Lasockich h. Dołęga: pierwsza pochodzacca $z$ linii na Glewie i druga, córkę Stanisława. W 1585 r. Stanisław Gosławski (współdziedzic Kutna) skwitował bowiem Annę de Glewo, żonę Mikołaja Szczawińskiego z 600 złotych na poczet 4000 złotych długu. W 1588 r. tenże Gosławski wystapił natomiast na drogę sądową przeciwko Agnieszce Lasockiej, córce nieżyjącego już Stanisława, a żonie Mikołaja Szubskiego sive Szczawińskiego. Por. BKPAN, TD, 
Z małżeństwa $z$ Agnieszką Szczawińską, zmarłą około 1600 r., miał Jerzy Garwaski dwie córki - Katarzynę i Dorotę - oraz czterech synów: Stanisława, Pawła, Piotra i Mikołaja. W maju 1602 r. druga żoną Jerzego Garwaskiego była już Anna $z$ Nieborowa Tarnowska h. Rola, córka Mikołaja, kasztelana sochaczewskiego, i kniaziówny Małgorzaty ze Zbaraża Woronieckiej h. Korybut. Żonie tej oprawił posag i wiano na pozyskanych w 1597 r. od Jakuba Tylickiego (być może wykupionych $z$ zastawu lub też odkupionych po wcześniejszej sprzedaży) wsiach Gnojenko z młynem zwanym Borowy i Raszewo w ziemi gostynińskiej oraz Podczachy Małe (Podczaski) w województwie łęczyckim. W 1606 r. Anna z Tarnowskich Garwaska, po odebraniu ostatniej raty posagu, skwitowała brata Jana (ojciec już nie żył) $z$ wszelkich pretensji do dóbr ojczystych i macierzystych. W roku 1608 kasztelanic sochaczewski Jan Tarnowski (brat Anny) zastawił $z$ kolei Jerzemu Garwaskiemu wieś Piaski w ziemi sochaczewskiej. $Z$ małżeństwa $z$ Anną Tarnowska miał Garwaski dwóch synów: Jana i Zygmunta oraz cztery córki: Małgorzatę, Helenę, Agnieszkę i Urszulę. W 1610 r. Jerzy Garwaski objął urząd starosty gostynińskiego scedowany mu przez starszego brata Stanisława. Warto przy tej okazji wspomnieć, że w czasie, kiedy zarządzał tą królewszczyzna, na zamku w Gostyninie więziony był były władca Moskwy Wasyl IV Szujski z najbliższa rodzina. Głośnym echem w całej Rzeczypospolitej odbiły się też niespodziewane zgony cara (zm. 12/22 września 1612 r.) oraz jego brata Dymitra (zm. 17/27 września) i bratowej Katarzyny (zm. 15/25 września), córki sławnego i osławionego Maluty Skuratowa. Nagła śmierć trójki członków rodziny carskiej wywołała lawinę plotek i domysłów. O otrucie Szujskich pomawiano polskich regalistów oraz przebywających w Gostyninie Rosjan. Sprawa ta nigdy nie została wyjaśniona. Nie wydaje się jednak, by wydarzenia te nadszarpnęły reputacje Jerzego Garwaskiego. Nadal niezbyt czynny na scenie politycznej, wykazywał on ogromna zapobiegliwość w gromadzeniu dóbr ziemskich. W bliżej nieokreślonym czasie przejął od obu braci należące do nich części klucza kutnowskiego. W 1613 r. otrzymał spłatę za połowę dóbr ziemskich kasztelana płockiego Stanisława (być może jakąś formą wzajemnych rozliczeń między Garwaskimi była dokonana na rzecz Jerzego cesja starostwa gostynińskiego). Nie wiemy niestety, pomijając transakcję

Grodzkie i ziemskie, Konin, 4689 (Nr. 21 I. i Rel. Kon. 21), 1585, f. 516v; 4801 (Nr. 23 I. i Rel. Kon. 23), 1588, f. 158. 
z Tylickim z 1597 r., w jaki sposób i kiedy Garwaski pozyskiwał kolejne posiadłości. Możemy natomiast stwierdzić, że u schyłku swego życia starosta gostyniński był właścicielem połowy miasta Kutna, wsi Gołębiewek, Ryków, Gnojenko z młynem zwanym Borowy, Raszewo i Ruszków, części wsi Dudki i połowy borów soleckich w ziemi gostynińskiej oraz wsi Rusinki (Rusinówek), Podczachy Wielkie, Podczachy Małe (Podczaski), Ocice Wielkie i Ocice Małe w województwie i powiecie łęczyckim. Trzymał też w zastawie wieś Piaski w ziemi sochaczewskiej. Jego majątek składał się więc z połowy miasta, 10 wsi całych, 1 części wsi i 1 wioski, gdzie był posesorem zastawnym oraz zamku, miasta i 5 wsi królewskich. Była to $z$ pewnościa jedna $z$ większych fortun szlacheckich $w$ województwach łęczyckim i rawskim. Nie znamy niestety dokładnej daty śmierci Jerzego Garwaskiego. Możemy jednak przypuszczać, że zmarł pod koniec 1615 lub też na początku 1616 r. ${ }^{35}$

35 Informacje o dzieciach i majątku Jerzego Garwaskiego na podstawie wpisów do ksiąg grodzkich łęczyckich. Szczegóły poniżej, w kolejnych przypisach. Por. też AGAD, ŁGI 119, k. 223-224v; 133, k. 445v; BKPAN, Grodzkie i ziemskie, Pyzdry, część 1, 1408, (Nr. 128), 1597, f. 144; Wywody kanoników płockich, kanonik Jan Garwaski, poz. 6, 1622, sygn. 9, k. 365. Dodajmy także, że matka Anny z Tarnowskich Garwaskiej była córką kniazia Michała Woronieckiego i słynnej Barbary Giżanki, kochanki Zygmunta II Augusta, a wnuczką kniazia Jerzego Woronieckiego i Katarzyny Uchańskiej h. Radwan. Por. N. J a k o w e n k o, Ukrainska szlachta $z$ kinca XIV - do seredyny XVII stolitja. Wołyń $i$ centralna Ukraina, wyd. 2, Kyjw 2008, s. 339; Z. W d ow i s z e w s k i, Giza (Giżanka, Gissa) Barbara, [w:] PSB, t. VIII, s. 15-16. Por. też B o n i e c k i, Herbarz, t. V, s. 379; SGKP, t. II, Warszawa, s. 749; A. Andrusiewi cz, Krwawa dekada. Polska interwencja $w$ Rosji 1602-1612. Dyplomacja, samozwańcy, wojna, 2013, s. 436, 515; M. C h u dzyński, Car Wasyl Szujski na zamku $w$ Gostyninie (1611-1612), „Notatki Płockie” 2012, nr 1/230, s. 3-13 (tekst pełen nieścisłości i fatalny pod względem warsztatowym); E. O p a liń s ki, op. cit., s. 291 (tu stwierdzenie, że Jerzy Garwaski zmarł około 1615 r.), 306 (tu informacja, że nie żył na pewno w 1617 r.). Informacje dr H. Żerek-Kleszcz na podstawie: AGAD, ŁGI, ks. 111, k. 222v; ks. 115, k. 186v-188v; Łęczyckie ziemskie, ks. 64, k. 922. Warto w tym miejscu przytoczyć kompletnie chybiony i absurdalny wręcz wywód przodków Jerzego Garwaskiego ułożony przez M.J. Minakowskiego, który opierając się na wzmiance zawartej w herbarzu A. Bonieckiego, że Ewa Kucieńska, córka Jerzego i Elżbiety $z$ Krasińskich, była żona nieznanego $z$ imienia Garwaskiego, oraz ustaleniach A. Pszczółkowskiego (syn Jerzego, kanonik płocki Jan Garwaski, wskazał jako babkę ojczystą Elżbietę Kucieńska), doszedł do zdumiewającego wprost wniosku, że starosta gostyniński Jerzy Garwaski (ur. około 1560 - wszystkie daty życia wymienionych tu osób zostały zaczerpnięte $z$ cytowanego wywodu przodków) był synem nieznanego $z$ imienia Garwaskiego i Ewy Elżbiety Kucieńskiej (ur. około 1530), wnukiem Jerzego Kucieńskiego (ur. około 1570) i Elżbiety Krasińskiej oraz 
W roku 1616 Anna $z$ Tarnowskich Garwaska, wdowa po Jerzym, ustapiła bowiem $z$ dożywocia na dobrach Raszewo, Gnojenko $z$ młynem Borowy i Podczachy Małe (Podczaski) na rzecz pasierbów: Stanisława, dziekana płockiego i kustosza łowickiego, jezuity Mikołaja, Pawła i Piotra oraz własnych, małoletnich jeszcze synów Jana i Zygmunta. Wspomniano wówczas również o córkach Anny Tarnowskiej: Małgorzacie, Helenie, Agnieszce i Urszuli. Wśród dzieci Jerzego Garwaskiego nie wymieniono natomiast córek $z$ pierwszego małżeństwa - Katarzyny i Doroty. Jest to o tyle zrozumiałe, że obie zostały wcześniej wyposażone przez ojca i zrzekły się wszystkich pretensji do dóbr. Katarzyna Garwaska, prawdopodobnie najstarsza $z$ rodzeństwa, urodzona zapewne około 1582 r., krótko przed rokiem 1600 poślubiła Marcjana Szamowskiego h. Prus I (zm. 1612), syna Jana, kasztelana brzezińskiego, i Anny z Bogusławic Sierakowskiej h. Ogończyk, wojewodzianki łęczyckiej. Miała z nim synów Stanisława i Jana, późniejszego kasztelana gostynińskiego. Po raz drugi, w roku 1613, wyszła za mąż za Piotra Sasin Karśnickiego h. Jastrzębiec, syna Jana (zm. 1593), podkomorzego łęczyckiego, a brata Jakuba (zm. 1619), kasztelana inowłodzkiego. W 1617 r., po śmierci teściowej, kasztelanowej brzezińskiej Anny z Bogusławic Szamowskiej, będąc już żoną Piotra Sasin Karśnickiego, uzyskała od sióstr i brata pierwszego męża zrzeczenie się ich praw do części wsi Strzegocin w województwie łęczyckim. Zmarła przed rokiem 1623, kiedy jej synowie - Stanisław i Jan Szamowscy - działajacc w towarzystwie wuja, Piotra Garwaskiego dokonali rozliczenia spadku po matce $z$ ojczymem, Piotrem Sasin Karśnickim. Być może wówczas młodzi Szamowscy przejęli w posesję wieś Gnojno w ziemi gostynińskiej (wchodząca niegdyś w skład dóbr oprawnych Agnieszki z Lasockich, żony zmarłego w 1620 r. kasztelana łęczyckiego Mikołaja Szczawińskiego - rodzonego wuja Katarzyny Garwaskiej). Jeśli nawet tak było (równie dobrze Szamowscy mogli odziedziczyć tę wieś po ojcu), to nie zatrzymali Gnojna zbyt

prawnukiem Stanisława Kucieńskiego (ur. około 1550 r.) i Stanisława Krasińskiego (1558-1617). Dla uzmysłowienia sobie całej absurdalności przytoczonego tu wywodu zwróćmy jedynie uwagę na to, że dziadek macierzysty Jerzego Garwaskiego byłby o 10 lat młodszy od swojego wnuka (i 40 lat młodszy od własnej córki), a przywołani tu domniemani pradziadkowie probanta śmiało mogliby zostać uznani za jego rówieśników. Por. Jerzy Garwaski z Garwarza h. Grzymała (odm.) (ID: 5.959.26), [w:] WGM, dostęp: 23 X 2015 r. W uzupełnieniu dodajmy tylko, że uznana za matkę Jerzego Garwaskiego Ewa (nie Ewa Elżbieta) Kucieńska była w rzeczywistości żona jego najmłodszego syna Zygmunta. 
długo w swoich rękach, gdyż jeszcze w tym samym roku odprzedali tę posiadłość wspomnianemu wujowi, Piotrowi Garwaskiemu. Rodzona siostra Katarzyny - Dorota Garwaska - została norbertanka w Łęczycy. W 1611 r., po otrzymaniu posagu i wyprawy, skwitowała ona ojca $z$ wszelkich pretensji do dóbr ojczystych i macierzystych $^{36}$.

W dniu 13 lipca 1623 r. przeprowadzono w Kutnie podział dóbr po staroście gostynińskim Jerzym Garwaskim. W spisanym wówczas akcie wymieniono wszystkie jego dzieci $z$ wyjatkiem wyposażonych już córek $z$ pierwszego małżeństwa: Katarzyny $1{ }^{\circ} \mathrm{v}$. Szamowskiej, 2。 v. Sasin Karśnickiej i Doroty, norbertanki łęczyckiej. Zwraca uwage to, że ewentualny podział majątku między sześciu synów Jerzego mógł doprowadzić do poważnego obniżenia statusu majątkowego każdego $z$ nich i głębokiego kryzysu rodziny. Żeby tego uniknąć, dwaj synowie starosty gostynińskiego $z$ jego związku z Agnieszką Szczawińska, którzy wybrali karierę kościelną, zrzekli się udziału w spadku na rzecz swoich rodzonych braci - jezuita Mikołaj na rzecz Pawła, a dziekan płocki Stanisław na rzecz Piotra. Wszystkie dobra ziemskie po Jerzym Garwaskim zostały więc podzielone na trzy działy, $z$ których pierwszy objął Paweł, drugi Piotr, a trzeci przypadł do wspólnego użytkowania kustoszowi łowickiemu Janowi oraz najmłodszemu $z$ braci, nieletniemu jeszcze Zygmuntowi. Pawłowi Garwaskiemu dostała się połowa miasta Kutna, część wsi Dudki oraz bór w Gołebiewku. Piotr objął wsie Gołębiewko i Ryków w ziemi gostynińskiej oraz Ocice Wielkie i Ocice Małe w województwie łęczyckim. Jemu przypadła także połowa borów soleckich (druga połowa należała do Andrzeja Soleckiego) $z$ tym jednak zastrzeżeniem, że wolny wrąb w tych lasach mieli mieć również Paweł oraz dwaj najmłodsi bracia. Ze względu na różnice w wartości dwóch pierwszych działów Paweł Garwaski dopłacić miał Piotrowi 2000 złotych. Na schedę kustosza łowickiego Jana oraz Zygmunta składały się natomiast wsie Gnojenko $z$ młynem Borowy i folwarkiem, Ruszków z młynem i Raszewo w ziemi gostynińskiej oraz Podczachy Wielkie, Podczachy Małe (Podczaski) i Rusinki (Rusinówek) w województwie łęczyckim. Na wszystkich braci nałożono obowiązek solidarnego spłacania długów ojcowskich, w tym zwłaszcza 500 złotych ciążących na Ruszkowie. Każdy z nich

36 Por. AGAD, ŁGI, ks. 146, k. 124v; informacje dr H. Żerek-Kleszcz na podstawie: AGAD, ŁGI, ks. 122, k. 398-398v; ks. 131, k. 512-513; Łęczyckie grodzkie, relacje, ks. 61, k. 658; Urzędnicy łęczyccy, nr 132, s. 39 i nr 476, s. 80. 
(w przypadku młodszych starościców gostynińskich obowiązek ten nałożono na Jana) miał również się zaopiekować jedną niezamężna siostrą: Paweł Helena, Piotr Małgorzatą, a kustosz łowicki Urszulą. Do czasu zamaż́pójścia wszystkie panny miały mieć zapewnione stosowne utrzymanie. Młodzi Garwascy przyjęli też na siebie zobowiąanie, że każda $z$ sióstr otrzyma w przyszłości posag w wysokości 5000 złotych. $Z$ tego postanowienia wyłączona została jednak czwarta córka Jerzego Garwaskiego i Anny Tarnowskiej - Agnieszka, która wcześniej wstąpiła do klasztoru i po odebraniu posagu i wiana skwitowała braci $z$ pretensji do dóbr. O dalszych losach wspomnianych tu córek Jerzego Garwaskiego nie mamy niestety żadnych wiadomości. Zawarta w Kutnie umowa podziałowa została zabezpieczona wadium w wysokości 10000 złotych. W osobnym akcie zagwarantowano zaś wdowie po staroście gostynińskim Annie z Tarnowa Garwaskiej dożywocie na wsiach Raszewo i Gnojenko, wydzielonych ze schedy, która przypadła jej rodzonym synom ${ }^{37}$. Zwraca uwage to, że w akcie podziałowym nie wspomniano o zastawie na Piaskach, która to wieś prawdopodobnie została wcześniej wykupiona od Garwaskich przez Jana Tarnowskiego.

Anna z Tarnowa Garwaska żyła jeszcze w 1634 r. Ustapiła bowiem wtedy $z$ dożywocia zapisanego jej na dobrach Podczachy Wielkie, Podczachy Małe i Ruszków przez nieżyjącego już starszego syna, kustosza łowickiego i kanonika płockiego Jana. Ponadto skwitowała $z$ pewnej sumy pasierbów: Stanisława, dziekana płockiego i kanonika krakowskiego, Pawła i Piotra oraz własnego syna Zygmunta ${ }^{38}$. W akcie tym nie występuje czwarty $z$ pasierbów Anny - jezuita Mikołaj, który prawdopodobnie również w tym czasie już nie żył.

Stanisław Garwaski (zm. 1635) był najpewniej najstarszym synem Jerzego, starosty gostynińskiego, i Agnieszki ze Szczawińskich. Urodził się zapewne około 1585 r. Z pewnością odbył jakieś studia zagraniczne. Nie studiował jednak na najczęściej odwiedzanych przez Polaków uniwersytetach włoskich, czyli w Padwie, Bolonii czy też w Rzymie. Przeznaczony do kariery kościelnej, dość szybko zaczął pozyskiwać kolejne dostojeństwa. W chwili śmierci ojca był już dziekanem płockim i kustoszem łowickim. Kilka lat później został kanonikiem krakowskim. Być może $z$ jego wejściem do kapituły krakowskiej należy łączyć ustapienie $z$ kustodii łowic-

37 Por. AGAD, ŁGI, ks. 146, k. 331-334v.

38 Informacja dr H. Żerek-Kleszcz na podstawie: AGAD, ŁGI, ks. 165, k. 2v-3. 
kiej na rzecz przyrodniego brata Jana w roku 1618. Garwaskiego tytułowano także sekretarzem królewskim. Pokrewieństwo z kasztelanem płockim Stanisławem Garwaskim, którego był bratankiem, ułatwiło mu dostęp do najwyższych dygnitarzy polskiego Kościoła zaprzyjaźnionych $z$ jego stryjem: prymasów Stanisława Karnkowskiego, Jana Tarnowskiego, Wojciecha Baranowskiego i Wawrzyńca Gembickiego oraz biskupów krakowskich Piotra Tylickiego i Marcina Szyszkowskiego. Dobre stosunki łączace młodego prałata $z$ najważniejszymi przedstawicielami episkopatu $z$ pewnościa ułatwiały mu karierę. Umożliwiły mu też zgromadzenie sporego majątku. Ksiądz Stanisław Garwaski uważany był powszechnie za człowieka wykształconego, pobożnego i wytwornego w obejściu. Uzyskał tak dużą niezależność materialną, że mógł zrezygnować na rzecz młodszych braci $z$ przypadającej mu części dóbr po ojcu. Był też typowym prałatem epoki odrodzenia katolickiego. Zgromadzone przez siebie zasoby przeznaczał na liczne fundacje, spośród których wspomnieć można o dokonanej przez niego przebudowie w stylu barokowym kościółka św. Piotra i św. Józefa przy ulicy Grodzkiej w Krakowie, sprawieniu nowego ołtarza w kaplicy św. Tomasza i Matki Boskiej Śnieżnej w katedrze na Wawelu oraz o ustanowieniu specjalnego funduszu, aby w każda sobotę odbywały się tutaj msze śpiewane o Niepokalanym Poczęciu Najświętszej Marii Panny. Garwaski uświetniał też i na swój koszt przyozdabiał szereg innych kościołów, m.in. w Płocku, Piotrawinie (był tu proboszczem) oraz w Krakowie (jezuicki św. Piotra i Pawła). Konsekwentnie wspierał materialnie zakon jezuitów. Ustanowił ponadto specjalny fundusz na utrzymanie nadzwyczajnego kaznodziei w katedrze wawelskiej. Hojna darowizna w wysokości 10000 złotych wsparł także oratorium akademickie, zaznaczajac, aby renta $z$ tego funduszu w części była rozdzielana między kapelanów, spowiedników i ekonoma, w części zaś przeznaczana na reperację paramentów kościelnych oraz zakup wosku i wina ${ }^{39}$.

39 Por. Ni e s i e c ki, Herbarz, t. IV, s. 77; H. B a ry c z, Garwaski Stanisław, [w:] PSB, t. VII, s. 292 (z pewnymi przekłamaniami); L. Łę to w s k i, op. cit., t. II, s. 240-242; Garwaski Stanisław, [w:] Encyklopedia Krakowa, Warszawa-Kraków 2000, s. 233; E. O p a 1 iń ski, op. cit., s. 291, 364; T. G r a ff, Wokót staropolskich fundacji $i$ benefaktorów Szkół Nowodworskich w Krakowie, „Folia Historica Cracoviensia" 2013, R. XIX, s. 169, 173 (tu błędna informacja, że zapis Garwaskiego na rzecz oratorium akademickiego został dokonany w 1637 r.); K. P ełk a, Kariera braci... (z powieleniem nieścisłości zawartych w biogramie Garwaskiego autorstwa H. Barycza). 
Jego największą zasługa było jednak utworzenie wielkiej fundacji stypendialnej (borkarni) na Uniwersytecie Krakowskim, znanej pod nazwą „Bursa Garwasciana”. Z myślą o zamierzonym przedsięwzięciu nabył po 1629 r. wsie Wrząsowice (Wrzosowice) w powiecie szczyrzyckim oraz Sieradzice (Świradzice) w powiecie proszowskim, które pierwotnie chciał oddać na cele edukacyjne krakowskiemu kolegium jezuitów, ale ostatecznie zapisał Bursie Jurystów. Dochody $z$ obu wiosek miały iść na utrzymanie konwiktu, który pierwotnie dysponował 30, potem zaś 24 miejscami dla ubogiej młodzieży szlacheckiej, w pierwszym rzędzie spokrewnionej $z$ fundatorem, względnie zaś pochodzacej $z$ województwa płockiego. Pierwszeństwo $\mathrm{w}$ przyjęciu mieli mieć studenci prawa. Siedziba tego konwiktu została Bursa Jurystów przy ul. Grodzkiej. Stypendyści korzystali ze stołówki, majac do dyspozycji chleb i piwo bez ograniczeń oraz dwa duże posiłki w ciagu dnia, $z$ wyjątkiem dni postnych, kiedy przysługiwała im jedynie polewka, ryba i jarzyny. Fundacja Garwaskiego, przyjęta przez Akademię 10 października 1635 r., zapewniła jej samej oraz złączonym z nią Szkołom Nowodworskim stały dopływ młodzieży $z$ Mazowsza zdobywającej w Krakowie wykształcenie prawnicze. „Bursa Garwasciana” uzyskała zatwierdzenie konstytucja sejmowa w roku 1662. Stanisław Garwaski zmarł w Krakowie 23 grudnia 1635 r. i zostal pochowany w katedrze wawelskiej, gdzie wystawiono mu nagrobek ${ }^{40}$.

Paweł Garwaski (zm. p. 1654) był zapewne drugim synem starosty gostynińskiego Jerzego i Agnieszki ze Szczawińskich. Urodził się prawdopodobnie około 1588 r. O jego życiu i działalności zachowało się niewiele informacji. Nic nie wiadomo ani o jego młodo-

40 Por. B o n i e c ki, Herbarz, t. V, s. 379; N i e s i e c ki, Herbarz, t. IV, s. 77; L. Łe to ow ski, op. cit., t. II, s. 240; H. B a ry c z, op. cit., s. 292; i d e m, Historia Szkół Nowodworskich, t. I (Od założenia do reformy H. Kołłataja: 1588-1777), Kraków 1947, s. 144-148; F. S i a r c z y ń s k i, op. cit., cz. 1, s. 132; i d e m, Obraz wieku panowania Zygmunta III króla polskiego i szwedzkiego, czyli obraz stanu, narodu i kraju, t. I, Poznań 1843, s. 185; E. O p aliń s ki, op. cit., s. 291, 364; T. Graff, op. cit., s. 168 (tu błędne datowanie fundacji Garwaskiego dla Bursy Jurystów na lata 1635-1637), 173; K. P ełka, Kariera braci...; Vol. leg., t. IV, Petersburg 1859, s. 401 (z zatwierdzeniem fundacji Garwaskiego uchwalono, że wsi Wrząsowice i Sieradzice w województwie krakowskim zostana zwolnione od wszelkich ciężarów wojskowych); Rejestr poborowy województwa krakowskiego $z$ roku 1629, oprac. W. Domin, J. Kolasa, S. Trzyna, S. Żyga, red. S. Inglot, Kraków 1956, s. 50, 105; Rejestr poborowy województwa krakowskiego z roku 1680 wraz $z$ aneksem miast według rejestru $z$ roku 1655, oprac. E. Trzyna. S. Żyga, red. S. Inglot, Wrocław 1959, s. 62, 105. 
ści, ani też o jego wykształceniu. Wiemy natomiast, że w $1618 \mathrm{r}$. ożenił się z Anną Krasińską h. Ślepowron, córką Franciszka (zm. 1603), kasztelana ciechanowskiego, oraz zapewne jego drugiej żony, Zofii z Lubieńca Niemojewskiej h. Rola, kasztelanki chełmińskiej. Dnia 6 sierpnia 1618 r. małżonkowie spisali akt dożywocia. W tym samym dniu Paweł oprawił posag żony na części miasta Kutna. Oba akty zostały następnie roborowane w księgach grodu łęczyckiego. W 1623 r., kiedy dokonano podziału dóbr ziemskich po staroście gostynińskim, Pawłowi Garwaskiemu przypadła połowa miasta Kutna, część wsi Dudki oraz prawo wrębu w borach soleckich. W 1630 r. Piotr Tarnowski, wojszczyc gostyniński, ustanowił go jednym $z$ opiekunów swoich dzieci. Paweł Garwaski pełnił urząd podczaszego gostynińskiego, który otrzymał za panowania Władysława IV. Jesienia $1632 \mathrm{r}$. uczestniczył w elekcji tego władcy i podpisał jego wybór $z$ elektorami $z$ ziemi gostynińskiej (nie sprawował wówczas jeszcze żadnego urzędu). Autorzy herbarzy datuja śmierć Garwaskiego na rok 1636 lub 1639. Można jednak przypuszczać, że żadna $z$ tych dat nie jest prawdziwa. Nie $\dot{z} y ł$ on już jednak na pewno w 1654 r., kiedy Anna $z$ Krasnego, dziedziczka na Białej, została określona jako wdowa po Pawle Garwaskim, podczaszym gostynińskim. $Z$ małżeństwa $z$ Anną Krasińską nie pozostawił potomstwa, a należące do niego dobra ziemskie, po wykupieniu praw do dożywocia od wdowy, przeszły w posiadanie jego brata Piotra ${ }^{41}$.

Piotr Garwaski (zm. p. 1660), urodzony około 1590 r., był trzecim synem Jerzego, starosty gostynińskiego, i Agnieszki ze Szcza-

${ }^{41}$ Por. B on i e c k i, Herbarz, t. IV, s. 379; U ru s k i, Herbarz, t. IV, s. 103 (tu błędna informacja, że Paweł Garwaski miał synów Piotra i Zygmunta); AGAD, ŁGI 135, k. 363-365v; 146, k. 331v-334v; M. Kobie re cki, Dzieje Kutna i okolicznych wsi w XVII-XVIII wieku, [w:] Kutno poprzez..., t. I, s. 177, 180; W. D wo rzaczek, Genealogia, t. II (Tablice), Warszawa 1959, tabl. 136; W. K a c z orowski, P. Dydyński, Reprezentacja Mazowsza i Podlasia wśród elektorów Władysława IV w 1632 roku, „Studia z Dziejów Państwa i Prawa Polskiego” 2006, t. IX, cz. 2, s. 303; E. O palińs ki, op. cit., s. 291, 364; A. Przy bośs, Garwaski Piotr, [w:] PSB, t. VII, s. 291; informacje dr H. Żerek-Kleszcz na podstawie: AGAD, Orłowskie ziemskie, ks. 49, k. 71. Dodajmy, że M.J. Minakowski określa daty życia P. Garwaskiego na lata 1590-1636. Uważa go jednak za wnuka wymyślonej przez siebie Ewy Elżbiety Kucieńskiej. W związku z powyższym cały jego wywód przodków jest kompletnie chybiony. Brak tu również jakiejkolwiek informacji o żonie Pawła - mimo że małżeństwo to zostało przecież odnotowane przez W. Dworzaczka. Por. Paweł Garwaski z Garwarza h. Grzymała (odm.), (ID: 5.959.28), [w:] WGM, dostęp: 23 X 2015 r. 
wińskich. O jego młodości i wykształceniu brakuje wiadomości. Na scenie publicznej pojawił się stosunkowo późno, bo w końcu drugiego dziesięciolecia XVII w. Od 1618 r. brał żywy udział w życiu politycznym województwa łęczyckiego, gdzie cieszył się spora popularnością. Wielokrotnie był wybierany marszałkiem miejscowego sejmiku: w roku 1618, 1620, 1621, 1628, 1632 i 1635 (dwukrotnie). Posłował też $z$ województwa łęczyckiego na liczne sejmy: $1618,1621,1628,1629,1633,1635,1638,1641$ i 1648 r. W roku 1624 został wybrany posłem $z$ ziemi gostynińskiej. Na sejmach 1629 oraz 1638 r. powoływano go jako reprezentanta województwa łęczyckiego do grona deputatów na trybunał radomski. W czasie bezkrólewia 1648 r. został z kolei deputatem $z$ prowincji wielkopolskiej do rewizji skarbu koronnego. Od roku 1620 był dworzaninem królewskim i $z$ tym tytułem figurował w konstytucjach sejmowych (w księgach grodzkich łęczyckich $z$ tytułem dworzanina SRM odnotowywano go w latach 1625-1643). Garwaski był człowiekiem zamożnym. W 1623 r. w dziale dóbr po ojcu wziął wsie Gołębiewko i Ryków w ziemi gostynińskiej, Ocice Wielkie i Ocice Małe w województwie łęczyckim oraz połowę borów soleckich. W tym samym roku odkupił od swoich siostrzeńców - Stanisława i Jana Szamowskich - wieś Gnojno w ziemi gostynińskiej. Z działu przyrodniego brata Zygmunta przejął też $z$ czasem Podczachy Wielkie i Małe. W 1643 r. kupił część Rokitnicy w parafii Stryków w województwie łęczyckim. Po śmierci brata Pawła, podczaszego gostynińskiego, wszedł $z$ kolei $w$ posiadanie Kutna i części wsi Dudki. Pod koniec życia był właścicielem połowy miasta, 7 wsi całych i 2 części wsi. Jego sytuację materialną w znaczący sposób poprawiło pierwsze małżeństwo. Około 1620 r. poślubił on bowiem Agnieszkę ze Słupskich, wdowę po Marcinie Tarnowskim h. Rola, chorą̇ym mniejszym łęczyckim, zmarłym przed 18 lutego $1617 \mathrm{r}$. Miała ona prawo do dożywotniego użytkowania przejętych po pierwszym mężu wsi królewskich Rzeczyca, Sadykierz, Bobrowiec $\mathrm{i}$ Łag (wydzielonych $z$ tenuty inowłodzkiej). W 1624 r. Garwaski uzyskał ius communicativum na te dobra domeny (od tej pory tytułował się starosta rzeczyckim) i zatrzymał je w swoim ręku po śmierci Agnieszki, która zmarła przed 27 czerwca 1625 r. Druga żona Piotra Garwaskiego została Katarzyna Sienieńska h. Dębno, córka Zbigniewa, kasztelana lubelskiego, i prawdopodobnie jego pierwszej małżonki, Anny Leńkówny z Rokitnicy h. Rawicz, kasztelanki derpskiej (dorpackiej). Żonie tej oprawił posag i wiano na wsiach Gołębiewko i Ryków. W 1636 r. małżonkowie Piotr i Kata- 
rzyna Garwascy otrzymali konsens królewski na ustapienie Rzeczycy niejakiemu Rudzkiemu. Nie wydaje się jednak, by transakcja ta została zrealizowana. W związku $z$ jakimiś rozliczeniami rodzinnymi (być może wówczas odprzedał tenutę rzeczycka, na której Katarzyna miała prawo wspólności) w 1649 r. Garwaski zapisał żonie 22000 florenów na swoich dobrach. W literaturze przedmiotu pojawia się informacja, że Piotr Garwaski zmarł po 1649 r. Nie żył już na pewno 7 czerwca 1660 r., kiedy w aktach grodzkich łęczyckich wspomniany został jako zmarły. $Z$ małżeństwa $z$ Katarzyna z Sienieńskich pozostawił synów Krzysztofa i Ludwika oraz córki Annę, żonę Ludwika Komorowskiego (zm. p. 1714), i Ewę Cecylię, która wyszła najpierw za Jana Kazimierza Szczawińskiego h. Prawdzic, sędziego grodzkiego radziejowskiego (prawnuka Pawła, kasztelana łęczyckiego), a następnie za Franciszka Sokołowskiego ${ }^{42}$.

42 Por. B o n i e cki, Herbarz, t. V, s. 379; N i e s i e cki, Herbarz, t. IV, s. 77; Urus ki, Herbarz, t. IV, s. 103; A. Przy bo ś, Garwaski Piotr, s. 291 (tu błędna informacja, że Garwaski pochodził $z$ rodziny osiadłej $\mathrm{w}$ ziemi ciechanowskiej); J. Choińska-Mika, op. cit., s. 183; E. O paliński, op. cit., s. 291, 364 (tu błędna informacja, że Piotr Garwaski był starosta rzeczyckim w latach 16361649); Vol. leg., t. III, Petersburg 1859, s. 312, 447; t. IV, s. 78; Urzędnicy łęczyccy, nr 221, s. 51; K. Chła powski, A. D un in-W a s owicz, Przynależność własnościowa osiedli. Aneks I: Dobra królewskie w końcu XVI wieku, [w:] Atlas historyczny Polski. Województwo sieradzkie i województwo łęczyckie $w$ drugiej połowie XVI wieku, red. H. Rutkowski, cz. 2 (Komentarz, indeksy), Warszawa 1998, s. 65; H. G mite r e k, Sienieński Zbigniew, [w:] PSB, t. XXVII, WarszawaKraków 1996, s. 194 (tu jednak błędne stwierdzenie, że jedyną żoną Sienieńskiego była poślubiona w 1620 r. Krystyna Uhrowiecka h. Suchekomnaty oraz zdawkowa tylko informacja, że pozostawił on po sobie dwie córki. W moim przekonaniu obie pochodziły z pierwszego małżeństwa swojego ojca); W. M ajews ki, Leniek Maciej, [w:] PSB, t. XVII, Wrocław-Warszawa-Kraków 1972, s. 52-53 (tu niezbyt ścisła informacja, że jedyna córka Macieja Leńka $z$ Rokitnicy i jego żony, Teodory Sapieżanki - Anna - poślubiła kasztelana lubelskiego Zbigniewa Sienieńskiego. Ten ostatni został bowiem kasztelanem lubelskim dopiero 1 IV 1630 r., więc już po śmierci Anny Leńkówny); BKPAN, TD, Grodzkie i ziemskie, Wschowa, część 1, 4511 (Nr. 77 IX), 1714, f. 68 (wspomniano tu o Piotrze Komorowskim, synu nieżyjącego już Ludwika i Anny $z$ Garwaskich); informacje dr H. Żerek-Kleszcz na podstawie: AGAD, ŁGI, ks. 147, k. 495v; ks. 216, k. 104-106; ks. 224, k. 158v. Dodajmy, że M.J. Minakowski określa daty życia Piotra Garwaskiego na lata 1600-1649. Czyni go jednak, podobnie jak jego brata Pawła, wnukiem wymyślonej przez siebie Ewy Elżbiety Kucieńskiej ( $z$ wszystkimi konsekwencjami tej mistyfikacji). Autor ten nie zna również rzecz jasna żadnego $z$ dzieci Piotra Garwaskiego. Por. Piotr Garwaski z Garwarza h. Grzymała (odm), (ID: 5.959.27), [w:] WGM, dostęp: 23 X 2015 r. 
Mikołaj Garwaski (zm. p. 1634) był zapewne najmłodszym synem starosty gostynińskiego Jerzego i Agnieszki ze Szczawińskich. Wstapił do zakonu jezuitów. W latach 1616-1623 wystapił w kilku transakcjach majątkowych swojej najbliższej rodziny. Zmarł zapewne przed $1634 \mathrm{r}$.

Niewiele więcej możemy też powiedzieć o Janie Garwaskim (zm. 1633), starszym synu starosty gostynińskiego $z$ jego drugiego małżeństwa $z$ Anną Tarnowską. Przeznaczony do kariery kościelnej, bardzo szybko, bo już w roku 1618 został kustoszem łowickim po rezygnacji $z$ tej prałatury złożonej przez najstarszego $z$ braci - Stanisława. W 1622 r. Jan Garwaski został także kanonikiem płockim. W 1623 r., po podziale majątku ojcowskiego, obją jeden $z$ działów w imieniu własnym oraz młodszego, nieletniego wówczas brata Zygmunta. W kolejnych latach nie otrzymał żadnego nowego beneficjum. Zmarł już w 1633 r., w wieku około 30 lat ${ }^{43}$.

Szóstym i najmłodszym synem starosty gostynińskiego Jerzego Garwaskiego był Zygmunt (zm. p. 1652). Jego matka była kasztelanka sochaczewska Anna Tarnowska h. Rola. W 1623 r., kiedy bracia Garwascy dokonywali podziału majatku po jego ojcu, był on jeszcze małoletni. Przypadły mu wówczas w udziale (wspólnie $z$ rodzonym bratem Janem) wsie Gnojenko $z$ młynem i folwarkiem, Ruszków z młynem i Raszewo w ziemi gostynińskiej oraz Podczachy Wielkie, Podczachy Małe (Podczaski) i Rusinki (Rusinówek) w województwie łęczyckim. W 1632 r. wziął udział w elekcji Władysława IV, składając swój podpis (obok starszego, przyrodniego brata Pawła) $z$ innymi elektorami z ziemi gostynińskiej. W 1633 r., po śmierci rodzonego brata Jana, przeją $\mathrm{w}$ samodzielne posiadanie cały spadek po ojcu. Wsie Podczachy Wielkie oraz Podczachy Małe odprzedał jednak bratu Piotrowi. Żona Zygmunta Garwaskiego została Ewa Kucieńska h. Ogończyk, córka Jerzego (zm. p. 1636) i Elżbiety Krasińskiej, wojewodzianki płockiej. Pochodziła ona $z$ tej linii Kucieńskich, która władała m.in. połową miasta Kutna (nabył ją od Gosławskich jej dziadek, podkomorzy gostyniński Stanisław

43 Por. AGAD, ŁGI 146, k. 331-334v; Nie s i e cki, Herbarz, t. IV, s. 77 (tu występujący w 1611 r. ksiądz Mikołaj Garwaski, słusznie nazwany synowcem Stanisława, kasztelana płockiego); U ruski, Herbarz, t. IV, s. 103 (tu ksiądz Mikołaj, odnotowany jakoby w 1589 r. i uznany za syna kasztelana płockiego Stanisława); Wywody kanoników płockich, kanonik Jan Garwaski, poz. 6, 1622, sygn. 9, k. 365; E. O p a liń s ki, op. cit., s. 291, 364 (tu kanonik płocki Jan, syn Jerzego, został pomylony $z$ Janem, synem Pawła Garwaskiego); informacje dr H. Żerek-Kleszcz na podstawie: AGAD, ŁGI, ks. 165, k. 2v-3. 
Kucieński, zmarły w 1616 r.). Być może w wyniku rozliczeń z rodziną żony, albo też droga kupna, wszedł Zygmunt w posiadanie wsi Nowe oraz Wilkowia w województwie łęczyckim (pod koniec XVI w. obie wioski stanowiły dziedzictwo Kucieńskich). Nie jest znana dokładna data śmierci Zygmunta Garwaskiego. W 1652 r. Jerzy Kucieński ( $z$ linii na Łąkoszynie) przejął od jego żony - Ewy z Kucieńskich Garwaskiej - trzymana przez nia w posesji zastawnej wieś Kotliska Wielkie $z$ młynem Raczyki, a ona skwitowała kuzyna z sumy zastawu, czyli 4500 złotych. Garwaska przeprowadziła tę transakcję w towarzystwie rodzonych braci, starościców kruszwickich Mikołaja i Andrzeja Władysława. Można przypuszczać, że Zygmunt Garwaski w tym czasie już nie żył. Jedynym znanym synem Zygmunta i Ewy z Kucieńskich był Franciszek Jan Garwaski (zm. po 1699), o którym wiemy niestety stosunkowo niewiele. Według Adama Bonieckiego sprawował on urząd stolnika inowrocławskiego. W spisach urzędników kujawskich i dobrzyńskich nie został jednak odnotowany. Najpewniej wyprzedał dobra po rodzicach na pograniczu województwa łęczyckiego i ziemi gostynińskiej i następnie przeniósł się do województwa mazowieckiego ${ }^{44}$.

44 Por. AGAD, ŁGI 146, k. 331-334v; 201, k. 274v; W. Ka c zorow s ki, P. Dydyński, op. cit., s. 303; M. Kobie recki, op. cit., s. 177-179, 211; U ruski, Herbarz, t. V, s. 103 (tu bałamutna informacja, że Zygmunt Garwaski był synem podczaszego gostynińskiego Pawła); B o n i e c ki, Herbarz, t. V, s. 379 (tu Zygmunt w ogóle nie został odnotowany; Franciszek Jan, stolnik inowrocławski, w 1688 r. sprzedać miał natomiast któremuś z Krasińskich wieś Małachówko - nazwa zapewne przekręcona - najpewniej w województwie mazowieckim, gdyż transakcja ta została wpisana do ksiag grodu warszawskiego); Urzędnicy kujawscy, s. 112 (wśród stolników inowrocławskich $z$ drugiej połowy XVII w. brak nazwiska Franciszka Jana Garwaskiego); informacje dr H. Żerek-Kleszcz na podstawie: AGAD, ŁGI, ks. 166, k. 175v-176v; Materiały do dziejów ziemi płockiej, t. VI (Ziemia makowska), wyd. M.M. Grzybowski, Płock 1991, s. 153-154, 163-164 (tu informacja, że Franciszek Jan Garwaski, stolnik inowrocławski, był administratorem klucza węgrowskiego na Podlasiu należącego w owym czasie do wojewody płockiego Bonawentury Krasińskiego i 15 VII 1699 r. napisał list ze Starej Wsi do wojskiej nurskiej Marianny z Radzimińskich Brzezińskiej). Dodajmy w tym miejscu, że jest wielce prawdopodobne, iż synem Franciszka Jana był Franciszek Kazimierz Garwaski, czynny w pierwszej ćwierci XVIII w. w województwach mazowieckim i podlaskim miecznik (od 1700 r.), a być może również i choraży (od 1720 r.) gostyniński. Por. U r u s ki, Herbarz, t. V, s. 104; B o n i e c ki, Herbarz, t. IV, s. 379 (tu raczej nieprawdziwa informacja, że ojcem Franciszka Kazimierza był nieznany skądinąd Mikołaj Garwaski); T. J a s z c z ołt, Lista dobrodziejów klasztoru franciszkanów w Drohiczynie z lat 1678-1783, [w:] Małe miasta. Zabytki, red. M. Zemło, R. Dobrowolski, Lublin-Supraśl 2009, s. 154 (tu wzmianka, że w sierpniu 1711 r. Franciszek Kazimierz Garwaski, miecznik gostyniński, daro- 
Krzysztof (zm. po 1699) i Ludwik (zm. p. 1689) Garwascy byli synami Piotra, dworzanina królewskiego i tenutariusza rzeczyckiego, oraz Katarzyny Sienieńskiej. W 1667 r. bracia wspólnie zastawili należąca do nich część Kutna Andrzejowi Władysławowi Kucieńskiemu, właścicielowi drugiej połowy tego miasta. O młodszym $z$ braci - Ludwiku - wiemy jedynie, że zmarł bezpotomnie przed 1689 r. Zdecydowanie więcej możemy powiedzieć o Krzysztofie. W 1661 r. zapisał on pewna sumę swojej siostrze Ewie Cecylii, zamężnej później z Janem Kazimierzem Szczawińskim, a następnie z Franciszkiem Sokołowskim. W 1674 r. Krzysztof Garwaski podpisał $z$ województwem łęczyckim wybór Jana III Sobieskiego. Był właścicielem sporego majątku. Przed rokiem 1679 sprzedał jednak Podczachy Wielkie, Podczachy Małe (Podczaski) i Rusinki (Rusinówek) biskupowi sufraganowi gnieźnieńskiemu Wojciechowi Stawowskiemu. W 1682 r. odnotowano go $z$ tytułem miecznika gostynińskiego, nie jest jednak pewne, czy urzad ten faktycznie sprawował. W jego posiadaniu, oprócz miasta Kutna, znajdowały się wówczas również stare posiadłości rodowe, więc wsie Gnojenko, Raszewo i Ocice. Miał także prawa do dóbr Gole i Stróże w powiecie przedeckim (województwo brzeskie-kujawskie). W 1689 r. Krzysztof Garwaski powiększył swoje dobra, nabywając części we wsiach Krzesino (Krzeszyno), Krzesinek i Borski, czyli Skłoty w województwie łęczyckim. W październiku 1693 r. został wybrany deputatem $z$ województwa rawskiego na Trybunał Koronny (nie tytułowano go już jednak wówczas miecznikiem gostynińskim). Żoną Garwaskiego została Katarzyna Walewska h. Kolumna, córka Zygmunta, podkomorzego łęczyckiego, i Agnieszki z Plichtów h. Półkozic. Mał-

wał drohickim franciszkanom 3 złote na wosk). Warto też słów kilka poświęcić żonie Zygmunta Garwaskiego - Ewie Kucieńskiej. M.J. Minakowski, wbrew wszelkiej logice i $z$ naruszeniem zasad naukowej rzetelności, nazywa ją Ewą Elżbieta, datuje jej urodzenie na rok 1530 i podaje, że była ona matka Jerzego Garwaskiego, starosty gostynińskiego, i babka jego synów: Pawła, Piotra i Jana. Por. Ewa Elżbieta Kucieńska $z$ Kutna h. Ogończyk (ID: 13.191.114), [w:] WGM, dostęp: 23 X 2015 r. W rzeczywistości Ewa Kucieńska urodziła się około 1610 r. jako córka Jerzego (zm. p. 1636), starosty kruszwickiego, i Elżbiety Krasińskiej, wojewodzianki płockiej (zm. po 1645), a wnuczka Stanisława Kucieńskiego (zm. 1616), podkomorzego gostynińskiego, Ewy de Wedel Frydlandzkiej (zm. p. 1617), Stanisława Krasińskiego (zm. 1617), wojewody płockiego, i zapewne jego pierwszej żony, Małgorzaty ze Staroźreb Sobiejuskiej (zm. p. 1590). Por. BKPAN, TD, Grodzkie i ziemskie, Wałcz, 547 (Nr. 26) 1617, f. 146v; J. M a c is z e w s k i, Krasiński Stanisław, [w:] PSB, t. XV, Wrocław-Warszawa-Kraków 1970, s. 191-192; W. D w o r z a c z e k, Genealogia, t. II, tabl. 136. 
żeństwo to zostało zawarte w połowie lat osiemdziesiątych XVII w. Nie jest znana wysokość posagu, jaki miała otrzymać podkomorzanka łęczycka. Wiadomo jednak, że brat Konstanty przekazał jej sumę 12000 złotych, darowaną Walewskim na mocy zapisu testamentowego przez arcybiskupa gnieźnieńskiego Stefana Jana Wydżgę. Po otrzymaniu tej kwoty 12 września 1686 r. Katarzyna z Walewskich Garwaska zrzekła się z mężem wszelkich pretensji do dóbr po rodzicach. W kolejnych latach sytuacja majattkowa Krzysztofa Garwaskiego uległa znacznemu pogorszeniu. W rezultacie został zmuszony do sprzedaży dóbr kutnowskich. W $1698 \mathrm{r}$. Anna Franciszka $z$ Gnińskich Zamoyska, wdowa po Marcinie, podskarbim wielkim koronnym, kupiła od Garwaskiego połowę Kutna z przyległościami za 50000 złotych. Przedmiotem transakcji, oprócz połowy miasta, były dwie części Walentynowa, czyli dawne wsie Raszewo i Gnojenko oraz Atle (wieś pusta), Dudki i karczma w Dybowie, wszystko w powiecie gostynińskim, jak również część wsi Piaski, wieś Ocice i część w Krzesinie (Krzeszynie) w województwie łęczyckim. Zamoyska kupiła także od Garwaskiego wieś Klonowa, której położenia nie udało się ustalić. Nowa właścicielka dóbr kutnowskich, która już w 1689 r. nabyła druga połowę Kutna od Zofii ze Słoniewskich, wdowy po kasztelanie gostynińskim Andrzeju Władysławie Kucieńskim, otrzymała również, przysługujace do tej pory Garwaskim, prawo do opieki nad szpitalem przy kościele parafialnym oraz zwierzchność nad znajdującym się w tymże kościele ołtarzem św. Rozalii. Warto zaznaczyć, że Zamoyska wypłaciła Garwaskiemu jedynie 5000 złotych (z takiej sumy została skwitowana). Reszta należności miała być przeznaczona na uregulowanie starych długów poprzedniego właściciela, których spłatę wzięła na siebie podskarbina wielka koronna. Przy okazji opisanej tu transakcji Katarzyna $z$ Walewskich Garwaska zrezygnowała ze swojej oprawy i dożywocia na kluczu kutnowskim, a mąż zabezpieczył jej posag i wiano na innych swoich dobrach (najpewniej w powiecie przedeckim). W 1699 r. Katarzyna Garwaska zmarła. Krzysztof przeżył swoja małżonkę, ale data jego śmierci jest nieznana. Po sprzedaży dóbr kutnowskich Garwascy $z$ tej linii rodu w sposób nagły i ostateczny utracili swoją dotychczasowa pozycję. Synowie Krzysztofa i Katarzyny nie dysponowali już ani majątkiem, ani wpływami, które pozwoliłyby im wznieść się ponad po- 
ziom średnioszlachecki. W następnych pokoleniach kryzys rodziny miał się zreszta jeszcze pogłębić 45 .

$\mathrm{Na}$ zakończenie rozważań wypada dodać jeszcze kilka słów ostatecznego podsumowania. $\mathrm{Na}$ podstawie przeprowadzonych badań możemy jednoznacznie stwierdzić, że Garwascy h. Grzymała to stara rodzina mazowiecka o udokumentowanym rodowodzie sięgającym przełomu XIII i XIV w. Żyjący w XV stuleciu przodkowie późniejszych Garwaskich, piszący się z Miszewa i stąd nazywani Miszewskimi, podobnie jak ich przodek - kasztelan wyszogrodzki Mikołaj, odbiorca nadania księcia Wańka z 1319 r. - należeli do grona mazowieckiego możnowładztwa. Uwaga ta dotyczy Filipa z Miszewa (zm. 1442), podczaszego płockiego, oraz jego jedynego syna - kasztelana wiskiego Jana (zm. 1471). Po śmierci tego ostatniego, w związku $z$ podziałem zgromadzonego przez niego majątku na trzy schedy, rodzina straciła przejściowo swoje dotychczasowe znaczenie. Żaden $z$ synów kasztelana nie piastował mazowieckich czy też koronnych urzędów. Dopiero jeden $z$ jego wnuków - Jan

45 Por. AGAD, ŁGI 238, k. 97v-98v; 270, k. 71; 273, k. 210; 274, k. 336-337; 279, k. 266-266v; 280, k. 476; B on i e cki, Herbarz, t. V, s. 379; N i e s i e cki, Herbarz, t. IV, s. 77; U ru s k i, Herbarz, t. V, s. 104 (z błędami); M. K o b i e r e c k i, op. cit., s. 177-179, 180-181; id e m, Walewscy herbu Kolumna w XVII-XVIII wieku. Genealogia. Majętności. Działalność polityczna, Łódź 2008, s. 232-233 (tu informacja, że matka Katarzyny Walewskiej była druga żona podkomorzego Zygmunta - Helena $z$ Tarnowskich. W moim przekonaniu jest jednak mało prawdopodobne, aby Katarzyna $z$ Walewskich Garwaska urodziła się przed 1655 r., kiedy żoną Zygmunta Walewskiego była już Agnieszka Plichcianka); informacje dr H. Żerek-Kleszcz na podstawie: AGAD, ŁGI, ks. 262, k. 91v-92; ks. 281, k. 268269; ks. 291, k. 339. Dodajmy w tym miejscu, że Krzysztof Garwaski pozostawił z Katarzyny Walewskiej trzech synów: Jana, Piotra i Krzysztofa, którzy odziedziczyli dobra ojcowskie na Kujawach i w 1718 r. zawarli między soba układ w grodzie przedeckim. O Piotrze i Krzysztofie nic więcej nie wiadomo. Natomiast Jan ożenił się przed 1713 r. z Zofią Kwilecka h. Szreniawa, córka Jana i Katarzyny Błociszewskiej h. Ostoja, i objął jakieś dobra w Wielkopolsce właściwej. Oboje zmarli przed 1726 r. Ich synem był Norbert Garwaski (zm. po 1745), który w 1730 r. „zrzekł się fortuny po ojcu dla ratowania fortuny po matce”. Por. B o n i e cki, Herbarz, t. V, s. 379 (tu watpliwa informacja, że Jan Garwaski - urodzony najwcześniej w połowie lat osiemdziesiatych XVII w. - podpisał w $1697 \mathrm{r}$. elekcję Augusta II oraz błędne stwierdzenie, że zapisał on żonie pewna sumę w 1728 r.); U r u s k i, Herbarz, t. IV, s. 104 (tu powtórzona za Bonieckim wątpliwa informacja o udziale Jana Garwaskiego w elekcji Augusta II oraz zgodna z prawda wzmianka o Norbercie, synu Jana); BKPAN, TD, Grodzkie i ziemskie, Konin, 12304 (Nr. 73), 1713, f. 237; 12684 (Nr. 75), 1720, f. 204; 13184 (Nr. 76), 1730, f. 338; 13968, (Nr. 77), 1745, f. 412v; Zap. Tryb. Piotrk., 891 (Nr. 45), 1726, f. 452 . 
Miszewski z Garwarza, czyli Jan Garwaski z Miszewa (zm. 1540) dziedziczaccy dobra po ojcu i jednym ze stryjów, zdołał odbudować zarówno pozycję majątkowa, jak i polityczną rodu. Sięgnął też po urzędy stolnika wyszogrodzkiego i cześnika płockiego. Przełomowym wydarzeniem w dziejach omawianego rodu było jednak małżeństwo zawarte przez Jana Garwaskiego z Zofia Dzierzgowska, siostra prymasa Mikołaja Dzierzgowskiego (zm. 1559). Synowie wspomnianej pary - Paweł (zm. 1560) i Hieronim (zm. 1583) - mogli liczyć na protekcję i wsparcie ze strony potężnego wuja. Pierwszy $z$ nich został kasztelanem sierpskim, drugi kanclerzem gnieźnieńskim, kumulującym w swoim ręku 8 różnych prałatur. Być może przedwczesna śmierć przeszkodziła Pawłowi Garwaskiemu w osiągnięciu wyższego miejsca w senacie, a śmierć arcybiskupa zamknęła jego bratu drogę do sakry biskupiej. Paweł Garwaski jednak, podobnie jak ojciec, też zawarł bardzo korzystne i prestiżowe małżeństwo, poślubiając Elżbietę Kucieńską, córkę wojewody rawskiego Stanisława (zm. 1542). Dzięki tej koligacji dzieci wspomnianej pary odziedziczyły, po bezpotomnej śmierci wszystkich synów wojewody Stanisława, trzecią część dóbr kutnowskich. To właśnie synowie Pawła i Elżbiety z Kutna - Stanisław, Paweł i Jerzy - doprowadzili ród Garwaskich do największego znaczenia, a apogeum jego świetności przypadło na czasy panowania Zygmunta III. Stanisław (zm. 1613) i Paweł (zm. 1618) Garwascy osiagnęli kolejno godność kasztelana płockiego. Ich najmłodszy brat Jerzy (zm. $1615 / 1616)$ był $z$ kolei starosta gostynińskim. W chwili śmierci kasztelana płockiego Stanisława dobra ziemskie Garwaskich położone w województwach płockim, mazowieckim, rawskim, łęczyckim oraz w ziemi dobrzyńskiej obejmowały 1 miasto całe, 1 część miasta, 1 wójtostwo, 19 wsi całych i 2 części wsi. Ponadto użytkowali oni dwie spore i dość zamożne królewszczyzny - starostwa gostynińskie (zamek, miasto i 5 wsi) oraz wyszogrodzkie (zamek, miasto i 7 wsi). Jerzy Garwaski nie zdołał jednak przekazać starostwa gostynińskiego któremuś ze swoich synów, a Paweł zmuszony był odprzedać starostwo wyszogrodzkie Karnkowskim. Po śmierci Pawła w 1618 r. Garwascy utracili też status rodziny senatorskiej. $\mathrm{W}$ następnych pokoleniach już żaden $z$ nich nie zasiadł $\mathrm{w}$ senacie. Obaj synowie Pawła zmarli bezpotomnie, a ich dobra przeszły w posiadanie kasztelana płockiego Walentego Zielińskiego. Spośród sześciu synów Jerzego trzech wybrało karierę duchowną. Stanisław (zm. 1635) został dziekanem płockim i kanonikiem krakowskim, Jan (zm. 1633) kustoszem łowickim i kanonikiem płockim, 
a Mikołaj (zm. p. 1634) wstapił do zakonu jezuitów. $Z$ pozostałych Paweł (zm. p. 1654) był podczaszym gostynińskim, Piotr (zm. p. 1660) dworzaninem królewskim i dzierżawca rzeczyckim, a Zygmunt (zm. p. 1652) nie pełnił żadnych urzędów. Najbogatszym $z$ braci był Piotr, który pod koniec życia posiadał połowę miasta Kutna, 7 wsi całych i 2 części wsi. Dobra te przekazał synom: Krzysztofowi (zm. po 1699) i Ludwikowi (zm. p. 1689). Po bezpotomnej śmierci Ludwika dziedzicem całości majątku ojcowskiego został Krzysztof. Był on ostatnim przedstawicielem rodu, którego można zaliczyć do zamożnej szlachty. Status ten utracił po dokonanej w 1698 r. sprzedaży dóbr kutnowskich. Jego potomkowie żyjący w XVIII stuleciu nie wyrośli już nigdy ponad poziom średnioszlachecki. Podobny los przypadł w udziale synowi Zygmunta Garwaskiego - Franciszkowi Janowi (zm. po 1699), który wyprzedał dobra rodowe na pograniczu województwa łęczyckiego i ziemi gostynińskiej, a następnie przeniósł się do województwa mazowieckiego 46 .

Warto też odnotować, że niemal do końca XVII w. Garwascy wiazali się ze znanymi i zamożnymi rodzinami senatorskimi. Paweł (zm. 1618) poślubił Dorotę Zielińską, córkę Grzegorza, wojewody płockiego. Jego brat Jerzy (zm. 1615/1616) ożenił się najpierw z Agnieszką Szczawińska, a następnie z Anną Tarnowską, córka kasztelana sochaczewskiego Stanisława. Jeden $z$ synów Pawła Jan (zm. 1624) - poślubił Izabelę Karnkowską, córkę wojewody płockiego Jana Stanisława. Z synów Jerzego: Paweł ożenił się z Anną Krasińska, córką Franciszka, kasztelana ciechanowskiego; Piotr żenił się dwukrotnie, najpierw $z$ Agnieszką Słupska, a następnie $z$ Katarzyną Sienieńska, córką Zbigniewa, kasztelana lubelskiego; Zygmunt zaś poślubił Ewę Kucieńską, córkę Jerzego, starosty kruszwickiego. Dodajmy również, że jedyny żonaty syn Piotra i Katarzyny Sienieńskiej - Krzysztof - zawarł związek małżeński $z$ Katarzyną Walewska, córką Zygmunta, podkomorzego łęczyckiego. Dość będzie powiedzieć w uzupełnieniu tego wywodu, że synowie starosty gostynińskiego Jerzego Garwaskiego byli spowinowaceni $z$ tak znanymi i wpływowymi rodzinami, jak Krasińscy, Kretkowscy, Sierakowscy, Sienieńscy, Lanckorońscy, Walewscy,

46 Warto w tym miejscu przywołać też dla porównania, nie do końca zgodne ze stanem faktycznym, uwagi dotyczace kariery rodu Garwaskich sformułowane przez badacza elity senatorskiej prowincji wielkopolskiej w czasach panowania Zygmunta III. Por. E. O p a li ń s k i, op. cit., s. 13, 28, 47, 102, 289, 291. 
Konarscy, Plichtowie czy wreszcie Leszczyńscy47. Dzięki tym koligacjom Garwascy, którzy po 1618 r. nie zasiadali już w senacie, niemal przez całe XVII stulecie potrafili utrzymać swoje miejsce wśród rodzin zaliczanych do szeroko pojętej elity polityczno-majątkowej prowincji wielkopolskiej. Sprzedaż dóbr kutnowskich w 1698 r. spowodowała jednak gwałtowne pogorszenie sytuacji majątkowej rodziny i oznaczała definitywna utrate jej dotychczasowej pozycji i znaczenia.

\section{The Garwaski family, Grzymała coat of arms, in the $15^{\text {th }}-17^{\text {th }}$ century. Contribution to the history and genealogy of the family}

The aim of the study was to complete the genealogy of the Garwaski family and its achievements in the $15^{\text {th }}, 16^{\text {th }}, 17^{\text {th }}$ century and present the most prominent representatives of the family. The survey showed that the Garwaski family, Grzymała coat of arms, is an old family from Mazovia, the genealogy of which is dated back to the $13^{\text {th }}$ and $14^{\text {th }}$ century. The $15^{\text {th }}$-century ancestors of the later Garwaski family were from Miszewo and hence they were called the Miszewski family. They were the lords of Mazovia, as well as their ancestor, Mikołaj, the castellan of Wyszogród who received his title from the prince Wańko (Wacław) in 1319. This also applies to Filip from Miszewo (d. 1442), the cupbearer (podczaszy) of Płock, and his only son, Jan, the castellan of Wizna (d. 1471). After the death of the latter the family had to divide its inheritance into three parts and thus temporarily lost its previous importance. None of the castellan's children was an official. Only one of his grandsons, Jan Miszewski from Garwarz, also called Jan Garwaski from Miszewo (d. 1540), managed to both regain his family political position and rebuild its finance as he inherited landed estates from his

47 Podobną uwagę w odniesieniu do małżeństw zawieranych przez Garwaskich sformułował E. O paliński: „Zaskakujaco dobrze wypadly natomiast mariaże Garwaskich. Wszystkie znane nam wypadki dotyczyły związków z rodzinami wielkosenatorskimi na Mazowszu. I tak Jan, cześnik płocki (1531), poślubił Zofię Dzierzgowską; Paweł, kasztelan sierpski (1553-1560) - Kucieńską, a syn Pawła, również Paweł, późniejszy kasztelan płocki - Dorotę Zielińska, córkę Grzegorza, wojewody płockiego". Por. i d e m, op. cit., s. 79. 
father and uncle who died childless. He was the pantler (stolnik) of Wyszogród and cupbearer (cześnik) of Płock. Jan Garwaski married Zofia Dzierzgowska who was a sister of the primate Mikołaj Dzierzgowski (d. 1559). That marriage was one of the most important events in the history of the Garwaski family. Their sons, Pawel (d. 1560) and Hieronim (d. 1583), could count on the patronage and support of the powerful uncle. The first was the castellan of Sierpc, the second, the chancellor of Gniezno who governed 8 different prelatures. Pawel Garwaski could have probably gained higher position in the Senate but he died untimely. Perhaps his brother could have become a bishop, if only the archbishop Dzierzgowski had lived any longer. Yet, Paweł Garwaski, like his own father, had a wife from the wealthy and prominent family. He married Elżbieta Kucieńska, a daughter of Stanisław, the voivode of Rawa (d. 1542). Their children inherited, after the childless deaths of all Stanisław's sons, a third part of the landed estate of Kutno. The sons of Paweł and Elżbieta from Kutno, Stanisław, Paweł and Jerzy, made the Garwaski family prominent. The reign of king Sigismund III Vasa was the best time for the family. Both Stanisław (d. 1613) and Paweł (d. 1618) Garwaski were the castellans of Plock. Their youngest brother, Jerzy (d. 1615/16), was the governor (starosta) of Gostynin. When Stanisław, the castellan of Płock, died the Garwaski family had in its possession landed estates located in voivodeship of Płock, Mazovia, Rawa, Łęczyca and land of Dobrzyń that included one town, one part of a town, one aldermanship (wójtostwo), 19 villages and two parts of a village. They also made the use of two quite wealthy Royal estates, the crown land (starostwo) of Gostynin (the castle, the town and 5 villages) and crown land (starostwo) of Wyszogród (the castle, the town and 7 villages). However, Jerzy Garwaski was unable to pass the crown land of Gostynin to one of his sons and Pawel was forced to sell the crown land of Wyszogród to the Karnkowski family. After the death of Pawel in 1618 the Garwaski family ceased to be a senatorial one. None of his successors was a senator. Pawel's two sons died childless and their landed estates passed to their uncle the castellan of Płock, Walenty Zielinski. Three of six Jerzy's sons chose a clerical career. Stanisław (d. 1635) was a dean of Płock and a canon of Kraków, Jan (d. 1633), a curator (kustosz) of Łowicz and a canon of Płock, Mikołaj (d. after 1634) joined the Jesuit order. What is more, Pawel (d. before 1654) was a cupbearer (podczaszy) of Gostynin, Piotr (d. before 1660) became the royal courtier and a leaseholder of Rzeczyca crown land and Zygmunt (d. before 1652) did not hold any office at all. Piotr was the richest of the brothers. At the end of his life he had a half of town Kutno, 7 villages and two parts of a village. These estates were inherited by his sons, Krzysztof (d. after 1699) and Ludwik (d. before 1689). When Ludwik died childless, Krzysztof inherited all fortune of their father. He was the last descendant of the family who could be described as a wealthy nobleman. Yet, he lost that status in 1698, when he sold landed estate Kutno. His $18^{\text {th }}$-century descendants were members of the 
middle nobility only. The son of Zygmunt Garwaski, Franciszek Jan (d. after 1698) also sold familial landed estates located on the borderland between Łęczyca voivodeship and Gostynin land (part of Rawa voivodeship) and moved to the Mazovian voivodeship.

It is also worth noting that until the end of the $17^{\text {th }}$ century male representatives of the Garwaski family had wives from well-known and wealthy senatorial families. Paweł (d. 1618) married Dorota Zielińska, a daughter of Grzegorz, the voivode of Płock. His brother, Jerzy (d. 1615/16), married Agnieszka Szczawińska and later Anna Tarnowska, a daughter of Stanisław, the castellan of Sochaczew. One of Paweł's sons, Jan (d. 1624), married Izabela Karnkowska, a daughter of Jan Stanisław, the voivode of Płock. As for Jerzy's sons: Paweł married Anna Krasińska, a daughter of Franciszek, the castellan of Ciechanów; Piotr married Agnieszka Słupska and later Katarzyna Sienieńska, a daughter of Zbigniew, the castellan of Lublin; Zygmunt married Ewa Kucieńska, a daughter of Grzegorz, the governor (starosta) of Kruszwica. Katarzyna Walewska, a daughter of Zygmunt, the chamberlain (podkomorzy) of Łeczyca, was the wife of Krzysztof, the only son of Piotr and Katarzyna Sienieńska who ever married. Finally, sons of Jerzy Garwaski, the governor (starosta) of Gostynin were bound by the family connections with the well-known and influential families such as the Krasiński, Kretkowski, Sierakowski, Sienieński, Lanckoroński, Walewski, Konarski, Plichta and Leszczyński. Thus through almost entire seventeenth century the Garwaski family was still perceived as a part of political and financial elite of Greater Poland. Its financial situation worsened when the family sold Kutno landed estate in 1698. Then the Garwaski family definitively lost its position and importance. 